JULIANA FUJIMOTO

e-mail: julianafujimoto@usp.br

\title{
GUERRA E ANTROPOFAGIA EM JEAN DE LÉRY E CLAUDE D'ABBEVILLE: DOS FRAGMENTOS MÍTICOS AO CÓDIGO COMPARTILHADO
}

Dissertação apresentada à Faculdade de Filosofia, Letras e Ciências Humanas, da Universidade de São Paulo para a obtenção do título de Mestre em História.

Área de concentração: História Social

Orientador: Prof. Dr. Adone Agnolin

São Paulo

2008 


\section{FUJIMOTO, Juliana.}

Guerra e antropofagia em Jean de Léry e Claude d'Abbeville: dos fragmentos míticos ao código compartilhado./ Juliana Fujimoto; orientador Adone Agnolin. São Paulo, 2008.

Dissertação (Mestrado - Programa de Pós-Graduação em Ciências Humanas. Área de Concentração: História Social)

1. Tupinambá; 2. guerra; 3. antropofagia; 4. tradução religiosa; 5. códigos compartilhados; 6. Brasil colonial. 


\section{FOLHA DE APROVAÇÃO}

Juliana Fujimoto

Guerra e antropofagia em Jean de Léry e Claude d'Abbeville: dos fragmentos míticos ao código compartilhado.

Dissertação apresentada à Faculdade de Filosofia, Letras e Ciências Humanas, da Universidade de São Paulo para a obtenção do título de Mestre em História.

Área de concentração: História Social

Orientador: Prof. Dr. Adone Agnolin

Aprovado em:________

Banca Examinadora:

Prof. (a) Dr.(a)

Instituição

Assinatura:

Prof.(a) Dr(a)

Instituição Assinatura: 


\section{RESUMO}

FUJIMOTO, Juliana. Guerra e antropofagia em Jean de Léry e Claude d'Abbeville: dos fragmentos míticos ao código compartilhado. 2008. 117f. Dissertação (Mestrado). Faculdade de Filosofia, Letras e Ciências Humanas, Universidade de São Paulo, São Paulo, 2008.

Os fragmentos míticos tupinambá sobre a origem da guerra presentes nas obras de Jean de Léry e de Claude d'Abbeville constituem fontes privilegiadas para analisarmos tanto a tradução européia da alteridade indígena, a partir do enfoque naqueles que foram classificados dentre os piores costumes indígenas - a guerra e a antropofagia -; quanto uma possível re-fundação nativa da guerra e da antropofagia a partir das novidades conhecidas desde o encontro com a alteridade européia. Isso porque esses registros contêm elementos do cristianismo professado pelos europeus com os quais os nativos tiveram contato, assim como elementos da leitura tupinambá, em termos míticos, da alteridade européia. Nesse sentido, essas narrativas podem ser compreendidas também como códigos construídos e compartilhados por europeus e indígenas desde o encontro entre essas populações. No contexto estudado é a linguagem da religião cristã que constitui o principal instrumento de mediação na comunicação entre europeus (sobretudo, os missionários) e indígenas e de tradução da alteridade americana para a cultura européia. Dessa forma, nesse trabalho, tentaremos analisar os registros de Léry e de d'Abbeville sobre o início das guerras inter-tribais, tendo em vista o fato destes constituírem uma tradução da guerra e da antropofagia indígena para o público europeu, assim como um possível código construído e compartilhado entre indígenas e europeus, no contexto das relações entre franceses e indígenas (Léry) e no contexto da relação entre indígenas e missionários jesuítas (d'Abbeville).

Palavras Chave: Tupinambá, guerra, antropofagia, tradução religiosa, códigos compartilhados, Brasil colonial. 


\section{ABSTRACT}

FUJIMOTO, Juliana. War and anthropophagy according to Jean de Léry e Claude d'Abbeville: from the mythic fragments to the shared codes . 2008. 117f. Dissertation (Master's degree). Faculdade de Filosofia, Letras e Ciências Humanas, Universidade de São Paulo, São Paulo, 2008.

The tupinambá's mythic fragments about the origin of the war related by Jean de Léry and Claude d'Abbeville are good fonts to we analyze so the translation of the Indian, based upon approach in those that were classified between the worst Indian customs - the war and the anthropophagy - ; as a possible re-foundation of these customs, based upon the news which Indians knew since their fist encounter with the European. These registers have elements of the Christianism professed for the Europeans that Indians knew, as elements of the Indian read, in mythic terms, of the other European. In this sense, these narratives can be understood too as a code constructed and shared for Europeans and Indians since the encounter between these people. In this study, the Christian religion language is the main mediation instrument of the communication between Europeans (above all missionaries) and Indians, and the main translation's instrument of the American difference for the European culture. Therefore, in this study, we will try to analyze the Lery's and the d'Abbeville's texts about the origin of the war, considering the fact that theses texts are a translation of the war and of the anthropophagy to the European public, and considering too that these are a possible code shared between Indians and Europeans, into the context of the relationship among Frenchs and Indians (Léry) and into the context of the relationship among Jesuits missionaries and Indians (d'Abbeville).

Key words: Tupinamba, war, anthropophagy, religious translation, shared codes, colonial Brazil. 


\section{SUMÁRIO}

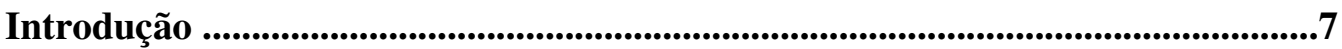

Capítulo 1: A construção do código compartilhado entre europeus e indígenas sobre a guerra e a antropofagia

Interpretações sobre a guerra indígena........................................................13

A presença do outro no mito e no ritual guerreiro...........................................31

Capítulo 2: A guerra e a antropofagia segundo o código construído entre estrangeiros e indígenas na França Antártica

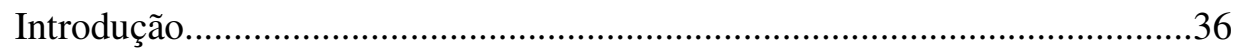

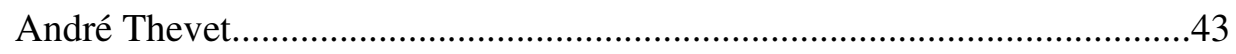

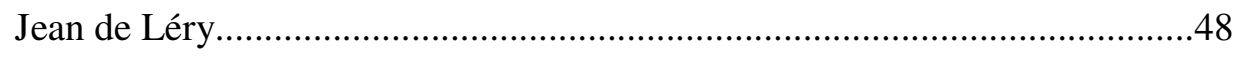

A origem da guerra entre os tupinambá.........................................................59

Capítulo 3: A guerra e a antropofagia segundo o código construído entre estrangeiros e indígenas na França Equinocial

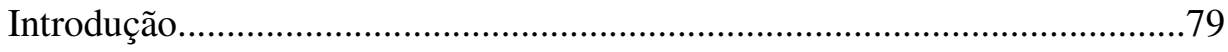

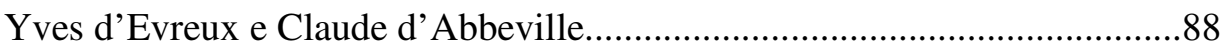

A origem da guerra, segundo os Tupinambá..............................................97

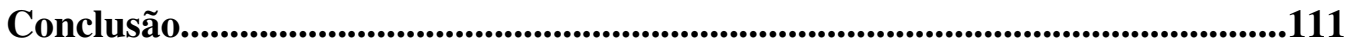

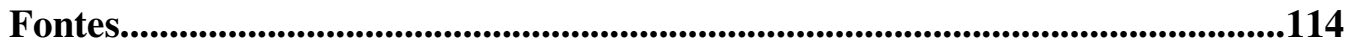

Referências Bibliográficas........................................................................................115 


\section{INTRODUÇÃO}

As narrativas registradas por Jean de Léry ${ }^{1}$ e por Claude d' Abbeville ${ }^{2}$ sobre a origem da guerra entre os Tupinambá constituem fontes privilegiadas para analisarmos a tradução européia da alteridade indígena, assim como uma possível reconstrução indígena da origem das guerras inter-tribais a partir das novidades conhecidas pelos nativos desde o encontro com a alteridade européia. É importante enfatizar, ainda, que, nessas narrativas ganhou destaque o juízo europeu sobre a guerra e a antropofagia, que teve como referência o cristianismo professado pelos europeus com os quais os Tupinambá tiveram contato.

Isso porque, como destacou Pompa, o instrumento privilegiado para a compreensão das culturas americanas foi a religião, já que a maior parte da literatura quinhentista e seiscentista sobre os povos da América provém das cartas e relatos dos missionários de ordens religiosas católicas e protestantes ${ }^{3}$, prevalecendo no caso do Brasil, a ordem da Companhia de Jesus ${ }^{4}$. Os jesuítas que para cá vieram não só compreenderam a cultura indígena por meio do catolicismo ${ }^{5}$, como também se utilizaram deste para se comunicar com os ameríndios e realizar um de seus intentos que era a conversão destes povos. Assim, foi a tradução da alteridade indígena para os europeus e do cristianismo para os indígenas o meio pelo qual se produziu uma cultura do encontro ${ }^{6}$.

$\mathrm{Na}$ tradução da alteridade indígena para os europeus, os relatos sobre as guerras inter-tribais e, principalmente, o seu desfecho - a antropofagia - parecem ter constituído os principais argumentos para se defender uma suposta "irracionalidade" americana, já que os indígenas, ao guerrearem por vingança e ao comerem carne humana, violavam as leis divinas e naturais. Ao passo que, esses costumes, quando pensados em relação ao projeto de evangelização dos americanos, trouxeram dificuldades, já que os religiosos que pensaram a questão da legitimidade da presença

\footnotetext{
${ }^{1}$ LÉRY, Jean de. Viagem à Terra do Brasil. São Paulo: Martins/ Edusp, 1972. p. 168.

2 ABBEVILLE, Claude. História da Missão dos Padres Capuchinhos na Ilha do Maranhão e terras circunvizinhas; em que se trata das singularidades admiráveis e dos costumes estranhos dos índios habitantes do país. São Paulo: Livraria Martins, 1945. p.60-1.

${ }^{3}$ POMPA, Cristina. Religião como tradução: missionários, Tupi e Tapuia no Brasil colonial. BauruSP: EDUSC, 2003. p.25.

${ }^{4}$ Ibidem, P.57.

${ }^{5}$ Estou me referindo a um catolicismo "contextualizado", que teve diversas influências no período estudado, inclusive da situação religiosa européia no momento do encontro.

${ }^{6}$ POMPA, Cristina. Op. Cit. , p.86.
} 
européia na América, assim como os padres em missão entre os indígenas, deveriam explicar como nações que praticavam ações tão bárbaras eram passíveis de conversão.

Como veremos, um dos primeiros estudiosos a pensar nessa questão foi Francisco Vitoria, um dominicano que ocupou a primeira cadeira de teologia na Escola de Salamanca entre 1529 e 1546. Segundo Pagden, antes de Vitoria, os estudos espanhóis sobre os povos americanos foram realizados para atender as solicitações do rei espanhol. Dessa forma, as obras de Vitoria constituíram os primeiros estudos universitários sobre os povos americanos que, por sua vez influenciaram uma série de outros estudos sobre o referido tema.

O contexto da análise de Vitoria sobre a antropofagia indígena é a discussão espanhola sobre a legitimidade da escravização dos povos que possuíam esse costume $^{7}$. Essa discussão teve seu embasamento na teoria de Aristóteles sobre o escravo natural. Segundo essa teoria, as causas da escravidão natural estariam nos atributos psicológicos do escravo e, em última instância, na constituição do universo, já que:

"Ela depende do axioma, comum à grande parte do pensamento grego, de que existe em todas as formas complexas uma dualidade na qual um elemento naturalmente domina o outro". 8

Dessa forma, a alma humana seria composta por duas partes opostas: o intelecto (lógico), e a paixão (ilógica), as quais uma parte dominaria a outra. Nesse sentido, o escravo natural seria o homem dominado por suas paixões.

Portanto, nessas discussões, as diferenças entre americanos e europeus sobretudo, a antropofagia - foram atribuídas ao domínio das paixões entre os primeiros e usadas para justificar a escravidão indígena ${ }^{9}$. Na reavaliação da legitimidade desta última, Vitoria retoma e compõe uma nova versão da lista dos parâmetros que, segundo Aristóteles, determinavam se um grupo de homens era guiado pela verdadeira razão: a cidade, a linguagem, a indústria, o comércio e a religião.

\footnotetext{
${ }^{7}$ PAGDEN, Anthony. The fall of natural man. Cambridge: Cambridge University Press, 1988. p.60. p.60-5.

${ }^{8}$ Ibidem, p.42.

${ }^{9}$ Ibidem, p.42-8.
} 
Depois da avaliação de cada um desses itens, Vitoria concluiu que os americanos possuíam, embora de forma imperfeita, ou embrionária todos ou quase todos os requisitos necessários para a vida civil, excluindo-se, assim, a possibilidade de que eles seriam escravos naturais ${ }^{10}$. No entanto, restou a questão da antropofagia: Como explicar que homens dotados de razão praticassem uma ação contra a lei natural?

Vitoria reconheceu no canibalismo uma ofensa à natureza racional do homem. No entanto, ele acreditou que esta pratica, junto com outros costumes nativos que também violavam a lei natural, eram produtos da educação bárbara e pobre dos povos americanos, que não permitia que eles deduzissem corretamente a secunda praecepta da lei da natureza, dentro da qual estava a regulamentação da alimentação e da "verdadeira" religião, já que as pessoas instruídas no cristianismo dificilmente deduziam uma falsa praecepta, como era comum acontecer entre os americanos $^{11}$.

Assim, as explicações de Vitoria sobre a antropofagia indígena, ao invés de corroborarem a opinião de alguns cronistas de que esse costume era prova de que os americanos estavam no limbo entre os homens e os animais, legitimaram o projeto missionário, de civilizar e evangelizar os povos americanos, ao afirmarem que estes últimos eram dotados de uma razão que precisava ser educada para que esses povos atingissem o patamar evolutivo em que estava a cristandade européia.

Os padres jesuítas que vieram para o Brasil para evangelizar os "antropófagos", apesar de compartilharem a idéia de Vitoria, segundo a qual os indígenas eram homens dotados de razão ${ }^{12}$, reconheceram na guerra e na antropofagia os principais obstáculos para a realização do projeto missionário, pois eles notaram que os nativos, apesar de, inicialmente, se mostrarem dispostos em aprender a doutrina cristã e em serem batizados, logo voltavam ao seu costume de guerrearem, matarem e comerem seus inimigos ${ }^{13}$. Em vista disso, os missionários

\footnotetext{
${ }^{10}$ PAGDEN, Anthony. Op. Cit., p.69-79.

${ }^{11}$ Ibidem, p. 85-99.

${ }^{12}$ Um documento expressivo da presença dessa idéia entre os jesuítas é o Diálogo sobre a conversão do gentio escrito provavelmente entre os anos de 1556 e 1557 pelo padre Manuel da Nóbrega. Na versão compilada por Serafim Leite a idéia de que o indígena brasileiro, apesar de seus costumes, era um homem dotado de alma aparece entre as páginas 326 e 333. LEITE, Serafim (org) Cartas dos primeiros jesuítas do Brasil.V.2. São Paulo: Comissão do IV Centenário da Cidade de São Paulo, 1954.

${ }^{13} \mathrm{O}$ apontamento da guerra e da antropofagia como os principais obstáculos à conversão nativa aparece em várias cartas escritas pelos missionários jesuítas.
} 
passaram a intervir nos rituais antropofágicos, tentando impedir a execução dos prisioneiros ou batizando esses prisioneiros. Além disso, eles condenavam essas práticas em seus discursos, segundo os quais, esta era uma ação contrária à vontade de Deus.

Por sua vez, no texto dos outros cronistas, que não compartilhavam a preocupação dos missionários jesuítas com a conversão dos nativos, a antropofagia e as guerras serviram para destacar senão uma "bestialidade" nativa - que legitimaria a escravização desses povos - pelo menos, a distância que separava os indígenas brasileiros da civilização. Dessa forma, mesmo o relato de Léry, que buscou relativizar a antropofagia através da sua comparação com as "selvagerias" praticadas pelos europeus ${ }^{14} \mathrm{e}$, que viu as batalhas indígenas como espetáculos prazerosos aos olhos $^{15}$, não deixou de conceber a guerra e a antropofagia como costumes quase bestiais, inspirados pelo Demônio.

Como veremos no segundo capítulo, essa relativização feita por Léry parece ter estrita relação com as perseguições que o autor sofreu por parte dos católicos franceses na colônia brasileira e na França. Nesse sentido, as relativizações que o autor fez daqueles que foram considerados os piores costumes nativos - a guerra e a antropofagia -, parecem constituir mais um ataque aos inimigos europeus do calvinismo, do que uma visão complacente com as diferenças culturais.

Essa posição de Léry em relação à guerra indígena poderá ser vista com mais detalhes na última parte do segundo capítulo onde tentamos analisar a narrativa sobre a origem da guerra registrada em sua obra ${ }^{16}$. Segundo essa versão, as guerras indígenas e a antropofagia, têm início quando, depois da partida do profeta cristão, o Diabo passa a reinar entre os indígenas.

A relação entre o início do domínio do Diabo sobre os indígenas e a origem da guerra e da antropofagia surge também na narrativa registrada por d'Abbeville ${ }^{17}$, o que parece sugerir que essa era uma idéia compartilhada pelos europeus - cujo principal motivo para condenar essa prática parece ter sido sua oposição ao cristianismo - e talvez difundida por estes dentre os indígenas.

Mello e Souza demonstra em seu trabalho que a idéia de que o Diabo reinaria dentre os americanos e que, portanto, estes seriam uma humanidade demoníaca, foi

\footnotetext{
${ }^{14}$ LÉRY, Jean de. Op. Cit., p. 155.

15 Ibidem, p. 144.

${ }^{16}$ Ibidem, p. 168 .

${ }^{17}$ D' ABBEVILLE. Claude. Op. Cit. p.60-1.
} 
uma das formas pelas quais os indígenas foram percebidos pelos europeus. Segundo a autora, na obra dos missionários jesuítas surgem repetidas vezes a afirmação de que os indígenas seriam um "povo do diabo" por conta de seus hábitos alimentares e do seu modo de vestir e de morar. Por sua vez, a via escolhida por Thevet na demonização do indígena foi a relação deste com o sobrenatural, já que os nativos se queixavam constantemente das perseguições que sofriam de Anhã ${ }^{18}$.

Dessa forma, é possível que a relação entre o início do domínio do Diabo e a origem das guerras inter-tribais e da antropofagia entre os indígenas, tenha sido um código construído e compartilhado entre europeus e indígenas no período inicial da colonização, tendo-se em vista tanto a leitura que os europeus fizeram das referidas práticas indígenas (embasada pelo cristianismo que professavam), quanto as ações dos missionários (às quais nos referimos) e dos outros agentes coloniais realizadas para tentar coibir a guerra e a antropofagia (caso do missionários jesuítas), ou para incentivar a guerra e acabar com os rituais antropofágicos. Os discursos e as intervenções européias sobre a guerra e a antropofagia indígena, por sua vez, possivelmente, trouxeram a necessidade dos indígenas re-fundarem essas práticas.

Nesse sentido, tentaremos realizar nossa análise das narrativas sobre a origem da guerra registradas por Léry ${ }^{19}$ e por d'Abbeville ${ }^{20}$ a partir da perspectiva sugerida por Montero para os estudos sobre o encontro intercultural, segundo a qual este poderia ser abordado:

“como processo de produção de códigos de comunicação cuja articulação interna e ordem hierárquica dependerão das exigências de complexidade de cada momento histórico e das prioridades simbólicas dos sistemas. As resultantes contextuais desses processos serão ordens culturais de maior ou menor complexidade em função do tipo de compatibilização de diferenças e conseqüentes graus de generalização que a negociação de significação entre os agentes pôde constituir". ${ }^{21}$

Assim, em relação à guerra e a antropofagia, europeus - principalmente missionários - e indígenas teriam construído um código comum sobre esses costumes

${ }^{18}$ SOUZA, Laura de Mello e. Inferno Atlântico. Demonologia e colonização. São Paulo: Companhia das Letras, 1986. p.67-70.

${ }^{19}$ LÉRY, Jean de. Op. Cit., p.168.

${ }^{20}$ D’ABBEVILLE, Claude. Op. Cit. p.60-1.

${ }^{21}$ MONTERO, Paula. Índios e missionários no Brasil: para uma teoria da mediação cultural. In: MONTERO, Paula (org.) Deus na aldeia: missionários, índios e mediação cultural. São Paulo: Globo, 2006. p. 56-7. 
que, do lado europeu, precisaram ser explicados para justificar como era possível evangelizar povos que praticavam ações tão contrárias à vontade de Deus ou usados para se legitimar a escravização da população nativa; e do lado indígena, precisaram ser explicados para o outro europeu a partir de uma linguagem inteligível para este último e/ ou re-fundados, tendo-se em vista as novidades trazidas pelo encontro com a alteridade européia.

Por fim, embasando uma perspectiva segundo a qual esses registros representariam também uma revisão do patrimônio simbólico indígena, retomamos a perspectiva oferecida pela análise realizada por Pompa do motivo mitológico dos cataclismos na cosmologia tupinambá. Segundo a autora, a presença européia nas terras indígenas trouxe modificações na história e na realidade conhecidas pelos nativos, dando início a:

“um longo e articulado processo que explorou várias possibilidades e estratégias de construção conceptual do outro e de revisão do eu, a partir de situações históricas específicas e tendo em vista o universo simbólico fundador do mundo". ${ }^{22}$

Dentre as estratégias nativas de revisão do eu e construção do outro, apontadas pela autora, destacamos a guerra juntamente com o reajuste do sistema de alianças e conflitos e a via mitológica, em que se codificou, através de novos mitos, "a superioridade dos brancos, os verdadeiros descendentes de Maire-Monan, como diz Thevet, os que tiveram a sorte de escolher, quando da opção mítica, o machado de ferro como diz d'Abbeville" ${ }^{23}$, para embasar nossa hipótese de que os registros de Léry e d'Abbeville sobre a origem da guerra também podem ser lidos como uma refundação mítica da guerra a partir das novidades trazidas pelo contato.

Dessa forma, as narrativas aqui analisadas podem representar o resultado de uma re-função da guerra através dos mecanismos mítico-rituais nativos, a partir da crise gerada pelo contato com a alteridade européia. Tendo contribuído para esses registros tanto a negociação simbólica entre franceses e indígenas (no caso da narrativa registrada por Léry) e entre missionários jesuítas e indígenas (no caso da narrativa registrada por d'Abbeville), quanto as modificações ocorridas na guerra e na antropofagia desde o encontro com a alteridade européia.

\footnotetext{
${ }^{22}$ POMPA, Cristina. Op. Cit., p.188.

${ }^{23}$ Ibidem, p. 189.
} 


\section{CAPÍTULO 1 - A CONSTRUÇÃo do CÓDIGO COMPARTILHADO ENTRE EUROPEUS E INDÍGENAS SOBRE A GUERRA $E$ A ANTROPOFAGIA}

\section{Interpretações sobre a guerra e a antropofagia indígena}

Nos relatos dos séculos XVI e XVII são freqüentes as descrições e as referências ao sistema de vinganças Tupinambá - composto pela guerra e pelo ritual antropofágico - que foi unanimemente condenado e, no caso dos missionários jesuítas, apontado como principal obstáculo à catequese: o sistema de vinganças Tupinambá estava na origem dos maus costumes, pois como os indígenas eram povos "sem fé, nem lei, nem rei", eram seus costumes que deveriam ser modificados para que eles se tornassem "bons" cristãos ${ }^{24}$.

Por sua vez, no início das missões, a dificuldade em identificar algo próximo das idolatrias, o interesse que os Tupinambá demonstravam pela fala dos missionários a respeito de Tupã e os pedidos de batismo feitos aos padres, levaram os missionários a pensarem que a conversão seria facilmente alcançada e que os nativos, depois de convertidos, seriam melhores cristãos do que os colonos portugueses:

"Pois quanto ao gentio da terra vejo tantas mostras que pelo grande empenho que vejo, me põem muitas vezes em confusão para deixar todos os cristãos e meter-me entre eles com todos os Irmãos, e segundo os desejos que esta gentilidade mostra que andemos entre eles, pela vontade que vários deles mostram, tenho por muito certo que começa já o Senhor a olhá-los com olhos de misericórdia. E por não andar já ensinando-los se perderam muitas almas, porque são grandíssimos os desejos que têm de conhecer a Deus e de saber o que irão fazer para salvar-se, porque temem muito a morte e o dia do juízo e o inferno(...),25

\footnotetext{
${ }^{24}$ CASTRO, Eduardo Viveiros de. O mármore e a murta: sobre a inconstância da alma selvagem. In: A inconstância da alma selvagem e outros ensaios de antropologia. São Paulo: Cosac \& Naify, 2002. p.226.

25 trecho por mim traduzido do espanhol da carta do padre Leonardo Nunes aos padres e irmãos de Coimbra, escrita em S. Vicente, em 20 de junho de 1551. In: LEITE, Serafim (S.I.) Cartas dos primeiros jesuítas do Brasil. v.1. São Paulo: Comissão do IV centenário da cidade de São Paulo. São Paulo: 1954.
} 
Contudo, passado os primeiros anos das missões, os padres abandonaram o otimismo inicial ao constatar que os índios, depois de batizados, voltavam aos seus antigos costumes de guerrear e de comer seus inimigos. Anchieta, em carta de 1555, relatava que dois padres da Companhia, Vicente Rodrigues e Francisco Pires haviam desistido da missão em uma aldeia onde os índios, depois de um ano de trabalho dos padres, voltaram aos seus antigos costumes ${ }^{26}$, queixando-se também da participação de seus catecúmenos na guerra e do fato deles quase executarem um prisioneiro na aldeia onde morava. ${ }^{27}$

Viveiros de Castro, ao analisar esses registros, demonstra como neles se contrapõem a inconstância dos Tupinambá no cristianismo missionário à sua constância na guerra e na antropofagia e como, nessa contraposição, estava uma forma peculiar dos indígenas se relacionarem com a alteridade: os Tupinambás ouviam com interesse a palavra dos missionários, pois essa constituía uma característica de sua cultura - a abertura ao outro - contudo, pareciam esquecer com facilidade o que tinham ouvido porque entre eles não existia um sistema coercitivo que os fizesse obedecer a uma "crença":

“A validação da cosmologia nativa pelo recurso à palavra dos pajés e profetas não significava, portanto, uma 'crença' nesta palavra, no sentido político-teológico do termo, porque faltava exatamente o componente de sujeição, de abdicação do juízo e da vontade ${ }^{, 28}$.

Dessa forma, segundo o autor, a essência dessa cultura e, portanto, sua constância estaria em seu sistema de vinganças. Nele, o outro era um termo central para o funcionamento interno do grupo e para a determinação das identidades de seus membros, sobretudo da identidade do guerreiro.

Fausto, em um estudo sobre o simbolismo da guerra entre os grupos indígenas das terras baixas sul americanas - incluindo os Tupinambá - aponta para a centralidade da economia guerreira na formação da personalidade dos indivíduos desses grupos:

\footnotetext{
${ }^{26}$ LEITE, Serafim (S.I.) Cartas dos primeiros jesuítas do Brasil. v.2. São Paulo: Comissão do IV centenário da cidade de São Paulo. São Paulo: 1954. p.195.

${ }^{27}$ Ibidem, p. 206.

${ }^{28}$ VIVEIROS DE CASTRO, Eduardo B. Op. Cit., p. 217.
} 
"Trata-se de economias que produzem pessoas e não objetos, que concebem a relação com o exterior como sendo necessária à reprodução interna e que se articulam com esse exterior primariamente por meio da predação. Ou, dito de outro modo, temos economias que predam e se apropriam de algo fora dos limites do grupo para produzir pessoas dentro dele". ${ }^{29}$

Compartilhando o ponto de vista de Fausto, Viveiros de Castro, em sua análise sobre a "inconstância da alma selvagem", acrescenta que a importância do outro para os Tupinambá não se restringia à incorporação de seus valores através do ritual antropofágico, mas surgia também na vontade dos nativos de se tornarem cristãos, e no apreço que eles tinham pelas mercadorias européias:

"As eventuais vantagens práticas que buscavam ao declarar seu desejo de conversão estavam imersas em um calcul sauvage (Sahlins, 1985) onde ser como os brancos - e o ser dos brancos - era um valor disputado no mercado simbólico indígena. Os implementos europeus, além de sua óbvia utilidade, eram também signos dos poderes da exterioridade, que cumpria capturar, incorporar e fazer circular, exatamente como a escrita, as roupas, os salamaleques rituais dos missionários, a cosmologia bizarra que propalavam", ${ }^{30}$

Ao relacionar o papel do outro, inimigo de guerra, ao papel do outro, europeu, para afirmar a abertura das sociedades indígenas para os estrangeiros, Viveiros de Castro, nos propõe em seu ensaio uma interessante pista a ser investigada: a abertura dos Tupinambá aos europeus seria similar à sua abertura aos inimigos, ou, em outras palavras, o papel do inimigo na construção da identidade Tupinambá, seria análogo ao papel do europeu na construção da referida identidade?

Tentar investigar essa questão nos é necessário, pois nesse trabalho nos propomos a analisar as narrativas indígenas sobre a origem da guerra a partir da perspectiva segundo a qual essas narrativas seriam códigos construídos e compartilhados pelos Tupinambá e pelos europeus. Sendo a guerra o tema dessas narrativas e também uma forma de relação entre os Tupinambá e a alteridade, pensamos ser necessário analisar a inter-relação entre esses temas.

${ }^{29}$ FAUSTO, Carlos. Da inimizade. Forma e simbolismo da guerra indígena. In: NOVAES, Adauto (org.). A outra margem do ocidente. Brasília-DF: MINC-FUNARTE; São Paulo: Companhia das Letras, 1999, p.266.

${ }^{30}$ CASTRO, Eduardo Viveiros de. Op. Cit. p.223-4. 
Para tentar responder a essa questão, pensamos ser necessário verificar o papel da vingança (segundo as fontes, apontada pelos indígenas como o motivo de suas guerras) e da antropofagia (indicada pelas fontes e por alguns estudos como "o instrumento da "perpetuação dos ódios"” e, portanto, responsável pela continuidade das guerras) entre os Tupinambá a partir de outras análises realizadas sobre esse tema, além de avaliar as concepções indígenas sobre o europeu, assim como a relação desenvolvida entre este e os Tupinambá.

Florestan Fernandes, em seu trabalho sobre a função social da guerra, é quem demonstra, pela primeira vez, a centralidade desta para os Tupinambá: era em função do sentido mágico-religioso da guerra que o grupo social se organizava e era ao redor dela que giravam as principais atividades da aldeia:

“Ora, as descrições das 'situações de vida', enfrentadas pelos Tupinambá nessa época, mostram que os fatores externos dominantes (que não só davam sentido às ações sociais e às aspirações mais profundas dos indivíduos, mas ainda conformavam a própria manifestação e a ordenação dos demais fatores), eram de natureza religiosa. Em torno das obrigações dos vivos para com os mortos, da vingança dos antepassados e da satisfação dos desejos antropofágicos dos espíritos, é que se polarizavam as vivências masculinas e os núcleos de condensação e de intensificação da vida social, especialmente dos homens. "31

Assim, segundo Florestan Fernandes, a guerra era uma instituição subordinada ao sistema religioso tribal, que tinha como móvel principal a vingança contra as ofensas praticadas contra os parentes mortos e os ancestrais míticos. Por constituir a religião do grupo social, a vingança era realizada, direta ou indiretamente por todos os membros do grupo. No entanto, ela era polarizada em torno dos homens, pois eram eles que participavam das atividades militares da guerra. ${ }^{32}$

Por isso, a vida social e religiosa dos homens era a mais determinada, dentro do grupo, pelas atividades guerreiras e, conseqüentemente, pela relação com os inimigos. Os adestramentos específicos do guerreiro ocorriam quando o homem tinha entre 15 e 25 anos. Atingida a idade adulta, os homens poderiam combater nas guerras, sendo considerados guerreiros, somente quando "conseguissem aprisionar

\footnotetext{
${ }^{31}$ FERNANDES, Florestan. A função social da guerra na sociedade Tupinambá. São Paulo: Livraria Pioneira; Edusp, 1970. p.153.

${ }^{32}$ Ibidem, p. 148 .
} 
um inimigo e sacrificá-lo ritualmente" ${ }^{33}$. A partir desse momento, o indivíduo atingia a categoria de Ava que era a mais importante da vida de um homem ${ }^{34}$, pois:

“correspondia do princípio ao fim, aos 'anos de decisão' em que se resolvia, no sentido mais amplo possivel, o destino dos homens - seja quanto ao curso imediato e futuro da existência terrena, seja quanto às relações com os espíritos dos antepassados e à perspectiva de uma existência post-mortem conforme aos ideais de vida futura no além". ${ }^{35}$

Agnolin, a partir de uma leitura histórico-religiosa da análise proposta por Fernandes, reitera a importância dessa fase para o homem tupinambá: era a partir da realização dos ritos de sacrifício do inimigo e de renomação do matador, que nascia o homem (cultural) ${ }^{36}$. Apoiando essa idéia, o autor retoma a análise de Brelich, segundo a qual:

"vale a pena lembrar, de acordo com Brelich, que se o segundo nascimento (as transformações das iniciações rituais) cria o homem cultural, este é o único, verdadeiro homem que uma cultura pode reconhecer. Esse fato implica a 'morte' do iniciando qual ele era antes da sua iniciação. E se, em conseqüência disso, 'morte $\mathrm{e}$ nascimento 'rituais' não significam uma substituição alegórica da morte e do nascimento reais [...] o nascimento e a morte fisiológicos não têm, para as sociedades primitivas, uma realidade completa até que não sejam ritualizadas, porque os fatos puramente naturais não são unanimemente significativos' ", 37

A análise que Fernandes realiza sobre os ritos que compõem aquilo que ele denomina como "ciclo de guerra" também enfatiza que o papel do inimigo na vida do executor, não se restringe ao momento em que o homem atinge o status social de avá, mas se estende por todo o período em que o homem participa das atividades

\footnotetext{
${ }^{33}$ FERNANDES, Florestan. Op. Cit., p.143.

${ }^{34}$ FERNANDES, Florestan. A organização social dos Tupinambá. São Paulo: Difusão européia do livro, 1963. p. 275.

${ }^{35}$ FERNANDES, Florestan. A função social da guerra na sociedade Tupinambá. São Paulo: Livraria Pioneira; Edusp, 1970. p.152.

${ }^{36}$ AGNOLIN, Adone. O apetite da antropologia, o sabor antropofágico do saber antropológico: alteridade e identidade no caso Tupinambá. São Paulo: Associação Editorial Humanitas, 2005. p.319.

${ }^{37}$ Ibidem, p.335.
} 
guerreiras, criando uma relação de dependência do inimigo, a partir do momento da sua captura:

"sem ela [a vítima do sacrifício], seria impossivel estabelecer a espécie de comunicação com o sagrado que garantia aos Tupinambá a aquisição de 'nomes' $e$ a correspondente rotinização de carisma. Isso quer dizer que todo o processo social em que repousavam a agregação ao círculo social dos adultos e a objetivação diferenciadora de prestígio social estava, em certo sentido, subordinado às relações do senhor e do escravo". ${ }^{38}$

Por outro lado, o inimigo capturado também dependia do seu senhor na medida em que, a partir da sua captura, ele tinha obrigatoriamente que morrer nas mãos do inimigo. Seu retorno à sua antiga comunidade implicaria na sua morte nas mãos dos seus, pois esse tipo de atitude era interpretado como uma desconfiança da pessoa capturada em relação à capacidade do grupo em vingar a sua morte. ${ }^{39}$

O guerreiro capturado perdia temporariamente, o vínculo com a sua comunidade: ritos de integração eram realizados para a anulação temporária da sua diferença em relação ao grupo dos seus captores. Segundo Fernandes,

"a ligação das pessoas dos cativos com as entidades às quais os massacres seriam votados, se processava como requisito da atribuição de status [aos cativos] na comunidade dos captores" ${ }^{, 40}$.

Dessa forma, depois de ligado à entidade à qual seria sacrificado, o "escravo" era incorporado à unidade familiar do seu "senhor", por intermédio da:

“concessão de companheiras aos escravos e a agregação das escravas aos lares políginos dos captores contribuíam para resolver praticamente os problemas de definição de status no grupo (...) e de tratamento recíproco, criados por essa forma de ajustamento social entre captores e cativos. Os trabalhos que estes realizavam, especialmente os jovens e as mulheres, e a forma de apropriação dos produtos de

\footnotetext{
${ }^{38}$ FERNANDES, Florestan. A função social da guerra na sociedade Tupinambá. São Paulo: Livraria Pioneira; Edusp, 1970. p.254.

${ }^{39}$ Ibidem, p. 254-5.

${ }^{40}$ FERNANDES, Florestan. Op. Cit., p. 256.
} 
suas atividades, subentendiam a transferência de obrigações recíprocas entre 'pai' $e$ 'filho' ou entre 'marido' e 'esposa' para a pessoa dos escravos". ${ }^{41}$

O vínculo perdido com o seu grupo só era recuperado a partir da proximidade do momento da sua execução ritual, quando realizavam-se ritos destinados a desligálo do grupo de seu captor. Essa separação ocorria e era reiterada através dos ritos de destruição do inimigo, que segundo Florestan Fernandes eram seis:

“a) ritos de separação da vítima; b) ritos de inculpação da vítima; c) ritos de preparação da vítima; d) ritos de captura simbólica da vítima; e) ritos de vingança simbólica da vítima; $f$ ) ritos de execução", ${ }^{42}$

Portanto, se logo após a captura, o inimigo era incorporado ao grupo de seus captores, quando se aproximava a data da sua execução, sua diferença em relação a esse grupo precisava ser re-afirmada, por intermédio de uma série de ritos que lhe davam a oportunidade de re-memorar as ofensas que seu grupo praticou contra os inimigos que agora dele se vingariam, assim como a oportunidade dele mesmo vingar sua morte - se a sua destruição não fosse completa.

Dessa forma, a execução dos prisioneiros trazia riscos tanto para a comunidade do sacrificante quanto para o próprio sacrificante: a alma do inimigo morto poderia realizar represálias ao seu executor e a todos aqueles que participaram dos ritos destinados ao seu sacrifício ${ }^{43}$. Para afastar o perigo representado pelo inimigo sacrificado, o grupo que participara de sua execução, assim como o seu executor, deveriam realizar ritos que tinham como objetivos:

“1) consumar a 'destruição' da vítima; 2) evitar que o seu 'espírito' se tornasse nefasto para o sacrificante e para a comunidade. O primeiro objetivo era conseguido através da antropofagia ritual; o segundo, em parte por meio dela, mas especialmente por intermédio dos ritos de purificação do sacrificante ou ritos de renomação". 44

\footnotetext{
${ }^{41}$ FERNANDES, Florestan. Op. Cit., p.262.

${ }^{42}$ Ibidem, p. 270.

${ }^{43}$ Ibidem, p. 290.

${ }^{44}$ Ibidem, p. 289.
} 
Prosseguindo com sua análise Fernandes conclui que era a diferença representada pelo inimigo que permitia a realização do seu sacrifício aos ancestrais míticos e aos parentes mortos, já que esses sacrifícios possuíam uma dialética interna segundo a qual, eles constituíam uma cadeia fechada onde se desenvolvia a relação entre vivos e mortos, que se movimentava através "do massacres de vítimas sucessivas aos mesmos espíritos" ${ }^{45}$; e a necessidade que o grupo tinha das vítimas, "provinha, antes mesmo que da existência de uma 'ofensa anterior' imediata da própria realidade do sacrifício humano na sociedade tupinambá". ${ }^{46}$

Portanto, para Fernandes aquilo que ele denominou como a "idéia diretriz" da noção de vingança dos Tupinambá era:

“a intenção de socorrer o 'espírito' de um antepassado, morto em condições que punham em risco a integridade de sua 'pessoa', ou de satisfazer a necessidade de relação sacrificial do espírito de um antepassado ou ancestral mítico", ${ }^{47}$

No entanto, a idéia da guerra e da vingança como instrumentos religiosos de "socorro" aos antepassados, não exclui, na análise de Fernandes, a função dos inimigos na determinação da identidade do grupo, sobretudo, dos homens, pois era na relação entre estes e os inimigos, que eles nasciam culturalmente, construíam seu prestígio na sociedade dos vivos e dos mortos, e corriam riscos de perda da própria identidade depois da execução desses inimigos. Como constatou Agnolin a partir da análise de Florestan Fernandes:

“A identidade cultural Tupi é sempre, continuamente, posta em jogo pela alteridade - ritualmente determinada e controlada - a qual, por conseqüência, constitui necessariamente o próprio núcleo da identidade. Assumir essa identidade na alteridade' delineia, portanto, a característica que responde, de forma plena, ao modelo cultural indígena." 48

\footnotetext{
${ }^{45}$ FERNANDES, Florestan. Op. Cit., €p. 319.

${ }^{46}$ Ibidem, p. 320.

${ }^{47}$ Ibidem.

${ }^{48}$ AGNOLIN, Adone. Op. Cit., p.317.
} 
Em suma, todos os autores aqui analisados parecem concordar com a participação do inimigo na construção da identidade tupinambá. No entanto, como veremos a seguir, há discordâncias quanto ao peso dessa participação.

Para Fausto, o inimigo desempenhava um papel central para o grupo, pois era a relação com esse inimigo por intermédio da guerra que possibilitava a "fabricação" de pessoas dentro do grupo: segundo o autor, as sociedades indígenas das terras baixas sul-americanas se relacionariam com o exterior através de duas modalidades a troca e a predação. Em algumas sociedades - esse seria o caso da sociedade Tupinambá - prevaleceria a relação com o exterior por intermédio da predação. Como essa predação destrói sujeitos no exterior para produzir pessoas no interior do grupo, o autor denominou essa forma de relação como um "consumo produtivo"49. Nessas sociedades, o xamã e o matador teriam um papel central, pois eles seriam os responsáveis pelo controle do outro.

Como vimos no início do capítulo, Viveiros de Castro a partir de um ponto de vista parecido, menciona a centralidade da guerra para os indígenas, apontando a abertura ao outro como um termo central da sociedade tupinambá, todavia, negando $\mathrm{o}$ aspecto religioso da guerra e a capacidade coercitiva desse sistema ${ }^{50}$.

Já para Florestan Fernandes, como verificamos há pouco, a função do inimigo é secundária, já que a realização da guerra tinha como objetivo principal satisfazer as demandas dos parentes mortos: ou seja, era para atender necessidades internas que se capturava e destruía pessoas "de fora" do grupo. Assim, a participação do inimigo na construção da identidade masculina, era uma conseqüência de um sistema religioso cujo núcleo era o sacrifício da alteridade aos parentes mortos e aos ancestrais míticos $^{51}$.

Agnolin, aceita a proposta de Fernandes, ainda que em uma perspectiva diferenciada, já que a mesma dá ênfase ao aspecto religioso do sistema de vinganças indígena. Analisando o ritual antropofágico, o autor reitera a importância da alteridade no complexo mítico-ritual nativo de construção da identidade do grupo ${ }^{52}$. Isso porque, Agnolin embasa sua análise na perspectiva histórico-religiosa oferecida por De Martino, segundo a qual seriam os mecanismos mítico-rituais os dispositivos que apontariam os riscos, forneceriam o horizonte simbólico para as alienações

\footnotetext{
${ }^{49}$ FAUSTO, Carlos. Op. Cit., p.265-7.

${ }^{50}$ CASTRO, Eduardo Viveiros de. Op. Cit.

${ }^{51}$ FERNANDES, Florestan. Op. Cit.

${ }^{52}$ AGNOLIN, Adone. Op. Cit. p.317.
} 
recorrentes e transformariam o retorno do passado em repetições ativas e resolutivas, abertas às regras humanas e aos valores culturais ${ }^{53}$.

Para a análise da participação dos inimigos de guerra na construção da identidade Tupinambá, nos apoiaremos na perspectiva oferecida por Agnolin, reiterando, dessa forma, o aspecto mítico-ritual das guerras inter-tribais e, conseqüentemente, da relação entre as tribos inimigas.

$$
\text { - * }
$$

Nesse ponto podemos retomar a questão que propomos no início do capítulo. Como vimos, Viveiros de Castro, em seu ensaio, sugere que a abertura ao outro seria uma característica da sociedade Tupinambá, que poderia ser apreendida tanto na relação entre os Tupinambá e seus inimigos, quanto na relação entre os primeiros e os europeus. A partir dessa proposta questionamos: o papel do inimigo na construção da identidade Tupinambá, seria análogo ao papel do europeu na construção da referida identidade?

A breve análise que realizamos há pouco, nos apresentou o complexo míticoritual, como o mecanismo por meio do qual, os indígenas se relacionavam com o outro, inimigo de guerra. Essa perspectiva de análise parece localizar nesses dispositivos o lugar da abertura nativa à alteridade. Por sua vez, como apontamos na introdução, alguns estudos constataram que a alteridade européia foi inicialmente interpretada pelas culturas não ocidentais por intermédio do seu sistema cosmológico. Portanto, tudo indica que a abertura nativa à alteridade se dava pelos mecanismos mítico-rituais que, segundo a proposta de análise desse trabalho são os responsáveis tanto pela significação da realidade, quanto pela assimilação da história (ou da diferença).

Assim, tanto os inimigos de guerra quanto os estrangeiros recebiam sua significação por intermédio dos mecanismos mítico-rituais. Porém, a abertura aos inimigos de guerra e aos europeus parece ser de tipos diferenciados: a abertura dos Tupinambá aos inimigos de guerra se explica pelo fato destes últimos compartilharem aquilo que parece ser primordial para sua cultura, a vingança e a guerra e, por isso, estes participam da construção da identidade do grupo; a abertura

\footnotetext{
${ }^{53}$ DE MARTINO, Ernesto. Fuore, símbolo, valore. Milão: Fetrinelli, 1980, p.112. apud.: AGNOLIN, Adone. Op. Cit., p. 331. Essa idéia também encontra-se presente em outra obra de De Martino, a saber: DE MARTINO, Ernesto. Il mondo magico: prolegomeni a una storia del magismo. Torino: Eniaudi, 1948. apud: POMPA, Cristina. Memórias do fim do mundo: Para uma leitura do movimento sócioreigioso de Pau de Colher. Dissertação de Mestrado. Campinas, Unicamp, 1995.
} 
Tupinambá à alteridade européia, tal qual ela é constatada por Viveiros de Castro, ou seja, como uma "boa disposição" em conhecer as "mitologias" desse outro, possivelmente se explica, primeiramente, pelo fato desse outro ter sido concebido como um herói mítico que retornara ao mundo dos homens e, com o passar do tempo, pelo fato dos missionários terem reforçado esse mal-entendido, na sua disputa com os pajés indígenas, pela "alma” dos nativos.

Além disso, como o próprio Viveiros de Castro verificou, essa abertura tem outros interesses que não se restringem à "cosmologia" apresentada por esse outro: a cultura material da alteridade européia parece auxiliar a sua associação com os ancestrais míticos e, dessa forma, se torna um objeto de interesse dos indígenas equivalente à "cosmologia" difundida pelos padres. Nesse sentido, cultura material e "cosmologia" se tornaram, como Viveiros de Castro afirmou, "signos dos poderes da exterioridade, que cumpria capturar, incorporar e fazer circular" ${ }^{\prime \prime}$.

Acreditamos, portanto, que esse tenha sido o sentido da participação européia (sobretudo missionária) na construção da identidade indígena: recebendo, inicialmente, sua significação dos mecanismos mítico-rituais, os europeus, sobretudo os missionários, são re-significados ao longo da convivência com os nativos, sendo que, o novo sentido que assumem é o produto de uma construção conjunta, em que os códigos das culturas em contato têm seu sentido negociado. É nessa negociação de sentido que vemos a abertura nativa a participação desse outro na construção da sua identidade.

A "cosmologia" difundida pelos missionários parece ter trazido, além de novos conteúdos, uma nova concepção de tempo para os indígenas. No entanto, como constatou Pompa em sua análise sobre o mito da Terra sem Mal, nas fontes analisadas e na maior parte dos estudos sobre a religiosidade Tupinambá, fala-se de um milenarismo tupi, pré-existente ao contato, e que permaneceu intacto do século XVI ao XX, podendo ser encontrado tanto entre os Tupinambá dos primeiros séculos de colonização, quanto entre os Guarani contemporâneos ${ }^{55}$.

\footnotetext{
${ }^{54}$ CASTRO, Eduardo B. Viveiros de. Op. Cit., p.224

${ }^{55}$ POMPA, Cristina. Op. Cit., p.99.
} 
Como a autora demonstra na primeira parte de sua obra, esse milenarismo não pode ser lido como um elemento constituinte da cultura indígena antes do "encontro" com a alteridade européia, já que ele ocupa uma posição privilegiada na “interpretação indígena da realidade trazida pelo contato e na maneira indígena de transformar histórica e politicamente esta realidade". ${ }^{56}$ Nesse sentido, o ritual adquire o importante papel de estabelecer "uma 'ponte' entre o passado mítico e o tempo

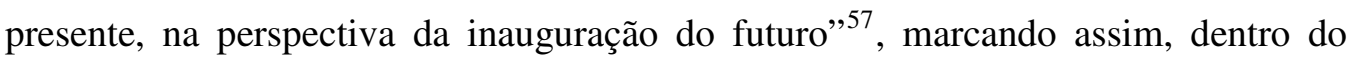
milenarismo, a coexistência de temporalidades distintas ${ }^{58}$.

Dessa forma, como veremos a seguir, esses movimentos, assim como a cosmologia e os rituais narrados pelas cronistas podem ser lidos como uma construção realizada por índios e jesuítas durante a missão. Todavia, alguns estudos sobre os Tupinambá, abordaram esses temas sem a necessária crítica às fontes que forneceram essas informações. No presente estudo tal idéia é problemática, pois não considera a importância da ação missionária na construção de uma nova concepção de tempo entre os Tupinambá e em uma possível re-fundação do pensamento mitológico indígena.

A idéia de que o futuro fazia parte da concepção de tempo dos grupos tupi antes do contato parece influenciar o estudo que Viveiros de Castro e Carneiro da Cunha $^{59}$ fizeram sobre o sentido da vingança para os Tupinambá. Como veremos a seguir, as conclusões desses autores apontam a vingança como a produtora da memória e do futuro entre os indígenas. No entanto, antes de abordarmos a conclusão desse estudo, faz-se necessário confrontar o sentido da vingança e da antropofagia dos referidos autores, com a análise que Fernandes fez sobre esse tema, já que seu estudo analisou diretamente e de forma sistemática a guerra indígena como um todo.

Viveiros de Castro e Carneiro da Cunha viram na vingança indígena, realizada através do ritual antropofágico, o lugar de produção do tempo e da memória do grupo. Primeiramente, eles constataram dois tipos de vingança, ou de retaliação à agressão entre os Tupinambá: um modo responde imediatamente à agressão recebida e assim, cancela a possibilidade de uma agressão futura; o outro modo, perpetua a vingança a partir da agressão. Esse segundo tipo de vingança,

\footnotetext{
${ }^{56}$ POMPA, Cristina. Op. Cit. p. 166.

${ }^{57}$ Ibidem, p. 167.

${ }^{58}$ Ibidem, p. 167.

${ }^{59}$ CUNHA, Manuela L. Carneiro da; CASTRO, Eduardo B. Viveiros de; Vingança e temporalidade: os Tupinambá. Journal de la Societe des Americanistes. Paris, v.71, p.191-208, 1985.
} 
segundo os autores "caracteriza os inimigos como permanentes e a vingança como interminável. Esta vingança, ao contrário da outra, ficará para sempre inconclusa" ${ }^{60}$

Com esse segundo tipo de vingança eles identificaram a antropofagia como o ritual essencial para realizá-la, pois:

"sem ela, não se produz, no que chamamos acima o átomo da vingança, a qualificação de 'inimigo' em escala suficiente para que a vingança possa continuar. O canibalismo é a condição de perpetuação do sistema: não diziam outra coisa os Tupinambá quando faziam dele o instrumento da 'perpetuação dos ódios', requentados, à falta de novas vítimas, graças a banquetes com carnes de inimigos de conserva". ${ }^{61}$

Por sua vez, Florestan Fernandes, no seu questionamento sobre a função dos rituais que compunham o sistema de vinganças nativo, identificou três "conexões sócio-culturais das ações canibalísticas": a vingança contra os inimigos; a preservação da unidade grupal; e a captação das energias dos inimigos por intermédio da ingestão da sua carne. Entretanto, dos três motivos apontados, apenas o último foi por ele identificado como "uma conexão imediata das ações canibalísticas" ${ }^{62}$, já que:

“Os dois primeiros motivos, a noção de vingança e a de comunhão do 'nosso grupo', não se ligavam exclusivamente à antropofagia. Ambos se vinculavam ao conjunto de ações integradas ao sacrifício humano, visto como um todo. No entanto, cada uma das três determinações da noção de vingança e a consistência dos laços de solidariedade grupal se prendiam, de maneira peculiar, como se mostrará adiante, às ações canibalísticas". ${ }^{63}$

Portanto, se Carneiro da Cunha e Viveiros de Castro vinculam apenas antropofagia e vingança, Fernandes constata outras três relações com a antropofagia, sendo "antropofagia" e "vingança" apenas uma delas. Especificamente em relação a essa última ligação, o autor aponta que apesar desses dois termos se relacionarem de forma peculiar, a vingança não se ligava exclusivamente à antropofagia.

\footnotetext{
${ }^{60}$ Ibidem, p. 197.

${ }^{61}$ CUNHA, Manuela L. Carneiro da; CASTRO, Eduardo B. Viveiros de. Op. Cit., p.198.

${ }^{62}$ FERNANDES, Florestan. Op. Cit., p.297-300.

${ }^{63}$ Ibidem, p.300.
} 
Como vimos há pouco, Fernandes indica a relação com os antepassados e as entidades míticas como preponderantes nas ações destinadas à "vingança" realizadas pelo grupo. Nesse sentido, as excursões de guerra, a captura dos inimigos, e os ritos que ocorriam a partir da inserção desse inimigo no grupo até algum tempo depois de sua execução, tinham como objetivo principal satisfazer as necessidades dos mortos. Dessa forma, a "vingança" se exprimiria na sociedade:

"na relação existente entre as ações que deviam ser praticadas contra os inimigos $e$ as obrigações definidas pela necessidade do sacrifício humano. A guerra nascia de motivos rituais, de ordem mágico-religiosa, e se prendia à necessidade de se estabelecer uma relação sacrificial como o efeito à sua causa; ela era, sob esse ponto de vista, uma conseqüência do fato da vítima não ser escolhida dentro do 'nosso grupo', mas fora dele". ${ }^{64}$

Nessa chave de leitura, a vingança é associada a todos os ritos que compõem o "ciclo da guerra", sendo a antropofagia um rito importante, cujas funções se relacionavam com o sentido mágico-religioso da guerra que, como vimos, visava principalmente atender às demandas dos mortos e dos ancestrais míticos. Dessa forma, o inimigo era um instrumento da relação entre os vivos e os mortos do grupo, e a ingestão de sua carne:

“constituía uma forma de comunhão coletiva no processo de recuperação mística desencadeado pela relação sacrificial, a qual produzia resultados mágicos que se refletiam na condição do grupo hostil 'vencido' e asseguravam as vantagens oriundas da supremacia guerreira ou da 'vitória militar'. Por isto, esta conexão específica continha os elementos ideológicos ou as razões cognitivas que, no horizonte mental dos Tupinambá, serviam para 'explicar' racionalmente os móveis da guerra e do massacre dos inimigos capturados em face da necessidade de vingar os parentes mortos recentemente ou os antepassados memoráveis e os ancestrais míticos". ${ }^{65}$

Retomando: o vínculo entre antropofagia e vingança, apontado por Carneiro da Cunha e Viveiros de Castro como elemento central da perpetuação da guerra entre

${ }_{65}^{64}$ FERNANDES, Florestan. Op. Cit. p.321.

${ }^{65}$ Ibidem, p. 328. 
os indígenas - pois, segundo esses autores, era o ato de comer a carne de um "afim" que constituía a razão para que o outro fosse classificado como inimigo ${ }^{66}$ - para Fernandes, constituía a justificativa ideológica e cognitiva que os indígenas davam para a guerra que, todavia, não era a relação central na determinação do "ciclo da guerra".

Apontada como o elemento que propiciava a perpetuação da guerra, por Carneiro da Cunha e Viveiros de Castro, a vingança por intermédio da antropofagia constituía, segundo os autores, o tema da memória e, assim, o mecanismo pelo qual a temporalidade era produzida dentre os Tupinambá:

“a vingança tupinambá fala apenas, mas de forma essencial, do passado e do futuro. É ela, e somente ela, que põe em conexão os que já viveram (e morreram) e os que viverão, que explicita uma continuidade que não é dada em nenhuma outra instância". 67

Mais adiante os autores ressaltam que a temporalidade produzida por intermédio da memória da vingança não constituía, como afirmou Florestan Fernandes, "um meio para a restauração da integridade de uma sociedade ferida pela morte de seus membros" ${ }^{\prime 68}$, mas uma forma de se produzir o futuro a partir de uma realidade fundada sobre a vingança:

"Não se trata de haver vingança porque as pessoas morrem e precisam ser resgatadas do fluxo destruidor do tempo; trata-se de morrer para haver vingança, $e$ assim haver futuro. Forma de por a morte a serviço da vida, não combate contra a morte. A vingança é uma mnemotécnica, mas é mobilizada para a produção de um futuro". ${ }^{69}$

Ao que parece, a concepção de tempo e de memória, presente no estudo de Carneiro da Cunha e Viveiros de Castro, apesar de coincidir com o estudo de Fernandes ao apontar a centralidade da vingança para os Tupinambá, inverte a perspectiva oferecida pelo autor, segundo a qual a vingança acontecia para atender demandas criadas por aqueles que não compõem mais a sociedade dos vivos.

${ }^{66}$ CUNHA, Manuela L. Carneiro da; CASTRO, Eduardo B. Viveiros de. Op. Cit. p.198.

67 Ibidem.

${ }^{68}$ Ibidem, p.200.

${ }^{69}$ Ibidem, p. 201. 
Além disso, a concepção do tempo indígena dos referidos autores, como apontou Agnolin ${ }^{70}$ na análise de um outro estudo de Viveiros de Castro ${ }^{71}$, "parece aludir a uma (...) paradoxal escatologia tupi", ${ }^{72}$ sem, no entanto, considerar que a idéia de futuro, ou "a consciência do tempo e da história", foi inserida na cultura indígena a partir do seu contato com o cristianismo. É a religião cristã que inaugura:

"um processo escatológico que se atua no tempo, [o qual] não somente abre espaço de fato à história humana, mas levanta o véu sobre a historicidade da condição humana e funda de jure na perspectiva da fé, o sentido da obra, a consciência de tensão entre 'situação' e 'valor'. [E] se a civilização ocidental conquistou por si, no curso de sua história, uma hegemonia fundada sobre a potência do operar mundano [...] a relação subsiste e confere à história do Ocidente a sua fisionomia que não pode ser confundida". ${ }^{73}$

Dentro de uma perspectiva histórico-religiosa (que é a de nosso estudo), a história e a inserção da perspectiva histórica não podem ser desprezadas. Assim considerando-se o 'ciclo da guerra' - sobretudo o ritual antropofágico e as falas nativas sobre a guerra e a vingança, registradas pelos cronistas - como integrante do sistema mágico-religioso nativo que fundava a cultura Tupinambá, como sugeriu Fernandes; e considerando-se que os registros sobre essa cultura só foram realizados a partir do contato (essa idéia é imprescindível para o estudo que vamos realizar), analisaremos as questões do tempo e da memória da guerra entre os indígenas a partir da idéia de que essas categorias, tal qual elas surgem nas fontes primárias, são o produto da negociação simbólica entre indígenas e missionários, nos primeiros séculos de colonização, e a partir de uma perspectiva que permita apreender a relação entre mito, rito e história.

Como apontamos anteriormente, essa perspectiva é dada pela proposta de De Martino que analisa a forma como a história opera nas sociedades extra-ocidentais. Na obra Il mondo magico: prolegomeni a una storia del magismo ${ }^{74}$ (1948), o autor

\footnotetext{
${ }^{70}$ AGNOLIN, Adone. Op. Cit.

${ }^{71}$ VIVEIROS DE CASTRO, Eduardo B. Araweté: os deuses canibais. Rio de Janeiro: Jorge Zahar, 1986.

72 AGNOLIN, Adone. Op. Cit. p.330.

${ }^{73}$ DE MARTINO, Ernesto. Furore, simbolo, valore. Milão: Fertinelli, 1980. In: AGNOLIN, Adone. Op. Cit. p.330.

${ }^{74}$ Conforme poderá ser visto, por meio das indicações de autoria no corpo do texto, ainda não tive a oportunidade de ler o trabalhos de De Martino acima mencionado. Contudo, uma pesquisa sobre os
} 
demonstra que nas sociedades tradicionais, a presença atuante do homem no mundo constitui uma realidade a ser construída. Dessa forma, a simbologia mítico-ritual possui o importante papel de fundar a presença do homem no mundo assim como de protegê-lo contra a ameaça de "não ser mais no mundo". Essa ameaça se apresentaria à sociedade através dos acontecimentos não previstos e, por isso, geradores de uma crise a ser resolvida socialmente através do ritual que re-atualizaria os tempos míticos da fundação do mundo.

Durante a resolução da crise, o devir seria de-historificado, e se instauraria assim um regime protegido ${ }^{75}$. Contudo, em De Martino, isso não representaria a negação da história (com o sentido de curso dos acontecimentos), e sim a forma segundo a qual o homem recupera o tempo e sua realidade profana:

"O tempo cíclico dos mitos de origem e de fundação (...) é um tempo protetor da historicidade do devir, enquanto resolve os momentos críticos da existência em soluções exemplares, já acontecidas in illo tempore, por obra dos numes (...) Desta maneira, a decisão humana daqueles momentos desenvolve-se sob a proteção da decisão já tomada no plano mítico. O que significa que, através da pia fraus do estar na história como se aí não estivesse, o estar efetivo é reaberto na operacionalidade profana, garantido, quanto a resultados e perspectivas pelo já decidido in illo tempore" ${ }^{, 76}$.

Assim, segundo a perspectiva acima apresentada de forma sucinta, a crise instaurada pela presença de elementos não previstos miticamente - representados pela presença européia e sua forma peculiar de relação com os Tupinambá - seria resolvida através do acionamento dos mecanismos mítico-rituais que re-fundariam as bases dos elementos culturais questionados a partir do confronto com a alteridade.

sentidos assumidos pelo termo mito, desde o início dos estudos do Ocidente sobre esse tema, demonstrou a insuficiência da maior parte dessas concepções, para o meu estudo. Reconheço a proximidade dessa concepção de mito, com aquela utilizada por Sahlins (1990), com a qual também trabalho nesse estudo. Todavia, achei necessário utilizar a perspectiva teórica oferecida por De Martino, pelo fato deste apresentar elementos necessários à discussão que eu aqui proponho. Tive contato com vários trabalhos que me propiciaram o conhecimento da obra desse autor: Mazzoleni (1992), Pompa (1995), Agnolin, (1998), Pompa (2003), Massenzio (2005). Contudo, os comentários à obra supra-citada foram elaborados com base no trabalho de Cristina Pompa: Memórias do fim do mundo: Para uma leitura do movimento sócio-reigioso de Pau de Colher. Dissertação de Mestrado. Campinas, Unicamp, 1995.

${ }^{75}$ POMPA, Cristina. Memórias do fim do mundo: Para uma leitura do movimento sócio-reigioso de Pau de Colher. Dissertação de Mestrado. Campinas, Unicamp, 1995. p.54-5.

${ }^{76}$ Ibidem, p.55. 
O viés analítico proposto por De Martino é utilizado por Pompa em sua análise da cosmologia indígena que foi apontada por Métraux e Hélène Clastres como fundadora da idéia de fim do mundo na qual se embasariam as migrações nativas em busca da Terra sem Mal. Elegendo como fonte os registros de Thevet do motivo mitológico dos cataclismos, a autora demonstra que nesses registros a catástrofe possui uma ação fundadora: "ela modifica a realidade caótica primordial, introduzindo os elementos que caracterizariam a sistematização ordenada do cosmos"

Dessa forma, o primeiro cataclismo registrado por Thevet - aquele em que a Terra foi destruída pelo fogo - fundou a ordem social e geográfica; por sua vez, o segundo cataclismo - a inundação causada pela briga dos irmãos Tamendore e Ariconte - estabeleceu a mediação adequada entre céu e terra. Mais adiante, a autora observa que a cosmologia tupinambá concebe a possibilidade do advento de um novo cataclismo, já que a análise estrutural dos mitos sobre a destruição do mundo demonstra que esse aniquilamento pode ocorrer todas as vezes que se conjugar polaridades que deveriam permanecer separadas.

Nesse sentido, segundo a autora, o temor que os índios tinham, da quebra ou do roubo da pedra onde Sumé deixou as marcas de seus pés, por ocasião de sua partida do mundo dos homens, possivelmente se explicaria pelo medo do advento de um novo cataclismo causado pelo desaparecimento ou pela destruição do signo da separação entre seres humanos e heróis míticos. ${ }^{78}$

Nessa chave de leitura, a autora retoma a questão do encontro entre europeus e nativos: os primeiros seriam um elemento não previsto pelo mito e por isso deram início a:

“um longo e articulado processo de construção conceptual do outro e de revisão do eu a partir de situações históricas específicas e tendo em vista o universo simbólico fundador do mundo". 79

Nesse processo, segundo Pompa, houve diferentes maneiras do indígena lidar com o branco, sendo "a revisão total da cosmologia e a construção de um mundo

\footnotetext{
${ }^{77}$ POMPA, Cristina. Religião como tradução: missionários, Tupi e Tapuia no Brasil colonial. BauruSP: EDUSC, 2003. p.186.

${ }^{78}$ Ibidem, p.183-8.

${ }^{79}$ Ibidem, p. 188.
} 
novo" 80 a forma mais radical, já que a devastação trazida pelo outro foi reinterpretada "em termos de catástrofe cósmica que destruiu o mundo". ${ }^{81}$

Portanto, a idéia de futuro presente entre os Tupinambá, apreendida pela análise de Carneiro da Cunha e Viveiros de Castro, possivelmente foi inserida na cultura nativa a partir do contato entre nativos e missionários que forneceu novos elementos para os indígenas revisarem seu patrimônio simbólico. Nesse sentido, a idéia cristã de fim do mundo parece ter se associado aos mitos que tinham como tema os cataclismos que surgiam para instaurar uma nova ordem, ou por causa da destruição da ordem instituída, para apresentar uma solução mítico-ritual para a desordem instaurada.

Por fim, em relação ao tema da guerra, como veremos na análise do fragmento mítico registrado por d'Abbeville, o apontamento da vingança como tema da memória e articuladora do futuro entre os Tupinambá precisa ser contextualizado, ou restrito a um determinado período, já que, como veremos, possivelmente no Maranhão, na época em que os franceses lá se instalaram, esse já não parece ser o tema principal da memória, nem aquilo sobre o qual o futuro é projetado.

\section{A presença do outro no mito e no ritual guerreiro}

A revisão do patrimônio simbólico nativo a partir do encontro com a alteridade européia parece surgir nas narrativas Tupinambá sobre a origem da guerra que encontramos nas obras de Jean de Léry ${ }^{82}$ e de Claude d'Abbeville ${ }^{83}$ : nelas os europeus são incluídos nos motivos que deram origem ao sistema de vinganças indígena. Como veremos posteriormente, nesses textos, a personagem que originou a guerra entre os nativos (Léry), ou que contribuiu indiretamente para sua origem (d'Abbeville), pode ser associada à imagem do missionário. Além disso, a condenação da guerra indígena e a tentativa dos missionários de persuadir os indígenas a obedecerem ao Deus cristão estão presentes nos registros desse tema mítico.

Dessa forma, esses fragmentos míticos parecem relacionar aquele que é apontado pelas fontes como o valor primordial dos Tupinambá - a guerra - com o

\footnotetext{
${ }^{80}$ POMPA, Cristina. Op. Cit., p.189.

${ }^{81}$ Ibidem, p. 189.

82 LÉRY, Jean de. Viagem à Terra do Brasil. São Paulo: Martins/ Edusp, 1972. p.168.

${ }^{83}$ ABBEVILLE, Claude. Op. Cit., p.60-1.
} 
elemento fundamental da cultura missionária - a religião cristã -, tanto pelo fato da religião cristã constituir a principal linguagem de mediação entre europeus e indígenas na América portuguesa ${ }^{84}$, quanto por conta dos registradores dos mitos lerem a alteridade indígena nos termos da vertente cristã da qual eram adeptos.

Acreditamos que a presença de elementos do cristianismo propagado pelos jesuítas nessas narrativas seja o resultado das negociações culturais realizadas entre indígenas e missionários no período analisado: nos relatos sobre as missões jesuítas no Brasil, a condição imposta para a catequese e o batismo dos índios que queriam se tornar cristãos era que eles abandonassem seus antigos costumes de guerrear e de comer a carne de seus inimigos.

Como ocorriam casos de catecúmenos que incorriam no erro de retornarem aos antigos costumes, e por considerar o ato absurdo mesmo dentre os índios que ainda não tinham se convertido, os padres intervinham também nos rituais antropofágicos, tentando impedir a ocorrência da execução e/ ou batizar os prisioneiros. Navarro em uma carta que escreve da Bahia aos padres e irmãos de Coimbra, conta que em suas visitas às aldeias da região, procurava batizar os prisioneiros de guerra:

"Dali também íamos às aldeias a batizar a alguns que estavam para matar e comer, trazendo-los primeiro, segundo podia compreender sua capacidade, ao conhecimento da nossa santa fé, e ao consentimento do batismo". 85

Dois anos depois, em 1553, também na Bahia, o padre Brás Lourenço narra como o padre Vicente Rodrigues, com outro missionário da companhia, enfrentaram a ira dos indígenas, já que haviam batizado um prisioneiro de guerra sem o consentimento daqueles que executariam e comeriam o prisioneiro:

"Quis Nosso Senhor que passou por ali uma mulher gentil com uma cabaça de água, e pediram que lhes desse de beber, e um deles, fazendo que bebia, molhou um pano e com aquela água lhe batizou [o prisioneiro]. Percebendo, todavia, os gentis, com grande fúria começaram a gritar e as velhas os irritavam: 'não vês que os danam a

\footnotetext{
${ }^{84}$ POMPA, Cristina. Op. Cit.

${ }^{85}$ Carta do padre João de Alpilcueta Navarro escrita em 1551. In: LEITE, Serafim (S.I.) Cartas dos primeiros jesuítas do Brasil. v.1. São Paulo: Comissão do IV centenário da cidade de São Paulo. São Paulo: 1954. p. 279.
} 
carne?' E vindo com aquela grande fúria contra os padres e eles, com grande singularidade lhes mostraram caridade e amor" 86

Em 1555, em São Vicente, o padre Anchieta, junto com outros irmãos da Companhia, consegue impedir a execução de um prisioneiro na aldeia onde catequizava os índios. Para isso, os irmãos esconderam a corda de amarrar o prisioneiro e dificultaram o acesso do matador ao tacape, enfrentando o Principal da aldeia, que executaria o prisioneiro, durante o ritual e em reunião com os membros da aldeia. Nessa reunião, Anchieta conseguiu apoio dos familiares do Principal e de um ancião à sua intervenção. O Principal estava decidido a voltar aos antigos costumes, mas logo recuou em seu propósito, quando percebeu que não conseguiria apoio na aldeia, já que os índios de lá se mostravam firmes no propósito de não retornarem aos antigos costumes. ${ }^{87}$

Dessa forma, esses relatos narram a construção de uma cosmologia cristãtupi-colonial que parece ter influenciado os fundamentos do elemento central da cultura Tupinambá, seu sistema de vinganças, não apenas na narrativa dos mitos sobre a origem da guerra como também no ritual guerreiro, pois além da intervenção dos padres, havia também as proibições por parte da administração colonial das mortes cerimoniais dos inimigos, em contraposição ao estímulo da guerra entre os nativos, já que esta era uma fonte de escravos para os colonos.

Entretanto, devemos ter em conta que entre a narrativa registrada por Léry e aquela registrada por d'Abbeville decorreu mais de meio século: nesse período, o processo colonizador se intensificou e as missões no Brasil se consolidaram. Possivelmente, os índios com os quais Léry teve contato não participaram do processo de catequese, já que o primeiro registro da presença de missionários no Rio de Janeiro é de 1553: para lá foram alguns padres da Companhia de Jesus junto com Tomé de Souza, governador-geral do Brasil, para conhecerem a população indígena local e verificarem as condições para se construir ali uma povoação de portugueses. Segundo Leite, nessa expedição, os missionários foram recebidos somente pelos índios Temiminós, que eram amigos dos portugueses ${ }^{88}$.

\footnotetext{
${ }^{86}$ LEITE, Serafim. Op. Cit. p.517. (Carta original em espanhol)

${ }^{87}$ LEITE, Serafim (S.I.) Cartas dos primeiros jesuítas do Brasil. v.2. São Paulo: Comissão do IV centenário da cidade de São Paulo. São Paulo: 1954. p. 207-9.

${ }^{88}$ LEITE, Serafim (S.I.) Cartas dos primeiros jesuítas do Brasil. v.1. São Paulo: Comissão do IV centenário da cidade de São Paulo. São Paulo: 1954, p. 428-9.
} 
Por outro lado, parece não haver dúvidas de que os Tupinambá com os quais d'Abbeville teve contato, já conheciam o discurso missionário, pois, segundo Florestan Fernandes, provavelmente, eles eram migrantes da Bahia e de Pernambuco:

"os índios Tupi que povoavam os territórios compreendidos entre a Serra do Ipiapaba e o Amazonas procediam provavelmente da Bahia e de Pernambuco. Tiveram contatos prolongados com os portugueses e adquiriram um conhecimento íntimo do processo de desenvolvimento da colonização portuguesa. As migrações ocorreram em ondas sucessivas, depois de 1562. Primeiramente o movimento dirigiu-se para o interior; depois tomou a direção do norte, detendo-se na foz do Amazonas. Delas participaram principalmente índios Caeté e Tupinambá, sem que se possa excluir índios de outros grupos, como os Potiguar". ${ }^{89}$

Algumas passagens da obra de d'Abbeville parecem confirmar um contato mais intenso entre os índios do Maranhão, os colonos portugueses e os missionários. Dessas passagens, a mais significativa parece ser a de Momboré-açu, o único ancião que questionou a aliança que os franceses propunham, tendo como base de seu argumento o conhecimento que ele teve da colonização portuguesa:

"Vi a chegada dos peró em Pernambuco e Poitú (...) Mandaram vir os paí; e estes ergueram cruzes e principiaram a instruir os nossos e a batizá-los. Mais tarde afirmaram que nem eles nem os paí podiam viver sem escravos para os servirem e por eles trabalharem. Mas não satisfeitos com os escravos capturados na guerra, quiseram também os filhos dos nossos e acabaram escravizando toda a nação; $e$ com tal tirania e crueldade a trataram que os que ficaram livres foram, como nós,forçados a deixar a região". 90

Portanto, se o fragmento mítico sobre a origem da guerra registrado em d'Abbeville pode ser analisado como um dos produtos da negociação simbólica realizada entre jesuítas e indígenas durante a missão, a narrativa registrada em Léry parece não poder ser estudada a partir dessa hipótese. Todavia, acreditamos que, igualmente, no caso desse registro, o discurso religioso - o calvinista, ao invés do jesuíta - tenha sido a linguagem predominante tanto na comunicação entre o grupo de

${ }^{89}$ FERNANDES, Florestan. A organização social dos Tupinambá. São Paulo: Instituto Progresso Editorial, [1948]. p. 43.

90 d'ABBEVILLE, Claude. Op. Cit. p. 115. 
calvinistas ao qual Jean de Léry pertencia e os Tupinambá, quanto no próprio registro do fragmento mítico, já que a obra de Léry sobre sua viagem ao Brasil é escrita quase vinte anos depois dessa experiência. Nesse intervalo, o autor assistiu às perseguições religiosas aos huguenotes em seu país. Provavelmente, esse fato influenciou o referido registro.

Por fim, chama a atenção o fato desse tema mítico ter sido registrado somente pelas fontes francesas (conforme pudemos averiguar até o momento), a despeito do fato da maior parte das nossas fontes provirem das crônicas jesuítas. Dessa forma, investigaremos as causas do silêncio jesuíta em relação a esses mitos em contraposição à eloqüência francesa depois da análise dos referidos mitos. 


\section{CAPÍtulo 2 - A GUERrA E A ANTROPOFAGia SEGUNDO O Código CONTRUÍDO POR FRANCESES E INDÍGENAS NA FRANÇA ANTÁRTICA}

\section{Introdução}

"há muito tempo, não sei mais quantas luas, um mair como vós, e como vós vestido e barbudo, veio a este país e com as mesmas palavras procurou persuadir-nos a obedecer a vosso Deus, porém, conforme ouvimos de nossos antepassados, nele não acreditaram. Depois desse veio outro e em sinal de maldição doou-nos o tacape com o qual matamos uns aos outros; e há tanto tempo já o usamos que agora se desistíssemos desse costume as outras nações vizinhas zombariam de nós". ${ }^{91}$

Esta narrativa sobre a origem da guerra entre os Tupinambá integra o capítulo que Léry intitulou Religião dos selvagens da América; erros em que são mantidos por certos trapaceiros chamados caraíbas; ignorância de Deus. A presença inusitada desse mito no capítulo destinado a tratar da "religiosidade" indígena, ao invés daquele destinado a tratar da guerra tem uma explicação: o mito aparece como réplica de um ancião tupinambá às palavras de Léry sobre o Deus cristão. Nos comentários de Léry a esse registro estão presentes dois temas muito caros às teorias dos missionários cristãos sobre a religião dos americanos: a inconstância destes no cristianismo e a sua inserção dentre os gentios para os quais os primeiros apóstolos pregaram nos primórdios da Igreja cristã.

Por sua vez, a presença de um mair na narrativa indígena, exercendo o papel do herói cultural que dá origem ao sistema de vinganças indígena, demonstra que, tanto os indígenas quanto os europeus realizaram a sua leitura da alteridade a partir da inserção do outro nos quadros de uma realidade já conhecida. Como constatou Pompa a respeito dessa passagem da obra de Léry:

"Está claro aqui o jogo de espelhos que se estabelece entre padres e caraíbas, entre verdadeiros e falsos profetas, entre profecias cristãs sobre pregação aos gentios $e$ profecias nativas sobre a chegada dos brancos. Mais do que a uma coincidência de mitologias, estamos frente ao problema epistemológico da compreensão e, portanto da tradução das alteridades antropológicas no interior do quadro de uma história preestabelecida, de um e de outro lado: pelo mito do herói cultural e pela história

\footnotetext{
${ }^{91}$ LÉRY, Jean de. Op. Cit. P. 168.
} 
da salvação. Isto leva a uma curiosa coincidentia oppositum, que se expressa através de uma linguagem comum." 92

Portanto, consideramos esse fragmento mítico tupinambá sobre a origem da guerra um locus privilegiado para analisarmos, através da linguagem comum criada por franceses e nativos, tanto a leitura que os Tupinambá fizeram do elemento que lhes foi apresentado como o mais caro da cultura do outro - a religião cristã -, quanto a interpretação que os europeus fizeram do sistema de vinganças indígena, que nos primeiros anos das missões parecia constituir, como vimos anteriormente, um elemento importante da cultura tupinambá.

Uma breve comparação da leitura e da descrição que os missionários jesuítas, André Thevet e Jean de Léry fizeram da guerra indígena, sobretudo da antropofagia, nos auxiliará na identificação dos pontos comuns e das diferenças entre essas interpretações para, se possível, tentarmos compreender, por esse viés, por que as narrativas sobre a origem da guerra se concentram nas fontes francesas. Escolhemos esse caminho, pois observamos em nossas fontes que nas obras em que as descrições sobre a guerra e a antropofagia indígena eram sucintas - esse é o caso das obras dos missionários jesuítas -, inexistia qualquer referência sobre uma versão nativa sobre a origem da guerra.

Partimos da hipótese de que o projeto que o grupo ao qual estavam vinculados os autores desses relatos tinha para os indígenas influenciou a eloqüência de uns e o silêncio de outros sobre alguns aspectos da guerra e da antropofagia indígena. Em outras palavras, enquanto os missionários jesuítas faziam parte de um projeto de evangelização e inclusão dos nativos na "comunidade" católica, André Thevet e Jean de Léry, compunham um grupo para o qual a catequização do nativo ainda não fazia parte de seus projetos.

Além disso, uma comparação entre as interpretações de André Thevet e de Jean de Léry far-se-á necessária na medida em que estas se referem a um mesmo contexto (tanto francês quanto brasileiro) e que essas narrativas dialogam entre si, como assinalou Lestringant:

"As diversas partes da relação que Thevet publicara antes desta data [1578], as Singularidades de 1557 e a Cosmografia universal de 1575 irão servir a Léry de

${ }^{92}$ POMPA, Cristina. Op. Cit. p.56. 
rascunho para a sua própria obra. Escrevendo contra o cosmógrafo católico, mas também depois e a partir dele, Léry retém do mesmo quadro traçado por seu predecessor os traços essenciais: uma informação etnográfica exata e minuciosa; uma imagem indulgente e quase positiva do canibalismo tupinambá". ${ }^{93}$

Realizadas as etapas acima mencionadas teremos um esboço do contexto em que foi realizado o "jogo de espelhos", a que se refere Pompa, que propiciou a formulação de uma linguagem comum entre Tupinambá e franceses. Assim, teremos a base necessária para retomarmos a análise do fragmento mítico sobre a origem da guerra, privilegiando a simbologia indígena presente nesse registro, a partir da qual tentaremos desvendar os mecanismos através dos quais o estrangeiro teria sido inserido na origem do costume que parecia ser, naquele momento, o mais praticado pelos nativos.

No capítulo anterior vimos como a guerra indígena surgia, na visão dos missionários, como o principal obstáculo à conversão indígena, já que, se por um lado os nativos se mostravam muito dispostos a ouvirem o que os missionários tinham para lhes dizer, e se prontificavam a mudarem seus costumes para se tornarem cristãos, por outro, eles pareciam se esquecer facilmente o que haviam prometido e retornavam a seus antigos costumes de guerrear e de comer a carne de seus inimigos.

Como apontamos anteriormente, a queixa sobre a inconstância indígena no cristianismo também aparece no registro de Léry sobre a origem da guerra entre os Tupinambá. Léry, depois de ouvir as palavras do ancião sobre a origem da guerra nativa, respondeu aos indígenas que eles não deveriam se importar com a zombaria de seus vizinhos, pois se adorassem ao Deus cristão, venceriam todas as guerras. Após ouvirem estas palavras de Léry, os Tupinambá prometeram não comer mais carne humana e seguir os ensinamentos dos franceses. Além disso, se ajoelharam e ouviram a tradução realizada pelo interprete das preces francesas ${ }^{94}$. Contudo:

\footnotetext{
${ }^{93}$ LESTRINGANT, Frank. O canibal. Grandeza e decadência. Brasília: UnB, 1997. p.103.

${ }^{94}$ LÉRY, Jean de. Op. Cit. p. 168.
} 
"Depois dessa cena levaram-nos os selvagens para que repousássemos em redes de algodão, mas antes de começarem a dormir já os ouvimos cantar todos juntos que para se vingarem de seus inimigos deviam aprisionar e comer o maior número possivel. Eis um belo exemplo da inconstância desse povo e da natureza corrupta do homem". ${ }^{95}$

Se neste trecho, Léry repete uma das principais queixas dos missionários jesuítas sobre a inconstância indígena no cristianismo, devemos verificar que a própria resposta de Léry às palavras do ancião estimulou os indígenas a entoarem seus cânticos de exortação à guerra, já que ele afirma que em troca da obediência, o Deus cristão os auxiliaria a ganharem todas as guerras.

Essa fala parece refletir o fato de que a relação entre os franceses e as guerras indígenas diferia da relação entre os jesuítas e as referidas guerras, pois apesar dos jesuítas algumas vezes utilizarem as promessas feitas pelos caraíbas para atraírem os indígenas para o catolicismo, prevalecia em seus discursos a condenação da vingança indígena, que era por eles classificado como o pior dos maus costumes nativos. Em contrapartida, alguns franceses, sobretudo os intérpretes, participavam das guerras inter-tribais. Essa participação, segundo Perrone Moisés, constituía parte de um "sistema" peculiar de relação com a alteridade:

“O 'sistema' francês caracterizar-se-ia, assim, pela cuidadosa manutenção das alianças, por meio de presentes e de apoio militar efetivo nas guerras, pela institucionalização do envio de jovens que serviam de intermediários, pela residência junto aos índios (tanto desses jovens como de missionários), pela realização de grandes conferências e feiras de comércio em aldeias aliadas (e não apenas em núcleos franceses). Essas eram as especificidades francesas. Nisso consistia o 'segredo' que lhes permitia manter a amizade dos povos aliados $e$ 'controlar', indiretamente, enormes territórios."

Contudo, alguns elementos desse "sistema" diferenciado de relação entre franceses e americanos, de que nos fala Perrone Moisés, coincidiam, no caso brasileiro, com os elementos presentes na relação entre os colonos portugueses e os

\footnotetext{
${ }^{95}$ LÉRY, Jean de. Op. Cit. p.168.

96 PERRONE-MOISÉS, Beatriz. Relações Preciosas: franceses e ameríndios no século XVII. Tese. Orientadora: CUNHA, Manuela Carneiro da. Universidade de São Paulo, jul./1996. p.109.
} 
grupos indígenas com os quais eles estabeleciam aliança. Nos primeiros anos de colonização, a aliança com a população nativa foi de suma importância para a sobrevivência do português na colônia: era através do escambo e das negociações com os chefes indígenas que os portugueses obtinham gêneros alimentícios e mãode-obra. Esta última poderia ser obtida tanto pelo escambo com produtos europeus, quanto pela compra dos cativos de guerra. Mas como destaca John Monteiro, com o passar do tempo essa forma de obtenção de mão de obra nativa se mostrou pouco eficiente para atender às demandas européias. Assim, as guerras intertribais assumiram uma outra função: capturar escravos para as empresas coloniais. ${ }^{97}$

A primeira experiência francesa de colonização do Brasil (a França Antártica), durou apenas cinco anos. Nesse período, o meio dos franceses obterem mão-de-obra nativa se assemelhou muito ao modo português no início da colonização: o escambo ou a compra dos cativos de guerra. Esse fato pode ser averiguado no relato de Jean de Léry, quando ele transcreve a fala de um índio que lhe vendeu uma mulher com seu filho:

"Não sei o que vai acontecer no futuro, depois que pai Colá ${ }^{98}$ chegou aqui já não comemos nem a metade de nossos prisioneiros". 99

Dessa forma, a presença francesa entre os Tupinambá da Guanabara trouxe alterações no sistema de vinganças, além daquelas já causadas pela colonização portuguesa, que não se restringiram à presença de combatentes estrangeiros e ao conhecimento de novas armas de guerra, mas implicou também em um novo destino para parte dos cativos de guerra: provavelmente, um dos motivos que levaram os franceses a condenarem o sistema de vinganças indígena era a necessidade que eles tinham de escravos para a nova colônia.

Além disso, os franceses não eram os únicos estrangeiros que tinham homens vivendo entre a população nativa, segundo os costumes desta, participando, inclusive de suas guerras. Em suas cartas, os missionários contam sobre os resgates que fizeram de portugueses que viviam nas aldeias segundo os costumes indígenas:

\footnotetext{
${ }^{97}$ MONTEIRO, John. Negros da terra: índios e bandeirantes nas origens de São Paulo. São Paulo: Companhia das Letras, 1994. p.33

${ }^{98}$ Nicolas Villegagnon, segundo nota do texto.

${ }^{99}$ LÉRY, Jean de. Op. Cit. p. 145.
} 
"Muitos poucos dias faz que o Padre Leonardo Nunes e seis Irmãos, dentre os quais eu era um, íamos para dentre os índios, onde fomos buscar um cristão que fazia uns oito ou nove anos que andava por lá feito índio com eles". ${ }^{100}$

O homem de quem fala Pero Correia aceitou ser resgatado pelos missionários junto com sua mulher e suas filhas, porém, segundo o padre Leonardo Nunes, ele parecia não se lembrar mais da doutrina cristã:

“A ele, não tenho ainda confessado porque de todo tinha já estragado o juízo, tanto que nas primeiras prédicas que lhe fiz tenho para mim que não entendia as coisas que falava de Deus nosso Senhor (...) nem na igreja entra, senão à força, nem pudemos convencer a ele que se pusesse de joelhos diante do Santíssimo Sacramento". ${ }^{101}$

O padre Diogo Jácome, em seu comentário à expedição de resgate desse "cristão" que vivia entre os índios, nos conta sobre o encontro de um outro homem que vivia entre os índios:

“ (...) agora há poucos dias que partiu daqui com cinco Irmãos para outra parte ao longo do mar, obra de XXX léguas em busca de um homem casado em Portugal, o qual estava entre os índios há oito ou nove anos". ${ }^{102}$

Contudo, o fato desse acontecimento ter sido comentado por vários missionários, juntamente com a pesquisa das nossas fontes primárias, talvez demonstre que existiam muito mais franceses vivendo entre os índios do que portugueses. Na França Antártica, um grande número de intérpretes franceses vivia entre os índios, adotando seus costumes: esse fato pôde ser constatado através da notícia sobre a rebelião contra Villegagnon, chefe da referida colônia, liderada por um intérprete. Fracassada a rebelião, seu líder foge com aproximadamente vinte e cinco outros intérpretes. ${ }^{103}$

\footnotetext{
${ }^{100}$ Carta do Irmão Pero Correia [ao padre Simão Rodrigues], escrita de S. Vicente, em 1551. IN: LEITE, Serafim. Op. Cit., v.1, p.230.

${ }^{101}$ Carta escrita de S. Vicente em 1551. In: LEITE, Serafim. Op. Cit. p. 235.

${ }^{102}$ Carta escrita de S. Vicente em 1551. In: LEITE, Serafim. Op. Cit. p. 244.

${ }^{103}$ HOLANDA, Sérgio B (org.). História geral da civilização brasileira. T.1, V.1. São Paulo: Difel. p. 151
} 
Portanto, se os franceses, se assemelhavam aos portugueses nos primeiros anos da colonização, havia algumas diferenças entre uns e outros, no que diz respeito à relação com os nativos: acreditamos que a participação direta nas guerras indígenas era muito maior entre os franceses do que entre os portugueses, assim como a adoção dos costumes nativos.

Todavia, é importante destacar que uma relação mais próxima com os indígenas dependia do papel do francês na colônia: nesse sentido, os intérpretes eram os homens mais próximos dos índios, já que adotavam seus costumes e que participavam de fato de suas guerras. Como lastimou Léry:

“Com pesar sou, porém, forçado a reconhecer aqui que alguns intérpretes normandos, residentes há vários anos no país tanto se adaptaram aos costumes bestiais dos selvagens que, vivendo como ateus, não só se poluíam em toda espécie de impudícias com as mulheres selvagens, mas ainda excediam os nativos em desumanidade, vangloriando-se mesmo de haver morto e comido prisioneiros". ${ }^{104}$

Por sua vez, tudo indica que alguns calvinistas também desenvolveram uma relação mais próxima com os indígenas, por necessidade, já que fugiam das perseguições de Villegagnon.

Esse fato pode ser constatado pela comparação dos juízos de Thevet $^{105}$ e de Jean de Léry ${ }^{106}$ sobre o sistema de vinganças indígenas. Nos relatos desses autores vemos modos aparentemente distintos de se conceber a antropofagia (o ato desse sistema mais condenado pelos europeus): enquanto o primeiro, por meio da comparação, enfatiza que trata-se de um costume presente dentre alguns povos "bárbaros", o segundo possui uma relação ambígua com a guerra, ora condenando-a, ora amenizando a barbaridade outrora afirmada, por meio da comparação das “selvagerias" praticadas pelos Tupinambá com aquelas praticadas pelos seus conterrâneos nas guerras religiosas as quais assistiu.

Como apontamos anteriormente, acreditamos que através da comparação dessas duas interpretações sobre o sistema de vinganças indígena teremos mais uma chave de leitura para a versão de Léry da narrativa sobre a origem da guerra entre os

\footnotetext{
${ }^{104}$ LÉRY, Jean de. Op. Cit. p. 153.

105 THEVET, André. As singularidades da França Antártica. Belo Horizonte: Itatiaia/ São Paulo: Edusp, 1978.

${ }^{106}$ LÉRY, Jean de. Op. Cit.
} 
Tupinambá. Essa comparação é necessária, pois ambos os autores se baseiam nas palavras dos intérpretes para comporem seus textos sobre os Tupinambá e viveram, em lados e circunstâncias distintas, o mesmo contexto das guerras religiosas francesas, além do fato, já apontado anteriormente de Léry utilizar a obra de Thevet tanto como contraponto quanto como base de sua obra.

\section{André Thevet}

As diferenças entre as concepções de Léry e de Thevet sobre o sistema de vinganças nativo possuem estrita relação com a posição que estes autores ocuparam na colônia e posteriormente, na França no contexto das guerras religiosas. Thevet veio ao Brasil como cronista oficial da colônia brasileira e, durante as dez semanas que esteve aqui (entre o final de 1555 e o início de 1556), não teve atrito nenhum com Villegagnon, jurando, segundo acusações de Léry, e de Sebastién Münster, fidelidade ao credo protestante, quando Villegagnon ainda não havia rompido com o calvinismo.

$\mathrm{Na}$ França, quando chegaram as notícias sobre as disputas religiosas ocorridas entre Villegagnon e os huguenotes na colônia, Thevet já havia se desvencilhado publicamente das opiniões comprometedoras de Villegagnon. Em 1558, sob a proteção dos La Rochefoucauld, ele publica As singularidades da França Antártica. Com esta obra ele consegue prestígio junto ao rei Henrique II, sendo nomeado cosmógrafo do rei, em 1560. Durante o reinado de Catarina de Médicis, ele conserva seu título honorífico, fato que lhe garantiu a proteção da rainha durante as guerras religiosas, e a publicação de suas obras. ${ }^{107}$

Dessa forma, a vivência que Thevet teve dos conflitos religiosos franceses cujas disputas, segundo Lestringant, se iniciaram no continente americano ${ }^{108}-$ foi muito diferente da experiência de Léry, da qual falaremos adiante. Thevet, por contar com a amizade de Villegagnon (na colônia) e, posteriormente, com a proteção de Catarina de Médicis durante as guerras religiosas, não poderia conceber o selvagem como o termo para a realização de uma auto-crítica à própria sociedade.

\footnotetext{
${ }^{107}$ LESTRINGANT, Frank. Le huguenote et le sauvage. L'Amerique et la controverse coloniale em France, au temps des Guerres de Religion (1555 - 1589). Paris: Aux Amateurs de Livres, 1990. p.401.

${ }^{108}$ Ibidem, p.32
} 
Possivelmente, por isso, Thevet pareceu ser menos complacente que Léry com os costumes indígenas, já que não tinha motivos para formular uma crítica a seus conterrâneos a partir da comparação destes últimos com os indígenas que conhecera na Guanabara. Assim, o Tupinambá se torna, como afirmou Lestringant, um termo de comparação universal com os povos não-europeus ${ }^{109}$, sendo nivelado não só a estes povos, como também aos europeus de um passado longínquo ${ }^{110}$. Dessa forma, Thevet traça uma linha de continuidade entre índios e europeus, como o fizeram os primeiros teóricos que questionaram a pertença dos americanos à humanidade, tal qual ela foi concebida pela cristandade européia, ou seja, inserindo os americanos no início da escala de classificação das populações humanas.

O resultado é uma visão do selvagem aparentemente menos complacente e mais fragmentada que a visão de Léry, já que ela tem como ponto de referência as várias alteridades que se apresentaram ao europeu naquele período, como nos mostra Lestringant:

"Segundo Thevet, o selvagem não é mais que a soma de traços particulares e circunstanciais, isto é, ele condensa em si mesmo um catálogo de 'singularidades' irredutíveis e contraditórias: cruel e debochado, virtuoso e hospitaleiro, homem honrado e "grande ladrão" etc. Os qualificativos que lhes são atribuídos alternada ou simultaneamente parecem ser regulados por um código em constante mudança que se pauta, em cada detalhe, pela particularidade que está sendo destacada"111.

Assim, na descrição que Thevet realiza do sistema de vinganças indígena, cada etapa possui o seu termo de comparação com as alteridades histórica e antropológica. A troca de injúrias entre os inimigos indígenas antes da batalha é comparada a uma antiga tática romana de guerra, que foi posteriormente adotada pelos gauleses. Já quando trata da antropofagia, considerada pelo autor como "a mais cruel e indigna" das vinganças praticadas pelos nativos, Thevet enfatiza que esta era uma antiga prática dos turcos, mouros e árabes. ${ }^{112}$ Mais adiante, em um capítulo

\footnotetext{
109 LESTRINGANT, Frank. Mitológicas: a invenção do Brasil. Revista USP, p.204-5.

${ }^{110}$ Ibidem, p. 211.

${ }^{111}$ LESTRINGANT, Frank. À espera do outro. Nota sobre a antropologia da Renascença. Um desafio ao espírito de sistema. In: NOVAES, Adauto. A outra margem do Ocidente. Brasília-DF, MINC FUNARTE, São Paulo: Companhia das Letras, 1999. p. 37

112 THEVET, André. Op. Cit., p.127-8.
} 
destinado a tratar especificamente da antropofagia tupinambá, Thevet inclui outros povos não cristãos dentre adeptos dessa prática:

"A História não nos fala de nenhuma outra nação que tenha sido tão bárbara e que tenha tratado seus inimigos com uma tão excessiva crueldade. Sabe-se apenas, de acordo com os escritos de Josefo, que houve algo semelhante em Jerusalém quando os romanos ali chegaram. Após terem seus habitantes dado cabo de todos os víveres, a terrivel fome que se seguiu obrigou as mães a matar seus filhos e devorá-los! Conhecem-se também os antropófagos da Cítia, que se alimentam de carne humana, assim como estes que ora descrevo". ${ }^{113}$

A inclusão posterior dos judeus e dos citas dentre os antropófagos pode ser explicada pela participação de um colaborador, Mathurin Héret, na composição dessa obra $^{114}$ e pela própria concepção fragmentada que Thevet tinha do selvagem que, como vimos, era comparado com as alteridades antropológica e temporal. Todavia, se essa comparação permitiu, como destacou Lestringant, incluir os selvagens na história humana ${ }^{115}$, o trecho acima exposto parece demonstrar que um dos objetivos de Thevet era destacar a inferioridade dos povos que foram nivelados aos Tupinambá. Um exemplo pode ser dado pela inclusão dos judeus dentre os "canibais": em nenhum momento Josefo fala da prática da antropofagia dentre os judeus em seu relato sobre o cerco de Jerusalém pelos romanos. O que ele faz é interpretar essa guerra como um castigo divino pela desobediência de seus conterrâneos. ${ }^{116}$

Nessas associações realizadas por Thevet, ou por seu colaborador, entre os Tupinambá e os outros "bárbaros", o tema do canibalismo aparece ligado à não pertença dos povos acusados dessa prática à cristandade católica e, portanto, à não obediência desses povos à "verdadeira divindade" (esse tema surge no fragmento mítico sobre a origem da guerra registrado por Léry). Assim, nos trechos em que são realizadas essas comparações prevalece a condenação cristã dessa prática que é interpretada como uma prática alimentar. Essa interpretação parece enfatizar a selvageria daqueles que a praticam ou que já a praticaram. Quando a antropofagia

\footnotetext{
113 THEVET, André. Op. Cit., p.132-3.

${ }_{114}^{114}$ LESTRINGANT, Frank. Op. Cit., p.41.

${ }^{115}$ LESTRINGANT, Frank. O canibal. Grandeza e decadência. Brasília: UnB, 1997. p.90.

${ }^{116}$ ROCHA, Ivan E. Dominadores e dominados na Palestina do século I. Revista História. Assis: Unesp, nov.2004.
} 
tupinambá é assim interpretada ela é explicada pela incapacidade de distinção do indígena entre o comestível e o não comestível:

"Pode-se facilmente deduzir que a incivilidade dessa boa gente no que concerne aos seus hábitos alimentares é a mesma que demonstram em relação a tudo o mais. E como não possuem algum critério que lhes permita escolher o que é bom, separando-o daquilo que não presta, comem de todas as carnes, a qualquer dia e hora, sem moderação alguma." 117

Contudo, quando Thevet se restringe à descrição do sistema de vingança indígena, ele enfatiza sua característica de vingança, deixando de lado a interpretação desta como uma prática alimentar:

"Se o leitor perguntar por que estes selvagens fazem guerras uns contra os outros, conquanto quase não existam entre eles diferenças hierárquicas, nem riquezas que despertem cobiças, e sendo que a terra lhes concede até mais do que necessitam, só poderia responder-lhe que as causas de tais guerras são absolutamente fúteis. Move-os apenas o mero apetite de vingança, e nada mais, tal e qual se fossem animais ferozes. Como uma desculpa para sua impossibilidade de selarem um acordo honesto, alegam que seus vizinhos e eles têm sido inimigos desde todo o sempre..."

Através dos registros supra-citados, podemos deduzir que independentemente da interpretação dada por Thevet à antropofagia indígena - hábito alimentar ou vingança -, ela é considerada um ato selvagem, de povos que desconhecem a civilização: no caso em que Thevet a considera como uma prática alimentar, ela é explicada pelo fato dos indígenas desconhecerem as diferenças entre alimentos e não alimentos; já quando ela é interpretada como vingança, ela é nivelada a ação dos animais ferozes. Dessa forma, as referidas afirmações, são unânimes em condenar esse costume, excluindo-o do rol das práticas aceitáveis dentre os homens civilizados.

Além disso, Thevet, ao legar esse costume ao passado dos outros "bárbaros", enfatiza que a antropofagia indígena constitui um costume sem comparação sincrônica fora da América. Assim, se por um lado ela é usada para enfatizar a "barbárie" dentre alguns povos não cristãos, por outro ela destaca que os indígenas

${ }^{117}$ THEVET, André. Op. Cit. p.105. 
brasileiros possuem o pior costume dentre os povos bárbaros contemporâneos de Thevet. Por isso, não acreditamos, como o faz Lestringant, que, quando Thevet interpreta a antropofagia como vingança, ele esteja apenas a reconhecendo como uma atividade humana comum a alguns povos não cristãos $^{118}$, para nós, inclui-se também e contraditoriamente nessa interpretação, a classificação de todos os seus praticantes na escala mais próxima dos animais, em um sistema classificatório que estabeleceu uma hierarquia entre os diferentes povos humanos, depois dos primeiros contatos com as alteridades americanas.

Essa forma de conceber o sistema de vinganças indígenas aproxima Thevet dos jesuítas e de alguns dominicanos. Francisco de Vitoria, um dominicano que ocupou a primeira cadeira de teologia na Escola de Salamanca entre 1529 e $1546^{119}$, também concebe a antropofagia como o pior dos costumes indígenas e a associa, como Thevet, a uma prática alimentar, que ocorre porque os indígenas não saberiam distinguir alimentos e não alimentos.

Vitoria inicia sua análise do canibalismo a partir da premissa de que se tratava de um costume contrário às leis humanas e às leis naturais ${ }^{120}$. Essa premissa parte da concepção cristã de Vitoria sobre as leis da natureza, o homicídio e a necessidade da integridade do corpo dos mortos:

"O homem, que está nos limites do mundo espiritual e do mundo natural, é uma criatura de Deus, por isso só Deus (e as criaturas que vivem no paraíso) são mais perfeitos que ele. Assim, o homem não pode pertencer a nenhum outro ser a não ser a Deus. Alguns homens podem se sujeitar a outros homens de uma forma que não comprometa sua liberdade de forma absoluta; mas, embora escravos, eles não 'pertencem' a seus senhores como os membros dos estágios sub-humanos. E porque eles não pertencem a seus senhores, não podem ser comidos por eles. A ordem social que determina a relação de um homem com outro é natural e, portanto, modelada na hierarquia natural (...) Os homens permanecem homens mesmo quando são escravos". ${ }^{121}$

\footnotetext{
${ }^{118}$ LESTRINGANT, Frank. O canibal. Grandeza e decadência. Brasília: UnB, 1997. p.87.

${ }^{119}$ PAGDEN, Anthony. The fall of natural man. Cambridge: Cambridge University Press, 1988. p.60.

${ }^{120}$ Ibidem, p.84-5.

${ }^{121}$ Ibidem, p. 86.
} 
Portanto, segundo Vitoria, Thevet e praticamente todos os europeus que descreveram e analisaram esse costume, a antropofagia é o pior dos costumes, pois constitui uma prática não humana e contrária às leis da natureza e que, por isso, situa seus praticantes, em relação à hierarquia dos grupos sociais, na área mais inferior dessa escala. Todavia, a humanidade do americano não é negada por esses autores, mesmo tendo-se em vista o fato deles praticarem um ato contrário às leis naturais, já que a ocorrência dessa prática é explicada pelo desconhecimento que os nativos tinham dessas leis.

Dessa forma, a imagem que Thevet fornece da antropofagia tupinambá, apesar de ser a mais completa - ele acrescenta mais detalhes sobre esse costume no decorrer de suas obras - se insere no quadro já desenhado por outros autores da sua época que teriam supostamente presenciado esse ato. Esses relatos baseiam-se em padrões encontrados em contos cristãos sobre populações não-cristãs - dentre elas os judeus - nos quais esses povos além de comerem seres de sua própria espécie, também não respeitariam nem o tabu do incesto, nem as linhas tradicionais de demarcação social $^{122}$. Tais acusações, verdadeiras ou não, serviram para colocar o outro numa escala inferior da hierarquia humana.

Dessa forma, se Thevet oscila, em sua descrição do selvagem brasileiro, entre humanização e barbarização, podemos dizer que, certamente os aspectos da cultura indígena que ligam o nativo à humanidade e, sobretudo à "verdadeira" humanidade cristã, estão muito longe do sistema de vinganças indígena, já que, além desse costume só ser encontrado dentre os outros povos "bárbaros", ele é interpretado como um ato no mínimo incivil, independentemente dele ser associado à alimentação ou a vingança.

Como veremos, por meio da análise da concepção de Léry, a "selvageria" desse ato só será amenizada quando ele servir para se pensar criticamente a própria sociedade. Contudo, mesmo assim, a antropofagia não perderá o seu aspecto de incivilidade e, por isso, não deixará de ser condenada.

${ }^{122}$ PAGDEN, Anthony. Op. Cit. p.82. 
Jean de Léry

Como apontamos anteriormente, a vivência de Léry das disputas religiosas entre huguenotes e católicos na França e na França Antártica tiveram grande contribuição para sua interpretação sobre a vingança indígena e o seu ritual mais condenado - a antropofagia. Dessa experiência conturbada resultou a construção de uma imagem do "selvagem" que serviu de contra-peso na crítica que Léry realizou da própria civilização. Nessa crítica, Léry retomou o costume que caracterizava os Tupinambá como alteridade absoluta - a antropofagia - para mostrar que o mesmo não era tão estranho dentre os cristãos do Velho Mundo quanto se dizia em todos os relatos sobre a América.

As bases dessa relativização da antropofagia indígena foram lançadas no contexto dos debates entre Villegagnon e os huguenotes sobre o dogma da Eucaristia (em 1556) ${ }^{123}$ e retomadas quando Léry se deparou novamente com a antropofagia na França, durante o cerco de Sancerre (em 1573) ${ }^{124}$. Portanto, essa idéia se constituiu a partir de uma primeira postura crítica proporcionada pela crise de identidade pela qual passava a França, por conta das disputas religiosas entre huguenotes e católicos e do confronto com a novidade representada pelo homem americano.

Essa crise atravessa toda a primeira experiência francesa de colonização no Brasil. Os desacordos internos ocorridos na França Antártica, primeiramente com os intérpretes normandos, e depois com os huguenotes, parecem ter sido gerados pela luta do idealizador da colônia, Villegagnon, para extirpar as alteridades antropológica e religiosa, a partir de uma base comum - a sua concepção da religião cristã, que oscilou entre o catolicismo e o calvinismo.

Essa idéia nos foi sugerida pelos estudos de Frank Lestringant já mencionados e pela leitura do relato de Léry sobre as dissidências entre o seu grupo, os huguenotes, e Villegagnon. Nesses textos, a opinião de Villegagnon sobre o dogma da Eucaristia parece compor a primeira relativização que Léry realiza da antropofagia tupinambá. Uma prévia análise do fragmento mítico sobre a origem da guerra entre os Tupinambá transcrito por Léry, sugere que, se houveram divergências entre Léry e Villegagnon a respeito do referido dogma, ambos compartilharam

\footnotetext{
${ }^{123}$ LESTRINGANT, Frank. Le huguenote et le sauvage. L'Amerique et la controverse coloniale em France, au temps des Guerres de Religion (1555 - 1589). Paris: Aux Amateurs de Livres, 1990, p.32.

${ }^{124}$ LESTRINGANT, Frank. O canibal. Grandeza e decadência. Brasília: UnB, 1997. p.113.
} 
alguns juízos sobre o indígena. Por isso, é importante retomar as concepções de Villegagnon sobre o índio e sobre a Santa Ceia.

Em relação à alteridade indígena, Villegagnon, compartilhou das opiniões, em voga no período. Laura de Mello e Souza, em seu estudo sobre as raízes da demonização do Novo Mundo constata três níveis por meio dos quais foram expressos os juízos europeus sobre o homem americano: "como uma outra humanidade, como animais, e como demônios" ${ }^{125}$, enfatizando que esses juízos "Não seguem uma ordenação cronológica (...) mas se alternam ao mesmo tempo" ${ }^{126}$. Assim, encontramos esses três níveis na opinião de Villegagnon sobre o indígena: a animalização do índio está presente na sua escravização, justificada nesse caso pela obrigação determinada por Deus do índio servir ao europeu. Na sua concepção da colonização da América como uma missão dada por Deus para que se convertessem os últimos gentios, imbricam-se duas concepções sobre o indígena: como uma outra humanidade, a ser resgatada, e como ministros do Diabo, por serem por ele dominados. Esse ponto de vista pode ser apreendido na oração feita por Villegagnon por ocasião da primeira celebração da Santa Ceia no forte Coligny:

"Rendo-te graças, meu Deus, de todo o coração, por te haveres dignado tirar-me do mundo em que vivia, por ambição, para colocar-me no lugar onde com toda liberdade e todas as minhas forças eu possa contribuir para o aumento de teu reino (...) Eu te agradeço ainda, ó Deus de suprema bondade, porque, conduzindo-nos a este país de ignorantes de teu nome e grandeza, tu me preservastes da malícia de Satanás e tu lhes incutiste terror a ponto de, à simples menção de teu nome, tremerem de medo. Tu os obrigaste a alimentar-nos com seu trabalho e para refrear a sua brutal impetuosidade os afligiste com cruéis moléstias, preservando-nos delas, entretanto. Suprimiste os que nos eram mais perigosos e reduziste os outros a tal estado de fraqueza que nada ousam contra nós". ${ }^{127}$

Aqui, como no caso dos jesuítas, o horror à guerra tupinambá e a condenação cristã de seus motivos pareceram constituir as causas principais da demonização do índio. Contudo, outro fato parecia assustar Villegagnon: era a participação dos

\footnotetext{
${ }^{125}$ SOUZA, Laura de Mello e. Op. Cit, p.56.

${ }^{126}$ Ibidem.

${ }^{127}$ LÉRY, Jean de. Op. Cit. p. 55. Essa oração, presente no relato de Léry sobre sua viagem ao Brasil foi, segundo ele, transcrita literalmente de uma cópia que ele obteve.
} 
intérpretes franceses nessa guerra ${ }^{128}$. Dessa forma, durante o mesmo evento, ao final da primeira oração:

"Da mesma forma concede-nos a graça para que perdoemos os que nos ofendereme procuremos o seu bem em vez de vingar-nos, como se fossem nossos amigos, seguindo assim o exemplo de teu filho que pediu por aqueles que o perseguiam. (...) Nós te rogamos ainda, pai celestial, que nos guarde das tentações com que Santanás busca desviar-nos; preserva-nos de seus ministros e dos selvagens insensatos entre os quais te aprouve jogar-nos e conserva-nos: livra-nos dos apóstolos da religião cristã espalhados entre eles ${ }^{129}$ e chama-os à tua obediência a fim de que se convertam, de que teu evangelho se torne conhecido em toda a terra, e em todas as nações se proclame a tua boa-aventurança.",130

Nesse trecho, vemos através do pedido de proteção contra os "selvagens insensatos", os "ministros de Satanás", e os intérpretes normandos, feito logo após a solicitação da graça do perdão (ao invés da vingança), o medo da disseminação do locus da cultura do outro na colônia. Esse temor talvez explique os desentendimentos entre Villegagnon e os intérpretes franceses que culminou na proibição do casamento entre franceses e indígenas.

Como destaca Lestringant, foi por causa da reação dos colonos mediante essa proibição, acrescida da observação de que muitos de seus colegas viviam como índios, que Villeganon resolveu solicitar a imigração huguenote. Contudo, estes também representavam uma alteridade, já que não eram católicos. Dessa forma, logo iniciaram-se novas dissidências, só que desta vez, entre diferentes pontos de vista cristãos, ou seja, entre a concepção dos pastores huguenotes e a concepção católica de Villeganon sobre os alimentos presentes na Santa Ceia ${ }^{131}$. As palavras de Villegagnon que causaram o início de tais divergências estão presentes nas orações feitas durante a primeira comemoração da Santa Ceia, já mencionadas. Através delas, temos a defesa de Villegagnon da presença real de Cristo no pão e no vinho presentes nessa celebração:

\footnotetext{
${ }^{128}$ Ibidem, p. 153.

${ }^{129}$ Segundo nota de Léry, estes eram os intérpretes normandos que moravam entre os índios antes da chegada de Villegagnon, e a ele não se submetiam.

${ }^{130}$ LÉRY, Jean de. Op. Cit. p.57.

${ }^{131}$ LESTRINGANT, Frank. A outra conquista: os huguenotes no Brasil. In: NOVAES, Adauto (org.) A descoberta do homem e do mundo. Brasília: MINC-FUNARTE; São Paulo: Companhia das Letras, 1998. p.421.
} 
"E assim como a carne terrestre se converte em sangue e alimento do corpo, assim também nutre e sustenta as nossas almas com a carne de teu filho, até que ele se consubstancie em nós e nós nele (...) e se te ofendermos permite, senhor de misericórdia, lavarmos os nossos pecados no sangue de teu filho, lembrando-te de que fomos concebidos na iniquiidade e de que pela desobediência de Adão em nós reside o pecado (...)"132

Segundo Léry, ao término dessas orações seguiram-se as discussões entre Villegagnon e os pastores protestantes que, ao contrário de Villegagnon, acreditavam na presença simbólica do sangue e do corpo de Cristo no vinho e na hóstia.

A partir desse primeiro desentendimento entre Villegagnon e os novos colonos, seguiu-se a ruptura entre ambos: os segundos, argumentaram que outrora trabalharam duro com o intuito de construir uma colônia protestante no Brasil, contudo, se Villeganon não seguia o credo protestante, eles não tinham motivos para obedecê-lo. Mediante a represália do chefe da colônia, Léry e alguns colegas fugiram para o continente, vivendo entre os índios (e graças ao auxílio destes) até terem a oportunidade de retornarem a França ${ }^{133}$.

No comentário de Léry que se segue à exposição dos desentendimentos entre seu grupo e Villegagnon, a opinião deste último sobre os elementos da Eucaristia constituiu as bases para a primeira relativização da antropofagia indígena, realizada na obra de Léry, segundo ele, Villegagnon e João Cointa (o colono que parece compartilhar a opinião de Villegagnon):

"Queriam assim embora sem saber como fazê-lo, comer a carne de Jesus Cristo, não só espiritualmente, mas ainda materialmente, à maneira dos selvagens guaitaká, que mastigam e engolem a carne crua." 134

Ou seja, como afirmou Lestringant, segundo o ponto de vista de Léry, a antropofagia de Villegagnon é mais selvagem que a dos Tupinambá, que comem a

\footnotetext{
${ }^{132}$ LÉRY, Jean de. Op. Cit. p.56

${ }^{133}$ LÉRY, Jean de. Op. Cit. p.64.

${ }^{134}$ Ibidem, p.58.
} 
carne do inimigo cozida e comparável a antropofagia de seus inimigos, que por comerem cru eram mais selvagens que eles. ${ }^{135}$

Se nesse trecho Léry, situa Villegagnon abaixo dos Tupinambá, em relação a seu costume mais condenado, mais adiante ele volta a condenar os costumes indígenas, aprovando Villegagnon, em sua perseguição aos intérpretes normandos que constituíram família com as mulheres indígenas e no fato dele ter proibido o casamento entre franceses e indígenas não convertidas, já que neste caso, a "lei encontrava claro fundamento na palavra de Deus". ${ }^{136}$

Dessa forma, se houve desentendimentos relativos às divergências de interpretação do sacramento, parece ter havido acordo, como veremos adiante, na demonização do índio.

Mais tarde, perto da data em que Léry decide escrever o relato de sua viagem ao Brasil e, provavelmente, estimulando sua escrita, Léry presencia, durante o cerco de Sancerre, a um novo episódio de canibalismo: uma menina morta serve de alimento a seus familiares. ${ }^{137}$ Também em Sancerre, um homem questiona Léry, que era então pastor, se "faria mal ou ofenderia a Deus, se ele comesse em extrema necessidade, das nádegas que lhe parecia tão saborosa, de um homem que fora morto". ${ }^{138}$ Segundo Lestringant esses episódios chocam Léry mais do que a antropofagia tupinambá. Assim, saindo vitoriosos aqueles que cercavam a cidade, Léry entrega a seu opositor, o líder do cerco, um relato sobre a antropofagia que lá ocorreu.

Temos assim brevemente relatados acima os fatos principais que, segundo Lestringant, parecem ter contribuído para a formulação da crítica de Léry a seus conterrâneos. Tal crítica se fez a partir da reprovação desse costume entre os Tupinambá, mas tendo em vista o grau de civilização destes, qualquer fato que se assemelhasse a tal costume - caso de Villegagnon - ou a própria realização desse ato, entre os cristãos - caso de Sancerre - seria considerado bem pior do que a presença de tal prática entre os indígenas.

A relativização que Léry realiza da guerra indígena não se restringiu a uma postura crítica à Europa e às guerras religiosas que lá ocorriam. Ela surgiu também no elogio de Léry às habilidades indígenas em suas guerras - nas quais o nativo era

\footnotetext{
${ }^{135}$ LESTRINGANT, Frank. O canibal. Grandeza e decadência. Brasília: UnB, 1997. p.108-9.

${ }^{136}$ LÉRY, Jean de. Op. Cit. p.60.

${ }^{137}$ LESTRINGANT, Frank. O canibal. Grandeza e decadência. Brasília: UnB, 1997. p.112.

${ }^{138}$ Ibidem, p.114.
} 
comparado ao guerreiro europeu - e na louvação à coragem do guerreiro indígena. Além disso, Léry fala em seu texto, sobre a atração nele exercida pelos ritos de guerra tupinambá:

"Confessarei que nos limitamos a assistir ao combate da retaguarda, apreciando as peripécias da luta. Devo acrescentar que embora tenha visto muitas vezes regimentos de infantaria e cavalaria nos países europeus, com seus elmos dourados e suas armas reluzentes, nunca espetáculo de combate me deu tanto prazer aos olhos. Mas além da diversão de vê-los saltar, assobiar e manobrar com destreza para todos os lados, causava encanto o espetáculo de tantas flechas emplumadas de vermelho, azul, verde e outras cores, brilhando aos raios do sol; e não era menos agradável ver os adornos feitos dessas penas naturais com que se vestiam os selvagens". 139

Portanto, em Léry, o Tupinambá foi mais que um termo de comparação para as "selvagerias" praticadas por seus conterrâneos por conta das disputas religiosas que assistiu. Como nas outras crônicas desse período, o indígena, para ser compreensível para o público europeu precisou ser traduzido como o inverso desse europeu $^{140}$. O resultado disso foi uma leitura ambígua do sistema de vinganças tupi. Assim, se o ato mais condenado desse sistema - a antropofagia - foi relativizado e "desculpado" perante o canibalismo de Villegagnon e aquele da família de Sancerre, ele não deixou de ser condenado em seus motivos que se chocavam, como vimos através da fala de Villegagnon, com os princípios da doutrina cristã:

"Declarada a guerra entre quaisquer dessas nações, alegam todos que ressentindose o inimigo eternamente da injúria seria absurdo deixar o preso escapar; o ódio entre eles é tão inveterado que se conservam perpetuamente irreconciliáveis. Donde nos parece possível concluir que Maquiavel e seus discípulos, de que a França por infelicidade anda cheia nestes tempos não passam de imitadores desses bárbaros cruéis. Esses ateus ensinam, e praticam, contrariamente à doutrina cristã que os novos serviços nunca devem apagar as antigas injúrias. Os homens, insuflados pelo

\footnotetext{
${ }^{139}$ LÉRY, Jean de. Op. Cit., p.144.

${ }^{140}$ AGNOLIN, Adone. Op. Cit., p.71.
} 
diabo não podem perdoar-se uns aos outros e eles bem o demonstram, revelando terem o coração mais falso e feroz que os próprios tigres. "141

Temos, portanto, na formulação da concepção de Léry sobre a guerra tupi, a presença de dois termos de comparação: a doutrina cristã defendida por Léry e os desvios dessa doutrina realizados por aqueles que se diziam cristãos. Em relação à primeira, a guerra indígena será sempre condenada, em relação à segunda, ela será desculpada.

$\mathrm{Na}$ versão de Léry sobre a origem da guerra indígena, veremos que prevalecerá o código dado pela doutrina cristã, ao invés do olhar relativizado do transcritor da narrativa. Primeiramente porque essa narrativa, para ser compreensível para o público europeu precisava de uma referência à uma tradição conhecida; Léry escolheu as Santas Escrituras para compor as bases sobre as quais traduziria esse fragmento mítico.

Esta relação parece ressoar aquela feita pelos missionários jesuítas entre esses dois temas, da qual falamos anteriormente, ou seja, nesse capítulo Léry parece opor as reminiscências indígenas do cristianismo, enquanto um dos motivos de sua possível salvação, à prática da guerra, que figura em todos os relatos como a causa da perdição indígena. Nessa estrutura, entre uma e outra teríamos a inconstância indígena em seguir os ensinamentos cristãos como motivos de sua perdição.

A queixa a essa inconstância não se restringe ao episódio ao qual já nos referimos, em que os índios, depois de prometerem seguir à Deus, entoaram seus cânticos de guerra. Ela surge também quando Léry narra as tormentas infringidas por Ainhan aos indígenas. Estes últimos, admirando-se do fato dos franceses não serem também atormentados, questionam-os, como conta Léry:

"Admiravam-se muito quando lhes dizíamos que não éramos atormentados pelo espírito maligno e que isso devíamos ao Deus de quem tanto lhes falávamos, pois, sendo muito mais forte que Ainhan, lhe proibia fazer-nos mal. E acontecia que, sentindo-se amedrontados, prometiam crer em Deus. Mas passado o perigo zombavam do santo, como se diz no provérbio, e não se recordavam mais de suas promessas". ${ }^{142}$

\footnotetext{
${ }^{141}$ LÉRY, Jean de. Op. Cit. p.,138.

${ }^{142}$ LÉRY, Jean de. Op. Cit. p.159.
} 
Esse trecho em que Léry associa Anhã - ou o espírito que atormentava os índios - ao Diabo, mostra que ele também - como todos os outros cronistas concebeu o indígena como uma humanidade sob o domínio do Demônio. Isso demonstra que a terceira face da leitura européia do homem americano, a demonização, verificada por Laura de Mello e Souza ${ }^{143}$, também estava presente na tradução realizada por Léry do Tupinambá.

Essa demonização junto com a prática da guerra explicaram a inconstância indígena em obedecer ao "verdadeiro Deus" e, portanto, a exclusão do indígena do mundo cristão. Esses temas se difundem na versão de Léry sobre a origem da guerra entre os indígenas, a qual analisaremos a seguir.

$$
* * *
$$

Todos os fragmentos míticos dos Tupinambá presentes na obra de Léry foram comparados com o texto bíblico e transformados pela operação da escrita, como destaca Certeau:

"Esta articulação entre a palavra e a escrita é por sua vez encenada na Histoire. Focaliza, discretamente todo o relato, mas Léry explicita sua posição num episódio chave, no capítulo central no qual trata da religião, quer dizer, da relação que o cristianismo da escritura estabelece com as tradições orais do mundo selvagem." "144

Nesse capítulo estão todas as narrativas Tupinambá que Léry registrou: daquelas relativas à guerra, àquela que permitiu a inclusão do americano na história contada pela Bíblia sobre o dilúvio universal ocorrido nos tempos de Noé. Assim, Léry parece ser o primeiro autor a incluir a narrativa sobre a origem da guerra indígena no capítulo destinado a tratar da "religião" indígena, relacionando, dessa forma, esses dois temas.

Portanto, é na análise da religiosidade nativa - com referência ao texto bíblico que se desenvolve no referido capítulo - que encontramos as bases da leitura que Léry realizou da origem das guerras intertribais. Nela se imbricaram algumas características que fizeram do Tupinambá uma alteridade absoluta ou o oposto do

\footnotetext{
${ }^{143}$ SOUZA, Laura de Mello e. Op. Cit. p. 67

${ }^{144}$ CERTEAU, Michel de. A escrita da história. Rio de Janeiro: Forense Universitária, 2002. p.215.
} 
europeu: a antropofagia e a obediência ao Diabo. Estas se associaram dentro de uma narrativa que se relaciona ao texto bíblico sobre a pregação do Evangelho pelos apóstolos aos quatro cantos do mundo, já sugerida por Pompa ${ }^{145}$, e sobre a queda de Adão.

Segundo Lestringant, no relato do caso de antropofagia ocorrido em Sancerre, Léry associa o ato de antropofagia presenciado à narrativa bíblica sobre a queda de Adão:

"Fora uma velha, Philippes de la Feülle, que fizera cometer esse ato mais que bárbaro (...) Assim solicitado por essa nova Eva, o marido provou o fruto proibido. Por sua vez, ele vai tentar sua mulher até então ausente. Voltando das compras, a mulher descobre a macabra culinária e, apesar das reticências bem compreensíveis, termina por se juntar ao repasto. Para essa narrativa invertida da Queda, Léry empresta à narrativa bíblica do Gênese sua sintaxe e seu despojamento". ${ }^{146}$

Se mais tarde a antropofagia indígena foi desculpada mediante esse episódio, na estrutura da narrativa sobre a origem da guerra encontramos também a relação entre sua fundação e a queda do Tupinambá: o início da antropofagia entre os índios também se deve à desobediência deles ao Deus cristão, assim como Adão e Eva desobedeceram à Deus experimentando o fruto proibido.

Contudo, na narrativa indígena, esse fruto - representado pela carne do inimigo - não foi oferecido diretamente pelo segundo profeta: o que se ofereceu ao índio foi o tacape que era a arma utilizada na execução do inimigo. Dessa forma, o segundo profeta que surge na narrativa indígena é aquele que institui a prática da guerra.

No texto bíblico esse segundo profeta é o falso profeta, ou seja, o Diabo. Portanto, junto com o início da guerra iniciam-se também as tormentas indígenas causadas por Anhã e o predomínio do Diabo nessa quarta parte do mundo.

Portanto, a visão de Léry do sistema de vingança indígena parece incluir essa prática na história cristã a partir da explicação sobre a origem do domínio do Diabo no Novo Mundo, ou seja, se a mudança do Diabo para a América foi um tema comum na época de Léry, ele parece ter sido o primeiro a associar em uma narrativa

\footnotetext{
${ }^{145}$ POMPA, Cristina. Op. Cit. p.56.

${ }^{146}$ LESTRINGANT, Frank. O canibal. Grandeza e decadência. Brasília: UnB, 1997. p.112.
} 
etiológica alguns dos costumes indígenas mais condenados com o início do reinado do Diabo nessa região.

Outro elemento caracterizador da cultura indígena como cultura decaída segundo o relato de Léry é a oralidade. Assim, a comparação que ele realiza entre o texto bíblico e a narrativa indígena corresponde às relações entre escrita e oralidade, uma representando aquilo que é verdadeiro e a outra representando o falso. Aqui a referência ao texto bíblico serve não só para corrigir aquilo que a memória esqueceu, mas também para organizar e apoiar a fala do outro na própria tradição. Como demonstrou Certau, a narrativa de Léry se constitui a partir das quatro noções que organizam a ciência que no século XVII receberá o nome de etnologia:

“a oralidade (comunicação própria da sociedade selvagem ou primitiva), a espacialidade (ou quadro sincrônico de um sistema sem história), a alteridade (a diferença que apresenta um corte cultural), a inconsciência (estatuto de fenômenos coletivos referidos a uma significação que lhes é estranha e que não é dada senão a um saber vindo de algures) . Cada uma delas garante e chama as outras (...) Corresponde à etnologia articular estas leis numa escrita e organizar este espaço do outro num quadro de oralidade". ${ }^{147}$

Percebe-se aqui a importância da palavra escrita nesse período. Como destacou Certeau, a partir da crise instaurada no século XVI, ela assumiu uma nova função se transformando no "instrumento de um duplo trabalho que se refere, por um lado com o homem 'selvagem'; por outro a relação com a tradição religiosa". ${ }^{148}$ Assim, para Léry, todos os elementos da narrativa mítica "selvagem" que não podem ser reduzidos ao código religioso presente na Bíblia constituem a fábula.

Constatadas, por fim, algumas noções que organizaram o registro de Léry da narrativa sobre a origem da guerra, passamos à avaliação dos elementos da simbologia indígena que possivelmente estão presentes no registro desse código.

${ }^{147}$ CERTEAU, Michel de. Op. Cit. p. 211.

${ }^{148}$ Ibidem, p.213. 


\section{A origem da guerra, segundo os Tupinambá}

Como vimos por meio da análise precedente, o registro de Léry da narrativa sobre a origem da guerra entre os Tupinambá contém alguns elementos do cristianismo que se relacionam tanto com a visão desse autor sobre o sistema de vinganças tupi, quanto com sua crítica a seus conterrâneos, em guerra religiosa desde sua passagem pelo Brasil: ambos os eventos assistidos por Léry foram relacionados com a "queda" dos grupos sociais neles implicados, a partir de sua desobediência a Deus e, portanto, da sua submissão ao Diabo.

Entretanto, a presença desses elementos cristãos na narrativa pode ser também interpretada como uma releitura realizada pelos Tupinambá das novidades com as quais eles tiveram contato a partir da chegada dos europeus ao Brasil: o estrangeiro, seu sistema de crenças, seus artefatos culturais e sua visão da cultura nativa.

Como apontou Pompa, no início da Idade Moderna o código religioso cristão constituiu uma linguagem privilegiada tanto para a tradução do outro para o público europeu, quanto para a mediação da comunicação entre europeus e indígenas ${ }^{149}$. Esta última se construiu também a partir da:

“utilização de elementos da cultura nativa como linguagem para veicular conteúdos da fé católica, na mesma linha da utilização do nome Tupã para indicar Deus, Jeropari ou Anhã para o Demônio e assim por diante”. 150

Assim, como veremos com mais detalhes posteriormente, o primeiro profeta que tenta convencer os indígenas a obedecerem ao Deus cristão pode ser associado ao missionário ou ao estrangeiro (não só pela sua ação, mas também pelo próprio termo usado para designá-lo: mair); a concepção da guerra como maldição parece demonstrar que os nativos conheciam a visão de alguns europeus sobre seus ritos de guerra; e, como vimos, essa narrativa mescla em sua estrutura a profecia cristã sobre a pregação apostólica por todo o mundo com a narrativa sobre a queda de Adão.

Veremos posteriormente que a presença da estrutura das referidas passagens das Sagradas Escrituras podem ter sido uma tradução indígena dessas narrativas, a

\footnotetext{
${ }^{149}$ POMPA, Cristina. Op. Cit. p.48-9

${ }^{150}$ Ibidem, p.53.
} 
despeito do fato dos franceses, no período em que estiveram no Brasil, não terem realizado a catequese dos indígenas brasileiros.

Portanto, as representações nativas sobre as guerras inter-tribais só podem ser aqui apreendidas a partir da noção de que estamos mediante um jogo de espelhos, como sugeriu Pompa ${ }^{151}$, em que entre o registro escrito e a palavra dita, temos as "mitologias" cristã e tupinambá embasando a leitura realizada sobre a alteridade. Acreditamos que os elementos cristãos presentes nesse fragmento mítico são oriundos não só da operação realizada por Léry de correção da "fábula" indígena, que organizou-a em relação à "inconsciência" indígena da história universal relatada pela Bíblia, mas também de uma tradução realizada pelo nativo dos elementos cristãos com os quais teve contato.

Se essa tradução, como apontamos anteriormente, possivelmente não se fez a partir das palavras dos missionários jesuítas, já que, não há registro de missões entre os Tupinambá anterior à instalação dos franceses na Baía de Guanabara, ela parece ter sido efetuada a partir do código cristão dos franceses e dos portugueses com os quais os indígenas tiveram contato. Como vimos anteriormente, a condenação desse hábito, não se restringiu à palavra dos missionários, sendo unânime dentre quase todos os europeus que escreveram sobre a guerra indígena nos primeiros anos da colonização portuguesa da América.

\section{$* * *$}

A possível inserção dos elementos supracitados parece representar uma refundação do mito relativo ao sistema de vinganças indígena a partir das mudanças ocorridas no ritual guerreiro. Essa re-fundação, portanto, constituiu-se como uma reelaboração da simbologia indígena sobre a guerra a partir das novidades apresentadas pelo contato, que forneceu elementos, não previstos pela cultura indígena, para que os nativos repensassem tanto a própria concepção de mundo quanto o lugar por eles ocupado nesse mundo.

Em relação aos ritos da guerra e da antropofagia, como vimos há pouco, algumas novidades foram introduzidas a partir do encontro e, no caso específico da França Antártica, segundo o relato de Léry, essa intervenção se fez através da

${ }^{151}$ POMPA, Cristina. Op, Cit. p.56. 
participação na guerra e no ritual antropofágico de alguns intérpretes ${ }^{152}$, do uso da guerra nativa como forma de obtenção de escravos, por Villegagnon ${ }^{153}$, e da condenação verbal dessa guerra e do ritual antropofágico ${ }^{154}$.

Acreditamos que essas interferências nos rituais da guerra e da antropofagia possam ter colocado questões para os Tupinambá repensarem esses elementos da própria cultura. Essa reflexão crítica sobre os fundamentos da guerra, parece ser um modo de historicidade dessa cultura. Portanto, na análise que pretendemos realizar, é necessário refletir sobre a forma como a história - trazida de fora pelo confronto com o outro - operou nessa sociedade.

Como apontamos no primeiro capítulo, optamos pela perspectiva teórica oferecida por De Martino nas obras Fuore, símbolo, valore ${ }^{155}$ (1980) e Il mondo magico: prolegomeni a una storia del magi€smo ${ }^{156}$ (1948) para analisarmos a questão do modo como a história opera nas sociedades extra-ocidentais, já que tal abordagem parece ser a mais apropriada para o problema que propomos nesse trabalho, a saber, a questão de uma possível re-fundação da origem da guerra pelos Tupinambá, a partir dos novos elementos com os quais estes últimos vinham tendo contato desde o seu encontro com a alteridade européia.

Retomemos a abordagem de De Martino: segundo o autor, nas sociedades tradicionais, a presença atuante do homem no mundo constitui uma realidade a ser construída. Nesse sentido, a simbologia mítico-ritual possui o importante papel de fundar a presença humana e de protegê-la contra a ameaça de "não ser mais no mundo". Tal ameaça se apresentaria à sociedade através dos acontecimentos não previstos e, por isso, geradores de uma crise a ser resolvida socialmente através do ritual que re-atualizaria os tempos míticos da fundação do mundo.

Durante a resolução da crise, o devir seria de-historificado, e se instauraria assim um regime protegido. Contudo, em De Martino, isso não representaria a negação da história (com o sentido de curso dos acontecimentos), e sim a forma do

\footnotetext{
${ }^{152}$ LÉRY, Jean de. Op. Cit., p.153.

${ }^{153}$ LÉRY, Jean de. Op. Cit., p.145.

154 Ibidem, p. 168.

${ }^{155}$ DE MARTINO, Ernesto. Fuore, simbolo, valore. Milão: Fetrinelli, 1980. apud: AGNOLIN, Adone. Op. Cit.

${ }^{156}$ DE MARTINO, Ernesto. Il mondo magico: prolegomeni a una storia del magismo. Torino: Eniaudi, 1948. apud: POMPA, Cristina. Memórias do fim do mundo: Para uma leitura do movimento sócioreigioso de Pau de Colher. Dissertação de Mestrado. Campinas, Unicamp, 1995.
} 
homem recuperar o tempo e sua realidade profana, na resolução da crise instaurada pelo não previsto ${ }^{157}$.

Dessa forma, segundo a perspectiva oferecida por De Martino, a crise instaurada pela presença de elementos não previstos miticamente - representados pela presença européia e sua forma peculiar de relação com os Tupinambá - seria resolvida através do acionamento dos mecanismos mítico-rituais que re-fundariam as bases dos elementos culturais questionados a partir do confronto com a alteridade.

Um estudo da relação entre a historicidade européia e aquela das sociedades não-ocidentais, na produção de uma re-fundação do mito e do rito dessas últimas, assim como na determinação de um rumo não esperado para a ação das primeiras, é realizado por Marshall Sahlins na obra Ilhas de História ${ }^{158}$, que trata especificamente da interpretação que os maori e os ingleses fizeram da cultura do outro, fato que tornou possível a criação conjunta de um novo mito a partir de novos ritos ${ }^{159}$.

No fim do século XVIII, no contexto das descobertas inglesas das ilhas da Oceania, o capitão James Cook, com seus navios, desembarcou na ilha Kava'i. Apesar de sua vasta experiência de contato com os polinésios, ele se deparou com um fato singular: milhares de nativos esperavam-no nas praias da ilha, embarcações com comida chegavam aos navios e havia ansiedade entre as mulheres para "se ligarem" amorosamente a Cook e a seu pessoal. Além disso, ouvia-se os polinésios gritarem: 'Ó Lono': eles saudavam o deus da fertilidade, que eles aguardavam e para quem essa recepção fora preparada. ${ }^{160}$ Coincidindo com a data das celebrações rituais ao deus havaiano, a chegada de James Cook ao Havaí foi interpretada como o retorno de Lono (conforme previsto no mito e celebrado pelo rito).

Segundo o mito, Lono era um deus que a cada ano novo vinha disputar com o rei a fertilidade da natureza que propiciava a vida humana na terra. Dessa forma, a chegada de Cook ao Havaí foi, para os havaianos a atualização desse mito. Além disso, conforme, Sahlins pode perceber a partir da análise dos documentos relativos a esse fato, o capitão James Cook, apesar de desconhecer o mito, teve um

\footnotetext{
${ }^{157}$ POMPA, Cristina. Memórias do fim do mundo: Para uma leitura do movimento sócio-reigioso de Pau de Colher. Dissertação de Mestrado. Campinas, Unicamp, 1995. p.54-5

${ }^{158}$ SAHLINS, Marshall. Ilhas de História. Rio de Janeiro: Jorge Zahar ed., 1990.

${ }^{159}$ Temos em vista que se trata de uma sugestão complexa e no que diz respeito ao nosso trabalho, o repertório é fundamentalmente minimalista, na medida em que o trabalho de Sahlins trata de um repertório totalitário. Portanto, para ele, a oposição entre estrutura e ação é um problema efetivo, ao passo que nós não trabalhamos com a "totalidade social", como propõe a abordagem antropológica de Sahlins.

${ }^{160}$ SAHLINS, Marshall. Op. Cit., p. 140-1.
} 
comportamento que permitiu sua associação a Lono, contribuindo assim para a ritualização do referido mito.

Segundo Sahlins, há duas perspectivas envolvidas nesse fato e que, por isso, devem ser consideradas na análise se quisermos compreender a trama que evolveu o assassinato de Cook: a cultural, em que a estrutura assimila o evento, e a histórica, em que a estrutura é modificada pelo evento. Para os havaianos, Cook era Lono, fato comprovado por sua participação ritual no mito e pela contingência histórica de sua chegada ao Havaí. Assim, o evento da chegada dos ingleses à ilha Kava'i foi assimilado à estrutura da cultura havaiana a partir da sua inclusão em uma realidade mítica.

Contudo, Cook ao não compartilhar desse código cultural - não conhecendo, portanto, o mito - produziu fatores novos não assimiláveis à estrutura do mito: retornou a ilha e seqüestrou o rei maori, desafiando, assim, a ordem fundada pelo mito. Esses dois últimos fatos, não assimiláveis como eventos à estrutura mítica, foram resolvidos ritualmente pelo assassinato de Lono. Assim, a estrutura dada pelo mito foi modificada pelos eventos produzidos pela participação dos ingleses - uma cultura histórica - na re-atualização do mito. Contudo, as soluções buscadas para a resolução do impasse foram dadas ritualmente com base na narrativa mítica. Temos assim, por meio desse tipo de interpretação, um viés analítico em que mito, rito e história se articulam tanto na realização do evento, quanto na análise posterior elaborada para a compreensão desse evento.

É importante destacar que, nessa análise o autor não abandona a perspectiva estruturalista, no entanto ele critica a concepção de estrutura dada por Saussure e adotada por Lévi-Strauss, a saber, "um conjunto estático de oposições e

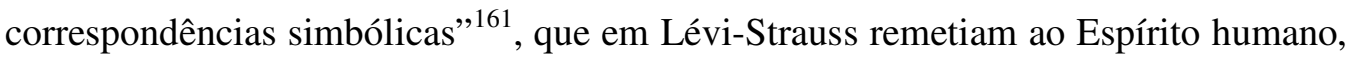
ao propor que:

"a estrutura é processual, um desenvolvimento dinâmico das categorias e de suas relações, resultando em um sistema mundial de geração e de regeneração. Enquanto programa do processo de vida cultural, o sistema tem uma diacronia interna, que é, por si mesma temporal e mutante. A estrutura é a vida cultural das formas elementares. Exatamente porque essa diacronia é estrutural e repetitiva é possível

${ }^{161}$ SAHLINS, Marshall. Op. Cit. p. 109. 
seu diálogo com o tempo histórico enquanto projeto cosmológico que abarca o evento contingente". ${ }^{162}$

A idéia de estrutura proposta pelo autor decorre de um tipo de análise preocupada não só com o contexto cultural onde ocorre o evento - que fornece as categorias a serem reavaliadas na ação - como também com o contexto histórico, ou seja, o autor afirma que os esquemas culturais são repensados (historicamente) na ação. ${ }^{163}$ Todavia, isso não quer dizer que as culturas são estruturalmente homólogas, pois existem diferenças estruturais na forma de se viver a diacronia. Esta diferença dividiria as sociedades entre culturas com estruturas performativas e com estruturas prescritivas:

“as estruturas performativas e as prescritivas teriam historicidades diversas. Poderíamos falar que elas estão diferencialmente abertas para a história. As ordens performativas tendem a assimilar-se às circunstâncias contingentes, enquanto as prescritivas tendem a assimilar as circunstâncias à elas mesmas, por um tipo de negação de seu caráter contingente e eventual". ${ }^{164}$

Entretanto, o autor ressalta que estes são tipos ideais de estrutura, podendo-se encontrar os dois tipos numa mesma sociedade. ${ }^{165}$ É a partir dessa concepção não dicotomizante das estruturas em relação à história que o autor desenvolve a noção de estrutura da conjuntura que seria "a realização prática das categorias culturais em um contexto histórico"166

Dessa forma, podemos dizer que, nesse tipo de análise as relações entre mito, rito e história decorrem da cultura e do contexto histórico em análise, ou que "as diferentes ordens culturais têm seus modelos próprios de ação, consciência e determinação histórica - as suas próprias práticas históricas". ${ }^{167}$ Essa é a idéia de Vernant, presente em seus estudos sobre a alteridade histórica - a Antigüidade grega - que como Sahlins destaca, compõe a base de seu ensaio sobre uma alteridade cultural, aquela dos maori.

\footnotetext{
${ }^{162}$ Ibidem, p. 110.

${ }^{163}$ SAHLINS, Marshall. Op. Cit., p. 7.

${ }^{164}$ Ibidem, p. 13.

165 Ibidem, p. 14.

${ }^{166}$ Ibidem, p. 15.

${ }^{167}$ Ibidem, p. 17.
} 
Portanto, segundo a proposta de De Martino e de Sahlins, as sociedades extraocidentais vivem a história de forma distinta daquela das sociedades ocidentais. Segundo ambos os estudos, essas sociedades são abertas de forma distinta para os novos eventos. Nessa abertura há a alteração do mito e do rito, para re-significarem a realidade modificada pela contingência histórica.

As orientações dadas pelos estudos de ambos os autores esclarecem a forma como a história opera entre as sociedades que não desenvolveram a mesma concepção de história do ocidente, reforçando assim a nossa hipótese de que a narrativa registrada por Léry possa ser analisada também em termos de uma releitura nativa dos eventos gerados desde os primeiros contatos com os europeus com relação à instalação dos franceses na Baía de Guanabara.

O primeiro evento apresentado por essa narrativa, é a chegada de um estrangeiro ao "país" dos Tupinambá:

"há muito tempo, não sei mais quantas luas, um mair como vós, e como vós vestido e barbudo, veio a este país(...)"

Esse início parece ser uma assimilação do encontro com os europeus na estrutura do mito. O mair que surge aqui talvez possa, sem maiores problemas, ser associado ao francês, já que essa designação, segundo os relatos de Léry e de Thevet, era a forma pela qual os franceses eram chamados pelos Tupinambá na época da colonização francesa do Rio de Janeiro. Thevet, em seu relato, nos fornece o histórico das designações recebidas pelos europeus desde o primeiro contato com os indígenas:

"Logo que esta terra foi descoberta (...), estes selvagens, admirados de ver os cristãos que thes pareceram estranhíssimos tanto na aparência quanto no procedimento, acreditaram que os mesmos fossem profetas, passando a reverenciálos como deuses. Mas quando a canalha viu que os cristãos adoeciam, morriam e

${ }^{168}$ LÉRY, Jean de. Op. Cit. p.168. 
estavam sujeitos às suas mesmas paixões, começou a desprezá-los e maltratá-los sistematicamente (...)

Os índios, além disso, deixaram de chamar o branco de caraíba, que significa 'profeta' ou 'semi-deus', preferindo chamar-nos desdenhosamente e infamemente, de mair, nome de um de seus antigos profetas que eles detestam e tratam com desprezo".

Nesse trecho, as designações dadas pelos Tupinambá aos europeus parecem refletir a forma como os primeiros foram construindo a imagem do outro depois da descoberta: primeiramente, o europeu foi concebido e denominado como um ser dotado de poderes sobrenaturais. Algum tempo depois, iniciou-se um questionamento da associação entre o estrangeiro e o herói mítico, mudando-se, portanto, sua designação.

Gilberto Mazzoleni, em sua obra $O$ planeta cultural analisa o problema colocado pelo encontro do Ocidente com as culturas extra-européias a partir da questão: "Como reagiram, por seu lado, as culturas extra-européias ao impacto com o Ocidente?"169

Segundo esse estudo, os relatos sobre os primeiros contatos entre os europeus e as outras culturas apontam para o fato de que, na maior parte dos casos, os europeus foram considerados divindades que retornaram ao mundo humano, ou seja, eles foram assimilados aos mitos das culturas extra-européias. Por outro lado, uma outra forma de se conceber o diverso foi se delineando entre as culturas extraeuropéias: constatada a insuficiência dos instrumentos tradicionais para responder às ofensivas externas e comprovada a humanidade dos europeus, - estes perderam seu lugar de sujeitos míticos - essas sociedades realizaram uma revisão de seu patrimônio cultural criando novos mitos para explicar a diversidade física e cultural entre brancos, negros e índios.

Assim, reconstruiu-se a própria cultura a partir dos novos acontecimentos, com o intuito de elaborar "uma nova síntese entre realidade imutável [dada pelo mito] e realidade passível de intervenção [ritual]". ${ }^{170}$ No caso analisado, as novas sínteses foram sendo elaboradas para a construção de novas identidades, a partir da elaboração da identidade do outro.

\footnotetext{
${ }^{169}$ MAZZOLENI, Gilberto. Op. Cit. p. 107.

${ }^{170}$ MAZZOLENI, Gilberto. Op. Cit., p. 112-3.
} 
Portanto, o estudo de Mazzoleni parece reiterar a informação de Thevet, segundo a qual, o modo de se conceber o estrangeiro mudou ao longo do período de contato entre europeus e indígenas. Entretanto, não nos parece, quando confrontamos o texto da segunda obra de Thevet - Cosmographie universelle - , que no contexto da França Antártica o francês tenha perdido sua característica de sujeito mítico, conforme veremos a seguir.

Interessa então procurar decodificar o sentido do termo mair na época em que o registro foi realizado, com ênfase no sentido assumido por esse termo na narrativa registrada por Léry. Para isso, escolhemos retomar alguns registros realizados por Thevet em que consta esse termo, presentes nas Singularidades da França Antártica $^{171}$ e na Cosmographie Universelle ${ }^{172}$.

Como apontam os estudos de Alfred Métraux ${ }^{173}$ e de Frank Lestringant ${ }^{174}$, Thevet foi o grande compilador da mitologia Tupinambá: seu registro, apesar de não estar isento de comparações e assimilações que se desprendem das suas concepções de religião e de civilização, foi o menos influenciado pelas aproximações com o relato bíblico, em relação aos registros realizados pelos outros cronistas. Por isso, sua obra nos fornece material para tentarmos compreender a simbologia nativa contida no fragmento mítico analisado.

Além disso, Thevet esteve na França Antártica quase no mesmo período em que lá esteve Léry, convivendo com o mesmo grupo de nativos. Dessa forma, acreditamos que uma breve análise dos textos desse autor em que constam o termo maire, nos auxiliará a encontrar a visão nativa na versão mítica registrada por Léry sobre a origem da guerra.

O primeiro registro de Thevet em que consta o termo maire é aquele que citamos acima, em que o autor fornecia um breve histórico das concepções nativas sobre o europeu. Segundo esse registro, mair seria uma forma desdenhosa e infame do Tupinambá chamar o europeu, pois esse seria o nome que eles davam a "um de

${ }^{171}$ THEVET, André. As singularidades da França Antártica. Belo Horizonte: Itatiaia; São Paulo: Edusp, 1978.

${ }_{172}$ THEVET, André. La Cosmographie Universelle. Paris, 1575.

${ }^{173}$ MÉTRAUX, Alfred. A religião dos tupinambás e suas relaçães com a das demais tribos tupiguaranis. São Paulo: Ed. Nacional/ Edusp, 1979.

${ }^{174}$ LESTRINGANT, Frank. Mitológicas: a invenção do Brasil. Revista USP. São Paulo, n., 
seus antigos profetas que eles detestam e tratam com desprezo" ${ }^{\text {175 }}$. Dessa forma, respeitando-se a coerência interna dessa obra, os heróis dos mitos nela narrados não são nomeados como Maire, mas como o Grande Caraíba.

No entanto, vinte anos depois da sua primeira publicação sobre o Brasil, na obra Cosmographie Universelle (1575), Thevet retoma o termo Maire e o explica novamente, durante seu relato dos mitos tupinambá. Esse termo surge durante as transcrições da mitologia nativa, pois ele compõe o nome de quase todos os heróis que aparecem nessa mitologia. A primeira e a segunda definição que Thevet oferece dessa palavra estão nos mitos em que Maire-Monan, aparece como o personagem principal, segundo esses registros Maire-Monan significa:

"ce mot Maire, en langue sauvage, signifie autant que transformateur: d'autant que cestuy cy estoit fort adextre à transformer aucunes choses en d'autres, et Monan signifie autant que vieil et ancien". ${ }^{176}$

Mais adiante, Thevet explica a crença tupinambá de que os franceses fossem os descendentes de Maire-Monan:

"Et a este ce mot Maire, usurpé jusques à leur deluge, qu'ils disent avoir esté universel, sur ceux qui estoient rares em ouvres: de sorte que encor voyans que nous sçavons faire plus de choses q'eux, et que nos exercices leur apparoisent admirables, ils dissent que nous sommes les successeurs et vrays enfans de Maire Monan et que sa vraye race c'est tournée en noz terres, lá ou ils en sont privez, à cause du deluge (...) $)^{\prime 177}$

No relato sobre Maire-Pochy, Thevet acrescenta que Maire era o termo usado, para designar "todos os Caraíbas, autores das grandes maravilhas"178. Portanto, os dois termos que, como vimos, eram distintos na primeira obra de Thevet sobre o Brasil, aparecem, segundo as passagens que acabamos de citar da Cosmographie, como sinônimos.

175 THEVET, André. As singularidades da França Antártica. Belo Horizonte: Itatiaia; São Paulo: Edusp, 1978. p.100.

176 THEVET, André. La Cosmographie Universelle. Paris, 1575. apud MÉTRAUX, Alfred. A religião dos Tupinambá e suas relações com a das demais tribos tupi-guaranis. São Paulo: Editora Nacional: Edusp, 1979. p.199.

177 THEVET, André. Op. Cit., p.199.

${ }^{178}$ Ibidem, p. 205. 
São três os heróis que possuem o termo Maire na composição de seus nomes: Maire-Monan, Maire-Atá e Maire-Pochy. Como veremos a seguir, a ação transformadora está presente em todas as narrativas em que esses heróis aparecem. Assim, o termo mair, parece possuir dois sentidos: estrangeiro (ou europeu) e transformador. Para tentar descobrir o sentido desse termo na narrativa registrada por Léry acreditamos ser necessário retomar as narrativas tupinambá em que esses personagens aparecem, enfatizando o tipo de transformações que eles operam.

O primeiro Maire que surge nos registros míticos da Cosmographie de Thevet é Maire-Monan. Os relatos sobre esse herói registrados nessa obra parecem constituir ora uma continuidade, ora uma variação daqueles registrados nas Singularidades: ele era um dos descendentes de Irin-Magé que teria aparecido entre os índios depois do grande dilúvio de fogo e de água causado pelo "profeta" que o precedeu, Monan, do qual era parente ${ }^{179}$, e antes do segundo dilúvio de água provocado pela briga dos irmãos Tamendoré e Ariconte, filhos de Sumé ${ }^{180}$. Este segundo dilúvio é mencionado de forma sucinta nas Singularidades. Ele aparece também em uma outra versão mítica sobre a origem da jetica, presente na Cosmographie.

Segundo o registro das Singularidades, a jetica foi trazida por um Grande Caraíba, na época em que os indígenas se alimentavam "de ervas e raízes como os animais". Ele ensinou a uma jovem como plantá-la, e desde então esse conhecimento foi sendo transmitido de geração à geração. O Deus cristão, segundo Thevet, era confundido pelos nativos com esse Caraíba, por conta de suas criações:

"Quando lhes falamos a respeito de Deus, como algumas vezes o fiz, eles nos escutam atentos e maravilhados, perguntando eventualmente se não seria este Deus o mesmo profeta, que lhes ensinou a plantar os tubérculos que chamam de jetica" ${ }^{181}$.

Já na Cosmographie, Thevet conta que nos primórdios dos tempos houve uma grande fome da qual muitos índios estavam morrendo. Dentre os índios havia uma mulher que mandava seus filhos ao campo para procurar alimentos. Certa vez, chegando ao campo, essas crianças encontraram uma outra criança que elas acreditaram que também estava lá procurando alimentos, por isso, elas começaram a

\footnotetext{
${ }^{179}$ Ibidem, p. 198.

${ }^{180}$ Ibidem, p. 200.

181 THEVET, André. As singularidades da França Antártica. Belo Horizonte: Itatiaia; São Paulo: Edusp, 1978. p.99
} 
insultar e a bater nessa criança, que na realidade era Maire-Monan que surgira entre os índios metamorfoseado em uma criança em quem bastava bater para fazer chover e crescer a jetica. A mãe das crianças, curiosa para saber de onde seus filhos estavam trazendo tantos víveres, resolveu seguí-los e descobriu o segredo de Maire-Monan. Quando seus filhos foram embora, ela recolheu os restos das raízes e as plantou. Desde então, os índios nunca mais passaram fome. ${ }^{182}$

Ambas as versões sobre a origem da jetica tratam da origem da agricultura por intermédio de um Caraíba que vem de longe para mostrar aos indígenas como cultivar essa raíz.

Mais adiante na Cosmographie, Thevet enumera as práticas culturais instituídas pelo Grande Caraíba e Maire, dentre elas está a agricultura. Como vimos há pouco, segundo a Cosmographie, Maire era uma designação usada para nomear os grandes Caraíbas ${ }^{183}$. Além disso, segundo essa obra, Maire-Monan foi um personagem mítico que instituiu várias práticas culturais que nas Singularidades foram atribuídas ao grande Caraíba. Por isso, é provável que esteja certa a hipótese de Métraux segundo a qual o grande Caraíba e Maire-Monan seriam o mesmo herói.

A partir dessa hipótese, Maire-Monan seria também o instituidor de várias práticas culturais entre os indígenas: em relação à alimentação, ele teria aconselhado os indígenas a comerem as carnes dos animais ligeiros e desaconselhado a ingestão da carne dos animais lentos. Além disso, ele teria ensinado os indígenas costumes que determinaram suas características físicas como o nariz achatado, a depilação e o corte de cabelo. Por fim, ele teria determinado a organização social indígena. Além de organizar:

“de acordo com o seu bel prazer, a todas as coisas, afeiçoando-as de vários modos e, em seguida, convertendo-as em diversas figuras e formas de animais, de pássaros e peixes, de conformidade com as regiões; até mudando o homem em animal para puni-lo, como bem lhe parecia, por sua maldade". ${ }^{184}$

\footnotetext{
${ }^{182}$ THEVET, André. La Cosmographie Universelle. Paris, 1575. apud MÉTRAUX, Alfred. A religião dos Tupinambá e suas relações com a das demais tribos tupi-guaranis. São Paulo: Editora Nacional: Edusp, 1979. p.203.

183 Ibidem, p. 199

${ }^{184}$ THEVET, André. Op. Cit., p.199.
} 
Essas metamorfoses, realizadas por Maire-Monan, segundo os relatos de suas aventuras, teriam causado a ira dos índios contra esse herói, que acabou resultando em seu assassinato:

“A gente cuja cólera ele despertara por causa de suas metamorfoses, decidira darlhe fim. Foi Maire Monan, então convidado a uma festa e obrigado a saltar sobre três fogueiras. Após ter sido bem sucedida na primeira prova, aquela divindade evaporou-se ao saltar a segunda fogueira e foi, assim, consumida pelas chamas. Sua cabeça, explodindo produziu o trovão, enquanto as labaredas do fogaréu se transformavam em raio. Imediatamente depois, Maire Monan subiu ao céu e virou estrela, juntamente com dois de seus companheiros". ${ }^{185}$

Portanto, segundo esses registros míticos, Maire-Monan era o fundador de várias práticas culturais dentre os homens que, abusando de seu poder de transformar homens em animais e, portanto, cultura em natureza, causara a ira dos índios e fora banido do mundo dos homens por intermédio do fogo.

Também recebe a designação Maire um outro herói indígena que também possuía a capacidade de transformar homens em animais. Segue abaixo a versão de Levi-Strauss sobre as aventuras desse herói:

"Na aldeia vivia um certo Maíra-Pochy, 'familiar do grande Monan', embora tivesse o status de servo ou até de escravo. Era feio e deformado, mas possuía poderes mágicos. Certo dia ele trazia um peixe e a filha de seu senhor quis experimentá-lo; imediatamente ela se sentiu grávida e deu à luz um belo menino. Todos os homens da aldeia foram reunidos, para saber de quem o menino aceitaria o arco e as flechas, indicando-o assim como pai: foi Maíra-Pochy. 'Resmungaram contra ele' e o abandonaram com mulher e filho. Mas 'o lugar onde vivia esse Maíra era abundante em todas as coisas, e o lugar em que os outros viviam era estéril e sem nenhum fruto, tanto que os infelizes morriam de fome'.

Apiedado, Maíra enviou-lhes provisões por intermédio da mulher e os convidou a vir visitá-lo. As roças férteis de seu anfitrião encheram-nos de cobiça e eles resolveram pilhá-las. Maíra transformou-os imediatamente em diversos animais. Esse incidente desgostou-o definitivamente da família da mulher e até da própria

${ }^{185}$ MÉTRAUX, Alfred. Op. Cit., p.4. 
mulher. 'Ele descobriu sua sórdida e feia face, tornando-se o mais belo dos humanos, e foi-se embora para o céu para lá viver à vontade'.,"186

Nessa narrativa, o status do Maire de escravo ou servo parece denunciar o fato de que ele não pertencia ao grupo com o qual ele convivia. Portanto, nesse mito Maire pode ser associado ao estrangeiro. O poder da transformação, como apontamos acima, também fazia parte de suas características: Maire-Pochy, desgostoso com o fato dos parentes de sua mulher terem pilhado suas roças, transforma-os em porcos e pássaros ${ }^{187}$, além de se transformar em sol, quando foge para o céu. Aqui a transformação dos homens em animais tem o caráter de punir os homens que infringiram o código cultural e a transformação do herói em sol se realiza a partir de seu descontentamento com os humanos. Portanto, a causa das transformações nesse mito parece se inverter em relação ao motivo do mito anterior sobre a morte de Maire-Monan.

A narrativa mítica sobre Maire-Pochy continua com a história de seu filho que resolve seguí-lo, indo para o céu:

"O filho de Maíra-Pochy, também chamado Maíra e que era um grande feiticeiro como o pai, quis ir junto com ele para o céu. Transformou-se durante algum tempo num rochedo que separava o mar e a terra, para impedir que o seguissem. Depois ele readquiriu a forma humana e permaneceu entre os índios. Entre outras maravilhas, ele fabricou uma diadema de chamas, que um companheiro apressado arrancou de suas mãos para experimentar: o imprudente pegou fogo, jogou-se na água e se transformou em saracura. Finalmente esse Maíra foi ao encontro do pai [o sol, segundo Thevet]". ${ }^{188}$

Aqui novamente o Maire é um "feiticeiro", com o poder de se transformar em outros seres e de transformar homens em animais. Aqui a metamorfose de homens em animais é realizada por intermédio do fogo para punir o humano que quis ultrapassar os limites que separam os homens dos seres sobrenaturais.

\footnotetext{
${ }^{186}$ LEVI-STRAUSS, Claude. Histórias de Lince. São Paulo: Companhia das Letras, 1993. p.51.

187 THEVET, André. La Cosmographie Universelle. Paris, 1575. apud MÉTRAUX, Alfred. A religião dos Tupinambá e suas relações com a das demais tribos tupi-guaranis. São Paulo: Editora Nacional: Edusp, 1979. p.204.

${ }^{188}$ LEVI-STRAUSS. Op. Cit. p.51-2.
} 
O último Maire que surge nas narrativas registradas por Thevet é Maire-Ata, neto de Maire-Pochy. Na narrativa em que aparece, ele é um personagem secundário, pai de um dos gêmeos cujas aventuras são narradas. Nesse mito, o papel desse herói é impor provas aos gêmeos para poder reconhecê-los como filhos. Aquele que é seu filho sempre sobrevive às provas impostas e salva seu irmão. ${ }^{189}$

Em relação à caracterização dos Maire nos mitos anteriores, menciona-se nessa narrativa que ele também era mago e advinho. Entretanto, as ações transformadoras nesse mito são realizadas por seu filho: ele ressuscita seu irmão toda vez que este morre durante as provas impostas por seu pai e, quando vinga a morte de sua mãe, juntamente com seu irmão, transforma o grupo que a matou e comeu em animais.

Nas narrativas acima transcritas, Maire-Monan, Maire-Pochy, o fogo e a água possuem o papel de transformadores. As transformações realizadas por esses heróis e por esses elementos operam nos limites entre natureza e cultura. $\mathrm{O}$ sentido dessas transformações muda conforme o contexto da narrativa ora a cultura torna-se natureza, ora a natureza torna-se cultura. Contudo, a mudança de sentido dessas metamorfoses não nos parece ser aleatória: nelas aquilo que possivelmente está sendo reafirmado é o código cultural do grupo, já que as transformações efetuadas nessas narrativas, sobretudo aquelas em que os homens são transformados em animais, parecem ser uma punição àquele que desrespeitou as prescrições tribais.

Maire-Monan, instituidor da maior parte das práticas culturais entre os homens é assassinado por abusar das transformações dos homens em animais, já que ele as realizava conforme sua vontade, e não como uma forma de punição aos homens cujo comportamento fugia às prescrições sociais. Nesse mito é o fogo que o retira da convivência com os humanos, transformando-o em estrela.

No caso das narrativas sobre Maire-Pochy, os homens são transformados em animais pelo Maire porque desrespeitaram o código social. Primeiramente, os parentes de sua mulher, ao expulsarem o herói com esta última e seu filho, romperam

\footnotetext{
${ }^{189}$ MÉTRAUX, Alfred. Op. Cit. p.21-9. Ver também: THEVET, André. La Cosmographie Universelle. Paris, 1575. apud MÉTRAUX, Alfred. A religião dos Tupinambá e suas relações com a das demais tribos tupi-guaranis. São Paulo: Editora Nacional: Edusp, 1979. p.200.
} 
as prescrições tribais, segundo a qual o marido, que fosse de fora do grupo familiar ou fosse prisioneiro (tendo, por isso, uma condição social que poderia ser interpretada por um europeu como a de um servo), deveria residir com a família da mulher, tornando-se "uma das principais unidades econômica do grupo da esposa"190. A seguir, o marido expulso é pilhado pelos parentes de sua mulher quando tenta restabelecer aliança com os familiares da esposa através do envio de alimentos e do convite para que estes o visitassem.

Dessa forma, a transformação operada por pelo Maire nessa narrativa parece constituir uma punição ao comportamento que desrespeitou as prescrições culturais ou pode ser a revelação da "verdadeira natureza" dos parentes de sua mulher e dele mesmo: no primeiro caso, a natureza animalesca dos primeiros foi revelada, no segundo caso, a natureza divina do herói foi revelada, pois ele se transformou no sol.

A continuidade da narrativa, constituída pela história de seu filho, também trata da regulamentação das relações de parentesco entre os indivíduos do grupo: o filho de Maire- Pochy, ao ver seu pai partir quer seguí-lo para o céu. Ele está seguindo as regras sociais, segundo as quais a linhagem de parentesco é determinada pelo pai ${ }^{191}$, e que o rapaz, a partir de uma certa idade deveria conviver mais tempo com seu pai:

“Os kurumys, ou rapazes, não ficavam mais em casa. Também não dependiam mais diretamente de suas mães, passando a acompanhar os pais, tomando parte de seu trabalho e aprendendo com eles os conhecimentos necessários à vida social., ${ }^{192}$

O desfecho da história se dá pela transformação do homem imprudente que quis experimentar a diadema de chamas em saracura. Ao que parece, este homem passa a pertencer ao reino animal por tentar romper as barreiras que o separavam dos seres celestiais, ao querer usar um ornamento que não era destinado aos homens comuns.

Por fim, no mito sobre as aventuras do neto de Maire-Pochy (que era um dos gêmeos míticos), o tema da transformação dos homens em animais reaparece em uma parte da narrativa, que reproduzimos, para analisá-la com mais atenção:

\footnotetext{
${ }^{190}$ FERNANDES, Florestan. Organização social dos tupinambá. São Paulo: Difusão Européia do Livro, 1963. p.224-5.

${ }^{191}$ FERNANDES, Florestan. Op. Cit. p.191

${ }^{192}$ FERNANDES, Florestan. Op. Cit. p.270.
} 
"A mulher, prosseguindo seu caminho, chega a uma aldeia, cujo chefe tem o nome de Iarnare (...) no qual reconheço a palavra jaguar. Vítima da crueldade dos selvagens, é cortada em pedaços e, depois, devorada. Os filhos são lançados ao lixo, onde os recolhe uma mulher que os cria (...) Indo, certa vez, à procura das iuaias (literalmente, certos frutos arbóreos), os gêmeos decidem vingar a mãe. Com tal objetivo, arrastam os habitantes da aldeia a uma ilha onde, informam, abundam os referidos frutos. No mesmo instante em que os matadores da mãe atravessam a água, os gêmeos provocam uma tempestade, que os submerge e os transforma em animais felinos". 193

No trecho acima transcrito, o tema da salvaguarda da cultura parece ligar-se ao tema da vingança da morte da mãe dos gêmeos. Os gêmeos se vingam de um grupo cujo chefe chamava-se jaguar. As características do jaguar aparecem aqui na forma como a carne da mãe dos gêmeos é preparada antes de ser ingerida: na narrativa fala-se do esquartejamento do corpo, mas não se fala do cozimento da carne. Assim, quando eles promovem a tempestade que transforma esse grupo em animais felinos, o que parece se revelar é a verdadeira natureza desse grupo que, ao que tudo indica come cru. A transformação da tribo que comeu a mãe dos gêmeos em animais, por meio da tempestade, também pode ser interpretada como uma punição à infração ao código cultural segundo o qual se deve comer a carne do inimigo cozida.

Portanto, a representação mítica do Maire está sempre relacionada com a observância das regras instituídas pelo grupo. Na maior parte das narrativas acima descritas, o Maire "puniu" aqueles que desrespeitaram o código cultural transformando-os em animais. A exceção foi constituída pelo caso de Maire-Monan que, se por um lado foi o único Maire a instituir as práticas culturais, por outro, abusou da sua capacidade de transformar homens em animais, quando a usou conforme a sua vontade, sendo por isso, retirado do convívio dos homens. O episódio da morte de Maire-Monan parece constituir uma inversão dos episódios das outras narrativas em que os homens são transformados em animais, pois aqui o Maire é transformado em um corpo celestial por desrespeitar o código cultural.

Em Histórias de Lince, Levi-Strauss retoma os mitos registrados por Thevet que foram acima transcritos, para analisá-los. Esse estudo foi realizado a partir do

${ }^{193}$ MÉTRAUX, Alfred. Op. Cit. p.23. 
questionamento sobre a função simbólica dos gêmeos nos mitos americanos. Assim, o papel que Lévi-Strauss atribui aos heróis míticos dessas narrativas é o de instituidores da origem das diferenças entre os seres que passaram a serem organizados em pares dicotômicos, cujas diferenças, instituídas do primeiro ao quarto demiurgo, vão se tornando cada vez mais sutis:

“Criando o primeiro humano (se é que a palavra convém a uma época em que o povo animal e o povo humano ainda se confundiam), Monan institui uma divisão primordial entre divindades celestes e criaturas terrestres. Maíra-Monan que o sucede, vive entre estas últimas, que, ingratas, provocam uma separação entre brancos e índios. Filho de Maíra-Monan, Sumé e seus filhos, os primeiros gêmeos, repartem os índios em concidadãos (os Tupinambá) e estrangeiros (os Temiminó, inimigos mortais dos Tupinambá). Encarregado da gemeralidade segundo os Guarani contemporâneos, Maíra-Pochy introduz entre os concidadãos uma nova distinção: de um lado os bons, que vivem na fartura, e do outro os maus punidos com a fome. O quinto demiurgo, Maíra, garante a mediação entre o céu e a terra ao se fixar a uma distância adequada desta. Seu filho, Maíra-Ata, sexto e último demiurgo gera o mais belo e mais inteligente gêmeo de um par, enquanto o outro gêmeo, filho de Gambá carrega a tara da ilegitimidade"194

Essas separações realizadas pelo Maire, segundo Lévi-Strauss, seriam aquelas que garantiriam o equilíbrio universal, a partir de pares aparentemente semelhantes, mas essencialmente desiguais, nos quais um termo é sempre superior ao outro, e os gêmeos, na verdade, nunca são realmente gêmeos.

$* * *$

Vimos anteriormente que o Maire associado ao francês é Maire-Monan, segundo o registro de Thevet. Esse herói, possivelmente, é o mais importante dos Maire já que ele seria o responsável pela instituição da cultura nativa, sendo também quem, segundo Lévi-Strauss, teria separado os homens entre brancos e índios, par em que um dos termos seria superior ao outro. Assumindo a hipótese dada por esse autor, a relação entre os franceses e Maire-Monan, teria sido realizada, então, a partir da observação da "superioridade" dos bens materiais possuídos pelos franceses. Assim,

${ }^{194}$ LEVI-STRAUSS, Claude. Histórias de lince. São Paulo: Companhia das Letras, 1993. p.57 
depois de sua partida, possivelmente, ele continuou criando bens culturais na terra onde viviam os franceses.

No registro de Léry sobre a origem da guerra parece ser Maire-Monan, o herói que surge entre os índios e tenta persuadi-los a obedecer ao Deus cristão, pois ele é o único Maire que é associado à instituição das práticas culturais, além de ser o herói do qual descendem os franceses, segundo o registro de Thevet. A atribuição ao estrangeiro da instituição das práticas culturais, aparece no início do mito:

“um mair como vós (...) veio a este país e com as mesmas palavras procurou persuadir-nos a obedecer a vosso Deus, porém, conforme ouvimos de nossos antepassados, nele não acreditaram (...)",195

Dessa forma, o principal código de comunicação com o nativo, a religião cristã, já fora apresentada aos antepassados dos indígenas. Todavia, eles optaram por não seguirem esse código e o primeiro Maire, ao ver o código que ele tentara instituir desrespeitado, vai embora, como o fizeram os outros Maire, quando os homens infringiram as regras estabelecidas pelo grupo.

Logo após a partida do primeiro Maire, veio outro e instituiu uma nova prática cultural entre os índios:

Depois desse veio outro e em sinal de maldição doou-nos o tacape com o qual matamos uns aos outros; e há tanto tempo já o usamos que agora se desistíssemos desse costume as outras nações vizinhas zombariam de nós". ${ }^{196}$

A prática cultural instituída pelo segundo Maire foi aceita pelo grupo, assim como por aqueles grupos que constituíam os inimigos dos indígenas, que passaram, desde então, a cuidar para que o costume fosse mantido entre os nativos.

Os dois Maire presentes nessa narrativa apresentaram duas opções de código cultural para ser seguido pelos nativos: a primeira era o cristianismo que lhes foi apresentada por um antepassado dos franceses e a segunda foi a guerra, que era o elemento do código cultural nativo cuja oposição à religião do estrangeiro, como

${ }^{195}$ LÉRY, Jean de. Op. Cit., p. 168.

${ }^{196}$ LÉRY, Jean de. Op. Cit. P. 168. 
vimos, foi sendo construída ao longo do processo de colonização e, sobretudo, durante as missões.

Dessa forma, essa narrativa parece constituir uma explicação para as diferenças culturais entre índios e franceses, a partir dos dois elementos que são postos em oposição - a saber, a guerra nativa e a religião cristã - pela maior parte dos europeus que tiveram contato com os nativos nos primeiros séculos de colonização.

Além disso, essa narrativa, no contexto em que ela é enunciada - as guerras ainda eram freqüentes, naquele período e naquela localidade - parece constituir uma legitimação de um dos principais ritos indígenas - a guerra - mediante sua condenação verbal e as intervenções dos estrangeiros nesse rito.

Como Sahlins havia sugerido em seu estudo sobre a relação entre mito e história estabelecida pelo encontro entre os maori e os ingleses, aqui, segundo a perspectiva cultural do encontro entre o indígena brasileiro e o europeu, a estrutura que assimilou o evento da vinda dos europeus ao Brasil, também foi modificada por esse evento, tanto em uma possível re-fundação da guerra (mito), quanto em sua execução (rito). 


\section{CAPÍtUlO 3: A GUERRA E A ANTROPOFAGIA SEGUNDO O CÓDIGO CONSTRUÍDO POR FRANCESES E INDÍGENAS NA FRANÇA EQUINOCIAL}

\section{Introdução}

Como apontamos no início do capítulo, o registro sobre a origem da guerra entre os indígenas em d'Abbeville se faz em um contexto bem diferente daquele em que Léry registrou esse mito. Em primeiro lugar, quando d'Abbeville entra em contato com os Tupinambá (1612), já faziam mais de sessenta anos que os jesuítas haviam se estabelecido no Brasil (1549) e, como vimos, os índios com os quais d'Abbeville teve contato conheciam muito bem a posição dos missionários e dos colonos sobre o sistema de vinganças nativo: os primeiros condenaram verbalmente essa prática e interferiram nos rituais. Os segundos utilizaram-se dessas guerras para obterem escravos, além de criarem leis e punições para regulamentar o sistema em função da nova finalidade das guerras coloniais.

Os Tupinambá estabelecidos no Maranhão, como já indicamos, provavelmente tiveram um longo contato com o processo de colonização, conhecendo bem as concepções e as ações dos colonos e dos missionários jesuítas em relação ao seu sistema de vingança. Possivelmente, por isso, ou também pelo pouco tempo que durou essa segunda colônia francesa, (de 1612 a 1616) ${ }^{197}$ quase não há queixas sobre a prática antropofágica nas obras dos dois missionários que escreveram sobre sua experiência de evangelização na França Equinocial, Claude d'Abbeville e Yves d'Evreux.

Além disso, segundo o relato de d'Abbeville, a antropofagia, estava dentre os maus costumes indígenas que os franceses queriam abolir ${ }^{198}$. A restrição a essa prática encontra-se na proposta de aliança feita pelos franceses aos indígenas: logo que os franceses chegaram à ilha do Maranhão, François de Rasily (loco-tenentegeneral do rei francês no Brasil), Charles des Vaux (principal mediador entre lideranças francesas e indígenas) e Claude d’Abbeville (missionário capuchinho), visitaram as aldeias indígenas para reiterarem sua proposta de aliança (que já havia

${ }^{197}$ nossas fontes cobrem apenas o período inicial da colônia, Claude d'Abbeville (4 meses do ano de 1612) e Yves d'Evreux (aproximadamente um ano, entre 1613 à 1614, como indica o título de sua obra).

${ }^{198}$ D’ABBEVILLE, Claude. Op. Cit. p. 234. 
sido feita por Des Vaux, antes da chegada dessa expedição colonizadora). Nesses discursos, segundo d'Abbeville, os franceses mostravam aos indígenas que a antropofagia era contrária à vontade do Deus cristão:

"Deus, porém, na sua infinita misericórdia, condoeu-se deles em meio à sua cegueira odiosa e nos permitiu que lhes déssemos a conhecer a abominação de costume tão diabólico e tão contrário à vontade de Tupã que nos ordena amar aos nossos inimigos.

Também o sr. de Rasilly thes disse o mesmo, mais de uma vez, principalmente durante a primeira reunião na Casa Grande, realizada logo após nossa chegada à Ilha do Maranhão (...)"199

Segundo o relato de d'Abbeville, a aceitação da evangelização era uma cláusula importante do acordo entre franceses e indígenas. Dessa forma, para que a aliança se efetuasse, a reforma dos costumes indígenas era imprescindível. Além de obedecerem ao Deus cristão, cujos mediadores eram os missionários, os nativos deveriam obedecer ao rei francês - "muito grande e poderoso" - através de seu representante no Brasil, "um grande guerreiro e valente capitão", que possuiria também o poder de puni-los caso infringissem alguma das normas impostas. Em troca, os nativos obteriam auxílio na guerra contra as tribos inimigas e contra os portugueses e a manutenção do comércio com os produtos franceses ${ }^{200}$.

Assim, segundo o acordo proposto, o sistema de vinganças indígena deveria ser "fragmentado", os nativos deveriam abandonar a antropofagia, mas poderiam continuar guerreando, só que agora contariam com o apoio militar dos franceses, cujo arsenal garantiria a vitória contra os inimigos indígenas, além de auxiliar os nativos a lutarem contra os portugueses em iguais condições bélicas.

As vantagens alcançadas pelo uso do armamento europeu nas guerras indígenas podem ser vistas em uma passagem em que d'Evreux descreve o ataque empreendido contra os Iura. Segundo d'Evreux, a diferença entre o armamento dos Tupinambá (as armas de fogo) e o dos Iura (arcos e flechas), garantiu que franceses e Tupinambá saíssem apenas feridos do combate. Em compensação, as perdas dentre os Iura foram grandes:

${ }^{199}$ D’ ABBEVILLE, Claude. Op. Cit. p.234.
${ }^{200}$ Ibidem. 
"Sobre alguns dispararam-se tiros de morteiro e de canhão, incendiraram-se-lhes três iuras morrendo nessa ocasião sessenta índios deles, o que somente serviu para aumentar-lhes o desespero, pois antes queriam morrer do que cair nas mãos dos Tupinambás". 201

Pouco antes de descrever o início das guerras que os Tupinambá empreenderam contra seus inimigos com o auxílio dos franceses, d'Evreux relata que os Tupinambá não conseguiriam o apoio dos franceses nas guerras contra os inimigos indígenas, se dentre os motivos da guerra estivesse apenas a vingança. Assim, conhecendo bem os motivos pelos quais os europeus legitimavam a guerra, os indígenas usaram os costumes "abomináveis" de seus inimigos como um argumento que justificava a guerra contra eles:

"todos os principais desses lugares lhe pediram com instância que fosse guerrear os Camarapins, os quais são muito ferozes, não querem paz, e por isso não poupam seus inimigos, pois quando os cativam, matam-nos e comem-nos: poucos dias antes tinham matado três filhinhos de um dos principais dos Tupinambás daquelas regiões, e guardaram os ossos deles para mostrar aos pais a fim de causar-lhes mais dó". ${ }^{202}$

Contudo, o auxílio europeu na guerra e a proibição da antropofagia não eram novidades para os nativos. Segundo o padre Blásquez, missionário jesuíta que estava na Bahia, em 1557, depois do fim da Guerra de Itapuã - entre gentios e colonos -, quando grande parte dos indígenas da região fugiu para o sertão, o governador "propôs" um "acordo" àqueles que ficaram, que implicava no fim da antropofagia e no apoio dos cristãos à guerra indígena:

"Determinou-se o Governador de pôr a mão em este negócio donde tanta honra resultava ao Senhor, e assim mandou um grande língua que se chamava Espinhoso, homem que entre eles tem grande autoridade, a que tentasse esses gentios e visse se por temor se podia acabar com eles a que deixassem tão abominável costume. Prouve ao senhor que desta primeira prática, ficaram eles tais que disseram que lhes mandassem imagens e que fariam igreja aonde as teriam, e que nelas lhes

${ }^{201}$ D'EVREUX, Yves. Op. Cit. p.83.

${ }^{202}$ Ibidem, p.82. 
ensinariam nossos Padres a doutrina e as coisas da fé. Respondeu-lhes a isto que era necessário, se eles queriam ser cristãos, tirassem os impedimentos que estorvassem isto, scilicet, que não matassem os contrários quando fossem à guerra, como fazem as outras nações, e, se por acaso os cativassem, ou que os vendessem ou que se servissem deles como escravos.

Praeterea, que não comessem carne humana, vício tão torpe acerca de Deus e dos homens, e se isto cumprissem que os cristãos seriam seus amigos e os favoreceriam nas guerras e, quando não eles os haviam de destruir de sua terra com a guerra que lhes haviam de fazer". ${ }^{203}$

$\mathrm{Na}$ imposição feita pelo governador aos indígenas que permaneceram convivendo entre os brancos na Bahia, temos, como na proposta dos franceses, a proibição da antropofagia e o apoio militar na guerra. A pré-condição desse apoio opõe o costume da antropofagia aos costumes cristãos. Dessa forma, os nativos, ao abandonarem o antigo costume, estariam aptos a se tornarem cristãos e, como membros dessa comunidade, contariam com o apoio dos colonos cristãos em suas guerras.

Aparentemente, o que se coloca como uma imposição no caso português reforçada pela ameaça da destruição das terras indígenas, e de novas guerras - é apresentada como uma proposta no caso francês - o fim dos antigos costumes em troca de apoio militar e da continuidade do comércio.

A despeito da aparente ausência de coerção na proposta francesa, o acordo parece ser firmado e cumprido pelos indígenas, durante o curto período em que os franceses ficaram no Maranhão. Segundo os relatos de d'Abbeville e d'Evreux, quase não houve resistência por parte dos índios às novas regras impostas pelos franceses. Os casos de infração às novas leis e de questionamento à autoridade francesa relatados nesses textos são raros.

Nas duas fontes temos dois relatos sobre a oposição dos Tupinambá à aliança proposta. Referem-se ao caso já citado de um ancião, chamado Momboré-uaçu, que questiona se os franceses não seriam, afinal, como os portugueses, já que estes também começaram propondo aliança aos índios, comerciando mercadorias e dormindo com suas filhas. Depois propuseram a construção de cidades e trouxeram

${ }^{203}$ LEITE, Serafim. Op. Cit., v.2, p.382-3. 
padres. Finalmente, decidiram escravizar os índios ${ }^{204}$. Esse discurso, feito logo em seguida à proposta de aliança feita por Des Vaux, na casa grande, quando todos os anciãos e seus chefes estavam reunidos, deixou os indígenas propensos a negarem a aliança com os franceses.

Além desse episódio houve o caso de Capitão, um nativo que desejava aprender a língua francesa, dominar a escrita, ser convertido ao cristianismo, aprender os gestos e as cerimônias dos franceses e vestir-se como os padres. Vendo negados os seus pedidos, Capitão sai de aldeia em aldeia falando mal sobre os franceses, exaltando a superioridade do poder dos pajés indígenas em comparação ao poder dos padres e profetizando os males que acometerão os índios caso eles continuassem a aliança com os franceses ${ }^{205}$.

Os casos de infração às lei francesas foram apenas três, segundo informações dessas fontes: um deles foi um homicídio acidental, cometido por um homem contra seu irmão, durante uma cauinagem. ${ }^{206}$ Os outros dois consistiram em ocorrências nas quais o ritual antropofágico por pouco não se concretizou.

Japi-açu, durante uma cauinagem em uma aldeia vizinha, recebe seu filho, com uma de suas escravas presa por ter sido pega em adultério. Diante de tal fato, ele manda matá-la. Um de seus filhos executa sua ordem ${ }^{207}$, a seguir:

"muitos índios, e em especial muitas velhas, esquartejaram-lhe o corpo, sendo mesmo, ao que dizem, enviado um pedaço às escondidas, para a aldeia de Carnaupió." 208

Entretanto, antes que o ritual antropofágico se consumasse, um principal chamado Pirajivá, descobrindo o que aconteceu:

“correu logo ao lugar do assassínio e aí mandou juntar os pedaços do corpo e jogá-los na mata, censurando asperamente os que haviam perpetrado tamanha crueldade. Mas Deus não quis que continuassem tão abomináveis práticas e fez com que chegassem ao nosso conhecimento. ${ }^{209}$

${ }^{204}$ D'ABBEVILLE, Claude. Op. Cit. p.115.

${ }^{205}$ D'Evreux, Yves. Op. Cit. p.85-6.

${ }^{206}$ Ibidem, p. 110.

${ }^{207}$ D'Abbeville, Claude. Op. Cit. p. 132.

${ }^{208}$ Ibidem, p.132.

${ }^{209}$ Ibidem, p. 132. 
Esse caso concentra duas infrações ao código estabelecido pelos franceses. Estes foram cometidos por Japi-açu e por alguns membros da aldeia que visitava. $\mathrm{O}$ primeiro crime foi cometido por Japi-açu que, ao matar a mulher adúltera, executou, ele mesmo, sua punição - segundo as regras dos Tupinambá, o adultério feminino não era tolerado pelo grupo e quando ocorria deveria ser punido com severidade ${ }^{210}$ ao invés de informar aos franceses o que tinha ocorrido e assim esperar que eles administrassem a justiça.

O segundo crime foi a antropofagia que não se consumou: daqueles que quase comeram a carne da escrava assassinada, só foi punido o índio que levou para sua casa um pedaço de seu corpo: de sua casa foram retirados os hóspedes franceses.

Castigo mais severo receberia Japi-açu, segundo d'Abbeville, se não pedisse a intervenção dos padres: pelo homicídio cometido ou talvez pela afronta aos franceses - cometida quando ele mesmo resolveu administrar a justiça - ele foi condenado à morte. ${ }^{211}$ Nesse caso, o homicídio ou a afronta às lideranças francesas pareceu constituir crime mais grave que a antropofagia.

Um episódio em que a antropofagia quase se concretiza é também relatado em d'Evreux:

"Um guerreiro principal, da Ilha do Maranhão chamado Ibuiapointã, quer dizer, Pau-brasil, ao regressar da guerra trouxe consigo alguns escravos, dos quais um procurou salvar-se pela fuga, porém sendo agarrado, foram as velhas ao seu encontro batendo na boca e dizendo 'É nosso, entregai-o, é necessário que seja comido'.

Houve muita dificuldade em salvá-lo, apesar da proibição de não se comerem os escravos, e se não se empregassem ameaças, ele seria devorado pelas velhas". ${ }^{212}$

Nesse caso, como no anterior, não há notícias de punição contra as pessoas que quase comeram o escravo fugitivo.

Em contraposição aos poucos relatos sobre a oposição indígena aos franceses ou sobre o desrespeito às regras ditadas por estes últimos, são abundantes as

\footnotetext{
${ }^{210}$ FERNANDES, Florestan. Organização social dos tupinambá. São Paulo: Difusão Européia do Livro, 1963.p.166-7.

${ }^{211}$ D'ABBEVILLE, Claude. Op. Cit., p.133-5

${ }^{212}$ D'EVREUX, Yves. Op. Cit. p.106.
} 
informações sobre a boa aceitação indígena dos novos costumes e sobretudo, da nova crença trazida pelos missionários capuchinhos. Nos relatos das visitas realizadas, é recorrente em d'Abbeville a descrição da boa disposição com que os índios recebiam os franceses e se dispunham a cumprir os termos do acordo que, como indicamos anteriormente, colocava como pontos principais a conversão dos indígenas ao catolicismo em troca de seu apoio às guerras indígenas.

Essa boa disposição para com o cristianismo pode ser encontrada também nos relatos dos diálogos entre os chefes indígenas, os pajés e o padre Yves d'Evreux. É freqüente nesses diálogos a solicitação de padres que viessem às aldeias indígenas para batizarem seus moradores e ensinarem a religião cristã para seus habitantes; o empenho dos chefes para mobilizarem os indígenas para construírem igrejas; a promessa do bom tratamento que dariam aos padres, não lhes deixando faltar nada; e, sobretudo, e em primeiro lugar, os chefes indígenas pediam o próprio batismo e/ ou o de seus filhos. Muitas vezes os índios pediam para que os padres os ensinassem a serem franceses.

A admiração pela cultura do outro e o desejo de aprender os conhecimentos e as técnicas que, na visão indígena, tornavam o francês "superior", podem ser constatados em diversas passagens dos diálogos entre d'Evreux e as lideranças indígenas.

Pacamão, um famoso pajé indígena, depois de ter investigado sobre os franceses e sobre as causas de sua instalação no Maranhão e, através dessa pesquisa, constatado o prestígio que tinham os padres dentre os indígenas, procura d'Evreux, expõe seus conhecimentos sobre a doutrina cristã ensinada aos nativos e externa seu desejo de se tornar padre:

"Vos outros padres [sois] mais do que nós porque falais a Tupã, e sois temidos pelos espíritos: eis por que quero ser padre". ${ }^{213}$

No entanto, o missionário nega a Pacamão a realização imediata de seu pedido, até mesmo o seu batismo, pois, segundo d'Evreux, seria necessário que Pacamão fosse mais humilde e se arrependesse de suas feitiçarias. ${ }^{214} \mathrm{~A}$ despeito da negativa do padre, Pacamão reitera seu desejo de ser padre e promete voltar no dia

${ }^{213}$ D'EVREUX, Yves. Op. Cit. p.333.

${ }^{214}$ Ibidem, p.335. 
seguinte. Ao retornar, Pacamão toma conhecimento de alguns pontos da doutrina e pede para ser batizado. d'Evreux lhe explica novamente por que ele ainda não estava apto a se tornar cristão e o convida para morar com ele e a abandonar seus antigos costumes. Pacamão aceita o convite. ${ }^{215}$

A insistência de Pacamão em ser padre, apesar dos obstáculos colocados pelo missionário à realização de sua vontade, parece comprovar o valor que tinha o papel do missionário e de seus conhecimentos naquele momento.

Um outro pajé, que coordenava a construção das fortificações dos franceses, mais informado que Pacamão sobre o modo de tratar os padres, demonstra-se contente com a evangelização das crianças indígenas que, a seu ver, melhoraria a sorte destas. Ao que o padre responde, confirmando a felicidade que os indígenas irão gozar com a:

"vinda de socorros e navios de França trazendo muitos padres, muitos franceses, muita ferramenta e gêneros para eles: que então se construiriam casas a maneira dos franceses, que seriam acompanhados por eles quando fossem guerrear contra os inimigos, que viriam os Tupinambá e os outros aliados cultivar a terra da ilha, e que tudo isso poderiam ver antes de morrerem". ${ }^{216}$

Segundo d'Evreux, a idéia de que os costumes, a língua, a crença e os bens materiais dos franceses trariam mais felicidade aos filhos dos indígenas era muito comum entre os nativos, que a expressavam durante as conversas que tinham com o padre:

"Nós o que temos feito é correr e andar errantes pelos bosques adiante dos pêros, tendo por alimento apenas raízes de árvores. Nossos filhos estarão mais seguros contra seus inimigos, os franceses se unirão às nossas filhas, e nossos filhos às filhas dos franceses, e assim seremos parentes; ficareis conosco, em nossas aldeias, e sereis nossos padres, Tupã os amará, e Jeropari nada poderá contra eles. Haverá abundância de víveres e nunca se sentirá falta de mercadorias francesas". 217

“Oh! Quanto serão felizes! Porém nós não veremos essas coisas”. 218

\footnotetext{
${ }^{215}$ D'EVREUX, Yves. Op. Cit. p.337-41.

${ }^{216}$ Ibidem, p. 344.

${ }^{217}$ Ibidem, p. 285.

218 Ibidem.
} 
Ao que tudo indica a crença cristã era, aos olhos indígenas, um importante elemento a ser conhecido para se alcançar a felicidade. Entretanto, nem sempre os nativos conseguiram dissociar a crença dos outros componentes da cultura do estrangeiro que lhes eram apresentados.

Onda, um principal indígena, parece ter associado o conhecimento da língua francesa ao conhecimento da doutrina cristã, quando julgou que seu filho estava pronto para ser batizado, pois, a seu ver, conhecia bem a língua francesa ${ }^{219}$. Assim, quando o padre conseguiu lhe convencer de que os conhecimentos de seu filho não bastavam para que ele se tornasse "caraíba", resolveu deixar o rapaz com o padre recomendando-lhe:

"que escutasse bem tudo quanto lhe ensinassem, que não perdesse uma só palavra, $e$ que imitasse todas as ações dos franceses, que viria depois buscá-lo para a terra dele, a fim de ensinar-lhe o que tivesse aprendido". ${ }^{220}$

Por fim, a fala de Iacupém, um principal de uma tribo que acabara de se aliar aos franceses e aos Tupinambá (seus antigos inimigos), parece associar a riqueza material dos franceses ao conhecimento do Deus cristão, ao relacionar sua pobreza ao desconhecimento desse Deus:

"nós vivemos errantes e vagabundos, sem roupas, machados, foices, facas e outras ferramentas" (...)

"Nascem ao mesmo tempo dois meninos, um francês, e outro Tupinambá, ambos doentes e fracos, e não obstante um nasce para gozar de todas as comodidades, e o outro para viver pobremente” (...)

"Não posso tranqüilizar meu espírito, quando penso que vós outros franceses tendes mais conhecimentos de Deus do que nós. Por que temos vivido tanto tempo na ignorância?",221

Essa valorização da cultura do outro, juntamente com o empenho dos indígenas em conhecê-la talvez possa ser relacionada com os motivos que levaram os Tupinambá a se aliarem aos franceses - os nativos talvez quisessem obter dos

\footnotetext{
${ }^{219}$ D'EVREUX, Yves. Op. Cit. p.360.

${ }^{220}$ Ibidem, p.362.

${ }^{221}$ Ibidem, p.352.
} 
franceses todos os instrumentos que eles pensavam serem eficazes para construírem relações igualitárias com os europeus, ou seja, a escrita, as armas de fogo, as ferramentas agrícolas e as roupas. John Monteiro, em sua análise da explicação indígena sobre as diferenças entre brancos e índios registrada presente na narrativa sobre a espada de madeira, destaca que:

"Diante de condições crescentemente desfavoráveis, as lideranças nativas esboçavam respostas das mais variadas, freqüentemente lançando mão dos instrumentos introduzidos pelos colonizadores. A resistência, nesse sentido, não se limitava ao apego ferrenho às tradições pré-coloniais, mas, antes, ganhava força e sentido com a abertura para a inovação". ${ }^{222}$

Assim, podemos ler a boa vontade indígena para com os padres capuchinhos e a sua doutrina como uma estratégia de adaptação nativa para responder às novas demandas impostas pela realidade colonial: o longo período em que eles tiveram contato com o processo colonial e com os missionários jesuítas, possivelmente, os levou a associar o poder material e bélico dos colonizadores com a religião cristã.

É nesse contexto que os Tupinambá realizaram sua aliança com os franceses, segundo a qual eles se propuseram a reformarem seus costumes e a se submeterem às lideranças francesas - como vimos, isso implicava o abandono do ritual antropofágico - em troca dos conhecimentos e dos instrumentos que eles pensavam serem necessários, naquele momento, para se adaptarem às novas circunstâncias.

A narrativa sobre a origem da guerra registrada por d'Abbeville é enunciada por Japi-açu, em resposta à aliança proposta pelos franceses, talvez com o intuito de demonstrar para os franceses que os indígenas pertenciam, nos tempos primordiais, ao mesmo grupo dos franceses, já que eram descendentes dos mesmos ancestrais e, principalmente, por conhecerem, desde esse período, o Deus dos franceses, ao qual optaram por não obedecer naquele período.

Portanto, essa narrativa muda um pouco em relação à versão registrada por Léry. Contudo, um aspecto parece se manter: ambas relacionam uma escolha cultural ao início da diversidade entre indígenas e europeus. Essa escolha é traduzida nos dois

\footnotetext{
${ }^{222}$ MONTEIRO, John. A espada de madeira. In: PINTO, Zélio Alves (org.) Cadernos Paulistas: história e personagens. São Paulo: SENAC; IMESP, 2002. p.28-31.
} 
registros como a opção entre obedecer ao Deus cristão ou ao Diabo, relacionando assim, o início da guerra com a opção indígena de obediência ao Diabo.

Entretanto, antes de desenvolvermos a análise dessa segunda narrativa e de seu tema comum com a primeira, refaremos o mesmo percurso que se inicia com a análise das concepções dos missionários capuchinhos sobre a guerra nativa.

\section{A guerra e a antropofagia segundo as obras de Yves d'Evreux e Claude d'Abbeville}

As discussões realizadas sobre a antropofagia indígena a partir da obra do dominicano Francisco de Vitoria, De indis ${ }^{223}$, até o estudo do jesuíta José de Acosta, Historia natural y moral de las Indias ${ }^{224}$, parecem influenciar as concepções de Claude d'Abbeville e de Yves d'Evreux sobre esse tema. Estas obras são unânimes em apontar a antropofagia como uma inversão da razão natural. No entanto, como veremos a seguir, as obras de Francisco de Vitoria e de José de Acosta, divergem quanto à causa dessa inversão: enquanto o primeiro deduz que a inversão ocorreria

por uma falha educacional (de acordo com o princípio aristotélico de Educação) ${ }^{225}$, o segundo associa a antropofagia a um erro induzido pela ação do Diabo, que dominaria a América, antes da chegada dos primeiros europeus.

Entre as obras de Vitoria (1539) e de Acosta (1590) se interpõem mais de cinquienta anos nos quais os relatos sobre a religião de alguns povos americanos (dentre eles, os Tupinambá), passaram da perplexidade diante da constatação de poucos elementos que poderiam ser associados aos sinais de alguma religiosidade, à associação da figura do pajé, de alguns ritos e de algumas crenças, à idolatria. Para essa "mudança" de perspectiva sobre a "religiosidade" indígena contribuíram não só a construção dos códigos compartilhados durante a catequese, mas também o esforço realizado por alguns europeus incumbidos de resolver a questão da "religiosidade" do homem americano.

Como apontaram vários estudos, os relatos sobre a "religiosidade" dos índios brasileiros oscilaram entre a afirmação sobre a ausência de "religião" e a constatação

\footnotetext{
${ }^{223}$ VITORIA, Francisco de. Relectio 'Des Indes'. Madri: L. Pereña; J. M. Pérez Prendez, 1967. ${ }^{224}$ ACOSTA, José de. Historia natural y moral de las Índias. México: ed. Edmundo O’ Gorman, 1962.

${ }^{225}$ PAGDEN, Anthony. Op. Cit., p.99.
} 
da adoração ao demônio por intermédio dos pajés indígenas. Segundo Gruzinski, Las Casas resolveu a questão da "religiosidade" dos indígenas brasileiros, associando suas crenças ao domínio do Diabo no Brasil e assim, à idolatria, que assume aqui o sentido de adoração ao Diabo:

“O Brasil constitui um novo obstáculo a ser superado e explicado: lá não há ídolos, nem sequer conhecimento de Deus. Se trataria por acaso de um estado pré-religioso ou sem religião e, por conseguinte, não previsto pela rede? Não, porque os informantes descrevem um culto ao trovão (...) e sobretudo falam de uma crença em feiticeiros vindos de outro mundo que são, ao mesmo tempo, os profetas de um mundo melhor no qual o homem deixará de trabalhar, e médicos que curam as enfermidades. Esses feiticeiros provocam crises de possessão e utilizam a ventríloquia. "226

Logo, as crônicas sobre os povos do Brasil:

"Longe de questionar a rede, o testemunho brasileiro (de origem jesuíta) corrobora a lição das Ilhas e do continente ao mostrar que foi através dos 'ministros e sacerdotes' indígenas como o demônio difundiu a idolatria, como se o intermédio dos homens tivesse precedido a do ídolo". 227

Segundo os documentos analisados por Vainfas na obra $A$ heresia dos índio, a idolatria foi identificada às insurgências indígenas contra o colonialismo, ou seja, na "obediência" indígena a seus pajés que, segundo os missionários, eram os representantes do Diabo no Brasil, pois eram propagadores do "profetismo tupi", que procurava opor os índios à catequese e aos padres:

"Diante da pregação de certos pajés (...) jesuitas e outros cronistas não deixaram de ver feitiçaria e até idolatria, contrariando completamente a sua opinião de que os tupi não criam em coisa alguma". 228

${ }^{226}$ BERNAND, Carmen; GRUZINSKI, Serge. De la idolatría. Una arqueologia de las ciencias religiosas. México: Fondo de Cultura Económica, p.70.

227 Ibidem, p.70.

${ }^{228}$ VAINFAS, Ronaldo. A heresia dos índios: catolicismo e rebeldia no Brasil colonial. São Paulo: Companhia das Letras, 1995. p.30. 
As análises de Vainfas e de Gruzinski apontam para o fato dos cronistas, observando as sociedades indígenas brasileiras a partir de um esforço para definir o lugar desses povos na história bíblica, terem encontrado na demonização da "religião" indígena, propagada pelos pajés, tanto a legitimação para um projeto de evangelização dos indígenas, quanto seu enquadramento dentro de uma realidade conhecida.

No entanto, isso que os missionários denominaram como idolatria, ou seja, a oposição indígena à catequese, a partir de um código, difundido pelos pajés, que assimilou algumas crenças e ritos ensinados pelos padres, ou as próprias crenças ensinadas pelos pajés, foram, como parece indicar a obra de Pompa, uma construção realizada entre missionários jesuítas e indígenas durante a catequese, através do uso de alguns termos indígenas para traduzirem alguns conteúdos do catolicismo e da imitação de alguns gestos e palavras dos pajés indígenas. ${ }^{229}$

Além da "religiosidade", as fontes mostram que outros aspectos da cultura indígena foram demonizados, sendo os hábitos indígenas, sobretudo a guerra e a antropofagia, os principais. Estes foram condenados ao serem lidos com base nos textos bíblicos. Assim, a explicação dada para o início destes costumes foi o abandono dos indígenas à religião cristã e o início de sua obediência ao Diabo, como vimos na análise do registro sobre a origem da guerra em Léry.

Como tentamos brevemente demonstrar, a demonização da "religiosidade" e dos costumes indígenas foram uma construção dos missionários ao longo da evangelização, enquanto tentativa de solucionar a questão da diferença representada pelo Tupinambá. Portanto, os diferentes contextos em que Vitoria e Acosta analisaram a questão da antropofagia indígena parecem ter contribuído para as diferenças entre as teorias que estes autores formularam para explicar as causas desse hábito.

Outro fator que influenciou as diferenças entre os estudos de Francisco de Vitoria e José de Acosta tem relação com os problemas que eles se propuseram a responder: Francisco de Vitoria analisa o tema da antropofagia indígena utilizando a filosofia moral como base para responder às questões teológicas, a partir da preocupação, compartilhada por sua escola,

${ }^{229}$ POMPA, Cristina. Op. Cit., p.53. 
"com a necessidade de descrever e explicar o mundo natural, e o lugar do homem nele, nos mesmos termos racionalistas que Tomas de Aquino usou na Summa contra gentiles". 230

Segundo a qual:

"a lei da natureza era a causa eficiente que determinava o relacionamento do homem com o mundo e governava toda prática na sociedade humana. Ela sozinha poderia prover as bases para os julgamentos éticos naquelas áreas onde não existiam regras prévias, assim como ela oferecia uma explicação racional para todas as regras existentes". 231

Assim, segundo Pagden, Francisco de Vitoria concebia o canibalismo como um crime contra as leis da natureza, que ocorreria pelo fato do código alimentar pertencer a um campo em que as leis da natureza não eram óbvias, a secunda praecepta, da qual se originavam todas as normas e leis promulgadas pela comunidade. Esse conjunto normativo deveria ser deduzido pelo intelecto humano que, por constituir um instrumento imperfeito, poderia levar o homem a deduzir uma falsa praecepta. Esse tipo de erro seria mais raro entre os cristãos, já que eles eram guiados pela revelação. Por sua vez, os homens que não fossem guiados pela "verdadeira religião", seriam conduzidos mais facilmente à violação dos códigos pertencentes a essa instância das leis naturais. ${ }^{232}$

Esse é o argumento central de Vitoria para explicar por que alguns povos americanos praticavam uma ação tão contrária às leis da natureza e, por conseguinte, às leis cristãs. Dessa forma, ele não nega a presença da razão dentre seus praticantes, a despeito do anti-naturalismo que ele atribuía a essa ação, que ofendia não somente a natureza racional do homem, mas também sua natureza animal. ${ }^{233}$

Portanto, para Vitoria, a prática da antropofagia, costume mais condenado pelos europeus, não era argumento para se afirmar a ausência de razão entre seus praticantes. No entanto, sua ocorrência mostrava que a razão existente entre os

\footnotetext{
${ }^{230}$ PAGDEN, Anthony. Op. Cit. p.61.

${ }^{231}$ Ibidem.

${ }^{232}$ Ibidem, p.93-9.

${ }^{233}$ Ibidem, p.86.
} 
indígenas era apenas potencial: para que ela operasse de fato seria necessário que os indígenas fossem educados, segundo a concepção aristotélica que entendia a educação como a prática que institui os hábitos e "o treinamento do intelecto especulativo' até ele se tornar capaz, de forma acurada e sem necessidade de ajuda, de deduzir a secunda praecepta". ${ }^{234}$

Como apontamos anteriormente, para Vitoria a violação dos códigos que compõem essa instância das leis naturais é rara dentre aqueles que são instruídos nas leis cristãs. ${ }^{235}$ Assim, a teoria que este autor formula para explicar a alteridade das culturas americanas parece responder às demandas dos missionários que trabalhavam pela evangelização dos povos do Novo Mundo, já que afirma que os americanos são dotados de razão em estado potencial que, se educada, ou seja, se eles forem civilizados e evangelizados, pode torná-los homens que poderão ser nivelados aos europeus.

Conforme constatou Pagden, as obras de Francisco de Vitoria e de seus sucessores constituem a base intelectual dos estudos do jesuíta José de Acosta sobre os americanos. Entretanto, sua visão sobre o índio é também influenciada pela sua experiência como missionário no Lago Titicaca no ano de 1578: nesse período o missionário preocupou-se em entender o funcionamento interno da sociedade indígena para encontrar o melhor modo de civilizá-la.

Assim, sua formação intelectual e sua experiência como missionário parecem explicar o fato da sua visão sobre a antropofagia indígena situar-se entre as concepções de Vitoria e aquela dos missionários jesuítas sobre essa prática, associando a antropofagia a uma inversão da lei natural (como Vitoria) que ocorreria devido à ação demoníaca sobre os indígenas:

“A mais dramática, mais ofensiva, instância da poluição satânica era o canibalismo. O canibalismo foi associado ao desejo satânico (...) baseado no mesmo tipo de erro mental que faz com que o homem idolatre as imagens de madeira como se fossem deuses". 236

Em Acosta, a ação demoníaca explicava não somente os maus costumes indígenas, mas também a presença de leis e costumes similares aos europeus, além

\footnotetext{
${ }^{234}$ PAGDEN, Antony. Op. Cit. p. 99.

${ }^{235}$ Ibidem.

${ }^{236}$ Ibidem, p. 176.
} 
da "apropriação" das religiões indígenas de alguns elementos da crença e do ritual católico. Dessa forma, o domínio do Diabo na América explicava tanto as semelhanças - em alguns casos, já existentes entre os índios antes do contato com os europeus, em outros casos, aprendidos a partir do contato - quanto as diferenças entre europeus e americanos. ${ }^{237}$

Assim, como apontamos anteriormente, se Acosta e Vitoria entreviam na antropofagia uma inversão da lei natural, as causas que esses autores atribuíram para essa inversão são distintas: onde Vitoria verificou a carência de uma educação que habilitasse os indígenas a deduzirem corretamente a secunda praecepta, Acosta constatou a ação demoníaca, compartilhando a visão da maior parte dos missionários e dos outros cronistas que vieram para o Novo Mundo.

O juízo de Acosta sobre a antropofagia indígena parece aproximar-se das concepções de d'Abbeville e de d'Evreux, na medida em que se trata de uma idéia compartilhada pelos missionários, segundo a qual os maus costumes indígenas que inviabilizavam a conversão - dentre eles a antropofagia - eram oriundos do domínio do Diabo sobre as populações americanas.

Na obra de d'Abbeville, essa visão sobre a antropofagia pode ser apreendida no relato das visitas diplomáticas às aldeias indígenas. Na aldeia de Juniparã, durante a proposição da aliança, os franceses questionaram se os Tupinambá:

“(...) queriam renunciar a Jurupari e a seus diabólicos costumes: comer carne humana, matar a sangue frio os inimigos, ter muitas mulheres e outras coisas que haviam aprendido de seus pais a quem as ensinara Jurupari”. ${ }^{238}$

A despeito do fato de d'Abbeville dedicar um capítulo inteiro de sua obra para tratar "das vinganças e guerras dos maranhenses", a idéia de que a antropofagia era um costume condenável aos olhos dos cristãos por ferir os mandamentos da igreja - segundo os quais se deve perdoar os inimigos e não se deve matar - e que por isso, só pode ser um costume inspirado pelo demônio, constitui o único juízo que esse autor profere sobre a guerra indígena.

As menções à antropofagia em d'Abbeville são breves, elas se restringem à citação feita há pouco; às passagens já citadas na seção anterior, que foram o

\footnotetext{
${ }^{237}$ PAGDEN, Anthony. Op. Cit. p.174-5.

${ }^{238}$ D’ABBEVILLE, Claude. Op. Cit., p.100.
} 
comentário ao capítulo dedicado a esse tema e o relato do caso de antropofagia que quase ocorreu; e no aval que o missionário dá às palavras de Japi-açu sobre a origem da guerra que, como veremos, concebe-a como a realização da vontade de Jurupari. $^{239}$

A associação entre a antropofagia e a ação diabólica, como comentamos há pouco, está presente também na obra de d'Evreux. No elogio à perfeição dos corpos dos indígenas, ele comenta:

"Se o Diabo, com o fim de roubar-lhes o bem da salvação, não se metesse entre eles, levantando novas discórdias a fim de se matarem e comerem reciprocamente, não haveria por certo homens mais felizes no mundo por causa de sua natural franqueza e liberdade, que, adubando as suas carnes as transformam em perfeita e saudável nutrição, e daí provém a beleza de seus corpos". ${ }^{240}$

Nesse comentário, como também em toda a obra de D’Evreux, a ação demoníaca torna imperfeitas as obras da natureza. Dessa forma, os indígenas, mais próximos do estado de natureza do que do estado de cultura, são dominados pelo Demônio por desconhecerem os instrumentos usados pela cultura para extirpá-lo, ou seja, por não terem o conhecimento do Deus cristão.

Portanto a visão de D’Evreux sobre a antropofagia indígena parece se situar entre as concepções de Vitoria e de Acosta. Como Acosta e os outros europeus que tiveram contato direto com esse costume, D'Evreux atribuí o costume à ação diabólica. No entanto, em d'Evreux a demonização desse costume parece ser amenizada quando ele o atribui ao fato do indígena ser um homem mais próximo do estado de natureza do que da cultura.

A concepção do índio como um homem natural parece figurar aqui como uma forma de relativizar a antropofagia e assim demonstrar que os indígenas eram dotados das mesmas faculdades mentais dos franceses. Assim, dentre as causas da antropofagia o autor exclui a concepção - muito comum nos relatos sobre as guerras indígenas - segundo a qual este costume ocorreria devido à ausência de razão dentre os índios:

${ }^{239}$ D'ABBEVILLE, Claude. OP. Cit. p.61.

${ }^{240}$ D'EVREUX, Yves. Op. Cit. p.150. 
"Se me disserdes que eles fazem ações inteiramente brutais, como as de comer seus inimigos e praticar tudo que os ofenda, como seja expô-los em lugares onde há piolhos, vermes, espinhos, etc., eu vos responderei não porvir isto da falta de juízo, porém sim de um erro hereditário, sempre existente entre eles, por pensarem que sua honra depende de vingança: parece-me também que não é desculpável o erro dos nossos franceses de se matarem em duelo, e, contudo, vemos os mais belos espíritos e os primeiros da nobreza concordarem com este erro, desprezando a Lei de Deus e arriscando a eternidade de sua salvação". ${ }^{241}$

Esta idéia segundo a qual a antropofagia não era uma prática que ocorria por conta da ausência de razão dentre os americanos, como vimos, estava presente na obra de Vitoria, assim como a relativização desse costume estava presente na obra de Léry, através da comparação com outros costumes europeus, tão abomináveis quanto o canibalismo.

Além disso, d'Evreux (talvez também d'Abbeville) parece concordar com Vitoria a respeito do papel da educação - através da civilização dos costumes e do aprendizado do cristianismo - para favorecer a abolição da antropofagia. No entanto, d'Evreux acreditava que quando os franceses forem embora esse costume voltaria a ser praticado dentre os indígenas.

Acreditamos que essa afirmação de d'Evreux, longe de negar a idéia de Vitoria sobre a eficácia da educação na mudança dos maus costumes dos indígenas que depois de instituída proporcionaria autonomia aos indígenas ${ }^{242}$ - tenha relação com seu conhecimento da situação da colônia francesa no Brasil que, desde o início parecia fadada a sucumbir já que perdera o apoio da rainha ${ }^{243}$. Além disso, essa afirmação do missionário parece expressar suas dúvidas a respeito da capacidade dos portugueses em evangelizarem os índios.

Portanto, os registros franceses sobre a guerra e a antropofagia indígena, realizados pelos missionários que vieram evangelizar os indígenas da Ilha do Maranhão, parecem ter sido influenciados tanto pelas discussões européias sobre esse costume - ocorridas no século anterior - quanto pela compreensão do nativo a respeito das concepções européias sobre o seu sistema de vinganças, já bastante

\footnotetext{
${ }^{241}$ D'EVREUX, Yves. Op. Cit. p. 121.

242 PAGDEN, Anthony. Op. Cit. p.104.

${ }^{243}$ HOLLANDA, Sérgio Buarque (org.). Op. Cit.
} 
consolidada pelo contato deste com os missionários jesuítas e com os colonos portugueses.

Assim, como veremos a seguir o registro realizado por d'Abbeville da fala de Japi-Açu a respeito da origem da guerra entre os indígenas parece situar-se entre a re-fundação mítica de um costume que foi discutido e condenado a partir do contato - como foi o caso do fragmento mítico registrado por Léry - e uma estratégia desse líder indígena para não perder o apoio das lideranças francesas: Japi-açu, em sua fala, concebe a guerra como um costume inspirado pelo Diabo.

\section{A origem da guerra, segundo os Tupinambá}

"Acreditamos ainda que por causa da maldade dos homens e para castigar-nos Deus fez o Dilúvio, apenas escapando um bom pai e uma boa mãe de quem descendemos todos. Éramos uma só nação, vós e nós; mas Deus, tempos após o dilúvio, enviou seus profetas de barbas para instruir-nos na lei de Deus.

Apresentaram êsses profetas ao nosso pai do qual descendemos, duas espadas, uma de madeira, outra de ferro e lhe permitiram escolher. Êle achou que a espada de ferro era pesada demais e preferiu a de pau. Diante disso, o pai de quem descendestes, mais arguto, tomou a de ferro. Desde então fomos miseráveis, pois os profetas, vendo que os de nossa nação não queriam acreditar nêles, subiram para o céu, deixando as marcas de seus pés cravadas com cruzes no rochedo próximo de Potiiú, que tu viste tão bem quanto eu (disse dirigindo-se a Migan)

Depois disso surgiu entre nós a diversidade das línguas, pois antes tínhamos a mesma. De modo que [não] nos entendendo mais, massacramo-nos e comemos uns aos outros, fazendo o jogo de Jurupari". ${ }^{244}$ [grifo meu]

No trecho acima transcrito, a origem da guerra é narrada somente nas três últimas linhas. Contudo, achamos importante recuar o recorte, nele incluindo todos os motivos míticos proferidos por Japi-Açu, pois isso nos auxiliará a compreender melhor essa versão mítica sobre a origem da guerra, na medida em que esta última é concebida como conseqüência de uma opção nativa e narrada dentro de um discurso que procurou fundamentar a aceitação indígena da proposta francesa de aliança.

Nesse sentido, acreditamos que as narrativas presentes no discurso de JapiAçu situam-se entre a exposição de um código construído por jesuítas e nativos no

${ }^{244}$ D’ABBEVILLE, Claude. Op. Cit. p.60-1. 
contexto das missões, como sugeriu Montero $^{245}$, e uma possível re-fundação da mitologia indígena realizada para dar conta da realidade conhecida a partir do encontro com a alteridade européia, nos termos propostos por De Martino.

Como apontamos anteriormente, a chegada dos europeus, a intensificação do processo de colonização do Brasil e, sobretudo, as missões trouxeram uma série de elementos não previstos pela mitologia nativa que, por isso, necessitavam ser repensados e re-fundados pelo mito e pelo rito das sociedades indígenas. Como demonstrou Pompa, a linguagem religiosa dos missionários jesuítas foi a principal intermediária da comunicação entre missionários e nativos ${ }^{246}$. Dessa forma, essa linguagem forneceu a maior parte dos elementos para os nativos re-pensarem os próprios mitos, além de apresentar os conteúdos que ensinava aos indígenas como importantes elementos da cultura do outro, contribuindo assim tanto para uma possível re-fundação da realidade indígena, quanto no fornecimento dos instrumentos necessários para os indígenas interagirem com a nova realidade.

No início do capítulo vimos que a versão mítica sobre a origem da guerra que analisaremos a seguir foi registrada por d'Abbeville no contexto das visitas diplomáticas francesas que tinham o intuito de propor uma aliança entre franceses e indígenas, segundo a qual, em troca da continuidade do comércio e do apoio francês nas guerras indígenas, principalmente contra os portugueses, os nativos deveriam mudar seus costumes, suas "crenças", passando a obedecer aos chefes franceses que foram para o Maranhão como representantes da vontade do seu rei francês e aos padres que representavam a vontade do deus cristão.

Assim, na proposta feita pelos franceses, a aceitação da evangelização e a mudança dos costumes indígenas - ambos projetos dos missionários jesuítas com os quais os nativos provavelmente tiveram contato - constituem cláusulas importantes de um acordo que, segundo os relatos de d'Evreux e de d'Abbeville, era desejado pelos nativos. Essa boa vontade nativa em relação à proposta francesa pode ser encontrada no início do discurso que Japi-Açu fez durante a reunião, por ele convocada, entre lideranças francesas e indígenas, na qual ele proferiu a narrativa que citamos no início dessa seção. Nessa fala, Japi-Açu demonstra conhecer bem os termos do acordo a ser firmado e concordar com a proposta dos franceses ${ }^{247}$.

\footnotetext{
${ }^{245}$ MONTERO, Paula. Op. Cit.

246246 POMPA, Cristina. Op. Cit., p. 25

${ }^{247}$ D' ABBEVILLE, Claude. Op. Cit., p.59.
} 
Segundo seu discurso, a vinda dos colonizadores franceses era aguardada com ansiedade e o principal motivo do apreço dos indígenas pela presença francesa na região era o temor da chegada dos portugueses:

"Já começávamos a nos aborrecer por não vermos chegar os guerreiros franceses sob o comando de um grande morubixaba; já tínhamos resolvido deixar esta costa e abandonar esta região com receio dos peró, nossos inimigos mortais, e havíamos deliberado embrenhar-nos por esta terra a dentro até onde jamais cristão nos visse, e estávamos decididos a passar o resto de nossos dias longe dos franceses, nossos bons amigos, sem mais pensarmos em foices, machados, facas e outras mercadorias". 248

$\mathrm{O}$ apoio bélico dos franceses, naquele momento, parecia ser uma das poucas chances dos indígenas vencerem o inimigo português: o período em que os nativos tiveram contato com estes últimos os fez perceberem que não poderiam vencer uma guerra contra os portugueses com as mesmas armas usadas nas guerras inter-tribais. Além disso, os indígenas apreciavam os bens materiais obtidos através do comércio com os franceses (facas, foices, machados, etc.). Portanto, parte dos interesses indígenas na aliança proposta parece se ligar ao fato deles conceberem a cultura material do estrangeiro, como "superior" a própria cultura e necessária para a sobrevivência do grupo naquele momento.

A resposta de Japi-Açu à proposta segundo a qual o apoio material dos franceses seria trocado pela submissão indígena ao rei francês (representado pelos chefes militares da colônia) e ao deus cristão (representado pelos padres) demonstra que para ele os bens materiais do estrangeiro estavam vinculados ao poder do deus desse estrangeiro. Dessa forma, uma das obrigações impostas aos indígenas - a aceitação da evangelização - era inseparável dos benefícios que eles obteriam a partir desse acordo. Em outras palavras, tanto a evangelização, quanto os bens materiais do outro foram concebidos como termos inseparáveis que, naquele contexto, eram também instrumentos necessários para a adaptação do grupo aos novos tempos.

Uma associação entre a "superioridade" da cultura material européia e o poder do Deus cristão foi realizada pelo Irmão Pero Correa durante a primeira década

${ }^{248}$ D' ABBEVILLE, Claude. Op. Cit., p.59-60. 
das missões jesuítas, como parte da tentativa do missionário de persuadir os indígenas a mudarem seus costumes e a obedecerem ao deus dos missionários. Em carta de 1553, o padre conta que:

"Eu tenho dito a alguns índios principais destas partes algumas coisas sobre mandar o Rei que não lhes dêem facas grandes nem pequenas da Alemanha, nem outras armas (...) porque não é certo que as coisas boas que Deus criou sejam dadas aqueles que não conhecem a Deus, (...) Não lhes parece mau isso que eu digo, nem eles me contradizem, mas antes me dizem que os façamos cristãos e lhes ensinemos tudo o que é necessário, pois eles querem ser nossos irmãos". ${ }^{249}$

No ano seguinte, o Irmão Pero Correa relata que a descoberta de uma mina de ferro em São Vicente possibilitou que os padres em suas pregações aos índios associassem esse acontecimento ao fato dos nativos terem começado a crer em Deus:

"Há poucos dias, quando lhes começaram a pregar a fé, davam-lhes a certeza de que se acreditassem em Deus que não somente lhes daria nosso Senhor as grandes coisas celestiais, que tinha para os seus, mas que neste mundo em suas terras e lugares lhes daria muitas coisas que estavam escondidas, que eles tinham debaixo dos pés, as quais Deus não queria que eles conhecessem porque não conheciam o Criador delas, e que também não as mostrava aos cristãos porque ofendiam o Criador; mas que se eles acreditassem em Deus, que Deus as daria. Agora acontece que depois deles começarem a serem cristãos, deu nosso Senhor uma mina de ferro em sua terra, e eles mesmos assim pregam uns aos outros". 250

Apesar destes constituírem os únicos relatos que encontramos nas fontes jesuítas sobre a associação, durante as pregações, entre riqueza material e o poder do deus cristão, acreditamos que esse tenha sido um código construído por missionários e indígenas para explicar a pobreza material destes últimos e para convencê-los a aceitarem a evangelização, já que essa idéia surge com bastante frequiência nos relatos que d'Evreux e d' Abbeville fizeram dos diálogos que tiveram com as lideranças indígenas.

${ }^{249}$ LEITE, Serafim. Op. Cit., v.1, p.444-5. (original em espanhol; carta escrita pelo Irmão Pero Correa ao [P. Simão Rodrigues] em São Vicente em março de 1553).

${ }^{250}$ LEITE, Serafim. Op. Cit., v.2, p.70. (original em espanhol; carta escrita pelo Irmão Pero Rodrigues ao [P. Brás Lourenço] em São Vicente em julho de 1554). 
Portanto, tudo indica que no contexto em que o mito foi proferido, os indígenas tinham grande interesse nos bens materiais oferecidos pelo estrangeiro e, principalmente, no apoio deste último em suas guerras, enquanto instrumentos necessários para sua adaptação às novas demandas impostas pela presença européia.

Além disso, como vimos, esses bens materiais e mesmo a vitória indígena nas guerras inter-tribais, possivelmente, foram vinculados ao poder do deus dos europeus. Em outras palavras, na tentativa de catequização dos indígenas prometeu-se a vitória contra os inimigos e a abundância de alimentos e mercadorias européias que foram apresentadas aos nativos como criações do deus dos estrangeiros feitos para aqueles que nele acreditavam e a ele obedeciam.

Nesse sentido, a presença dos ensinamentos jesuítas na narrativa enunciada por Japi-Açu pode ser entendida como uma fundação mítica da aliança que se estava firmando entre franceses e indígenas, a partir da síntese dos motivos míticos presentes entre os indígenas pelo menos desde a primeira visita de Thevet ao Brasil com os elementos que os indígenas conheceram a partir da missão.

Retomando a narrativa transcrita no início dessa seção, veremos que ela repete alguns motivos míticos registrados por Thevet nas Singularidades da França Antártica $(1557)^{251}$ e na Cosmographie Universelle $(1575)^{252}$, com ênfase nos temas que nos relatos jesuítas aparecem como sinais da presença de alguma "religiosidade" dentre os indígenas, a saber, as narrativas sobre o dilúvio e sobre a passagem de Sumé pelas terras dos índios.

Em relação ao registro de Thevet, a narrativa sobre o dilúvio registrada por d'Abbeville parece ter sido adaptada para coincidir ao máximo com o relato bíblico. Talvez, por isso, tenha sido narrado apenas um dilúvio:

"Acreditamos ainda que por causa da maldade dos homens e para castigar-nos Deus fez o Dilúvio, apenas escapando um bom pai e uma boa mãe de quem descendemos todos". 253

Este registro, se comparado aos dois dilúvios descritos por Thevet, parece ter tomado emprestado das antigas versões apenas os elementos que permitiram sua

251 THEVET, André. Singularidades da França Antarctica: a que outros chamam de América. Belo Horizonte: Itatiaia; São Paulo: Edusp, 1978.

${ }^{252}$ THEVET, André. La Cosmographie Universelle. Paris, 1575. apud MÉTRAUX, Alfred. Op. Cit.

${ }^{253}$ D’ ABBEVILLE, Claude. Op. Cit. p. 60. 
aproximação com o relato bíblico, a saber, a concepção desse evento como uma punição divina aos seres humanos, presente no primeiro registro desse mito na Cosmographie:

"Ora, a razão pela qual foi feito o mar é a seguinte: como os homens viviam a seu bel prazer, gozando do que a terra produzia, ajudada pelo orvalho do céu, aconteceu que eles se esqueceram a maneira correta de se comportar, e viveram desordenadamente. ${ }^{, 254}$

"Eles caíram numa tal loucura que começaram a desprezar Monan, que então morava entre eles e os freqüentava. Monan, vendo a ingratidão dos homens, sua maldade e seu desprezo para com ele, que os tratava tão bem, afastou-se, e fez descer Tata, o fogo, que queimou e consumiu tudo o que havia na face da terra". ${ }^{255}$

E a salvação do casal do qual descende os Tupinambá, presente no segundo registro do tema do dilúvio na Cosmographie:

“Na esperança de se salvar, os dois irmãos subiram na montanha mais alta do país, e aí subiram nas árvores juntamente com as esposas (...)". ${ }^{256}$

Já se compararmos o motivo mítico que foi relacionado pelos jesuítas à passagem de São Tomé pelo Brasil presente nas Singularidades com a narrativa registrada por d'Abbeville, veremos que eles só possuem em comum o tema da partida do "profeta" que deixa as marcas de seus pés no rochedo. Na versão de d'Abbeville, como vimos, existe mais de um profeta. Estes vieram à terra dos índios, na época em que indígenas e brancos constituíam uma única nação, para instruir os homens nas leis de Deus. Durante sua estadia, os profetas ofereceram aos homens duas espadas para que eles escolhessem. As distintas escolhas determinaram a origem das diferenças entre os brancos e os índios: os últimos, ao optarem pela espada de madeira, fizeram a escolha errada já que, sem o saber, optaram pela pobreza.

${ }^{254}$ THEVET, André. La Cosmographie Universelle. Paris, 1575. apud POMPA, Cristina. Op, Cit., p. 182.

${ }^{255}$ Ibidem, p. 183.

${ }^{256}$ Ibidem, p. 186. 
É a descrença nativa nos "profetas" a partir desse episódio que determina, nessa versão, a partida dos mesmos. Por sua vez, em Thevet, há apenas um profeta. A este se atribui o início do uso do fogo e da agricultura dentre os indígenas. Nessa versão, fragmentada em duas passagens, não se menciona o motivo de sua partida:

“Após termos sido assim recepcionados, levou-nos o chefe a uma laje de cerca de 5 pés de comprimento, na qual se viam umas ranhuras que pareciam ter sido feitas por uma vara ou um bastão, e as marcas de dois pés, que os indígenas afirmam ser de seu grande Caraíba, ao qual reverenciam como os turcos a Mafoma, dizendo que foi ele quem lhes ensinou a fazer e usar o fogo, e a como plantar as raízes, a eles que antes viviam apenas de folhas e ervas, quais animais". 257

"Contam que uma vez apareceu entre eles um grande caraíba, ou seja, um profeta, que se dirigiu a uma jovem e lhe confiou uma raiz volumosa denominada jetica, semelhante ao nabo limusino, ensinando-lhe a cortá-la em fatias, plantando-as depois na terra. Assim fez a moça, e este conhecimento tem sido desde então transmitido de pai para filho até os dias de hoje. E foi tamanho o sucesso desse cultivo, que os indígenas atualmente possuem grande abundância desta raiz, quase não comendo outra coisa, pois tal alimento é para eles tão comum quanto o é para nós o pão". ${ }^{258}$

Possivelmente, o tema da partida do profeta por conta da descrença indígena tenha sido um tema inserido nesse fragmento mítico a partir do conhecimento indígena da narrativa bíblica sobre a pregação dos apóstolos por todo o mundo, difundida, principalmente, pelos missionários. No entanto, a narrativa parece conservar um núcleo comum: a vinda desse profeta implica na fundação da realidade conhecida pelo nativo.

Em Thevet, que esteve entre indígenas que viviam em uma região onde a missão ainda não havia chegado e que o processo de colonização francês ainda era recente, a realidade fundada pelo profeta ou caraíba é a agricultura e o uso do fogo culinário.

Já em d'Abbeville, que esteve no Brasil, depois de mais de meio século de missões e em um período em que a colonização do litoral brasileiro havia se

${ }^{257}$ THEVET, André. Op. Cit. p.90.

${ }^{258}$ THEVET, André. Op. Cit., p.99. 
intensificado, a realidade a ser fundada parece ser as novidades trazidas pelo branco: a pobreza material indígena, se comparada com os bens possuídos pelos europeus junto com todas as dificuldades pelas quais os índios passaram desde o advento do homem branco.

No que diz respeito à guerra vimos que o sentido desta mudou, já que houve restrições severas à prática antropofágica, tanto por parte da administração colonial quanto por parte dos jesuítas: ao mesmo tempo em que a guerra foi condenada pelos jesuítas, ela foi incentivada pelos colonos, se transformando em um instrumento da administração colonial em seu domínio sobre as populações indígenas e sobre o território brasileiro e/ ou em guerras de captura de escravos para serem trocados por bens materiais europeus, ao invés de homens que seriam sacrificados para os ancestrais míticos, como deduziu Florestan Fernandes ${ }^{259}$, ou para perpetuar o núcleo do "ser tupinambá", a vingança, como afirmaram Viveiros de Castro e Carneiro da Cunha $^{260}$.

Esse novo sentido assumido guerra parece surgir na versão da narrativa sobre sua origem registrada por d'Abbeville. O código privilegiado para a construção dessa versão parece ter sido a fala e a prática missionária em relação a essas guerras: como vimos, a guerra e, sobretudo, a prática antropofágica foram vistas em todas as fontes e em todas as análises do período, inclusive nos relatos não jesuítas, como um costume contrário à vontade do deus cristão. Dentro de uma tradição que concebia como diabólico tudo aquilo que fizesse oposição ao cristianismo, a guerra e a antropofagia foram concebidas então como hábitos instituídos pelo Diabo, que passara a dominar a América desde a partida dos profetas cristãos.

Nessa direção, a explicação sobre a origem da guerra presente no registro de d'Abbeville, deve recuar ao tema da chegada dos profetas e da sua partida. Além disso, o motivo da escolha das duas espadas - que mencionamos anteriormente parece fundar a explicação sobre por que os indígenas não conseguiam vencer a guerra contra os cristãos. Retomemos o fragmento mítico a partir desse ponto:

“Apresentaram êsses profetas ao nosso pai do qual descendemos, duas espadas, uma de madeira, outra de ferro e lhe permitiram escolher. Êle achou que a espada

\footnotetext{
${ }^{259}$ FERNANDES, Florestan. A função social da guerra na sociedade tupinambá. São Paulo: Pioneira, 1970.

${ }^{260}$ CARNEIRO DA CUNHA, Manuela L.; VIVEIROS DE CASTRO, Eduardo B.; Vingança e temporalidade: os Tupinambá. Journal de la Societe des Americanistes. Paris, v.71, p.191-208, 1985.
} 
de ferro era pesada demais e preferiu a de pau. Diante disso, o pai de quem descendestes, mais arguto, tomou a de ferro. Desde então fomos miseráveis, pois os profetas, vendo que os de nossa nação não queriam acreditar nêles, subiram para o céu, deixando as marcas de seus pés cravadas com cruzes no rochedo próximo de Potiiú, que tu viste tão bem quanto eu (disse dirigindo-se a Migan)

Depois disso surgiu entre nós a diversidade das línguas, pois antes tínhamos a mesma. De modo que [não] nos entendendo mais, massacramo-nos e comemos uns aos outros, fazendo o jogo de Jurupari". ${ }^{261}$ (grifo meu)

Os profetas que vieram instruir os indígenas na lei de Deus são os mesmos que apresentaram as espadas para os indígenas escolherem. Fazendo a opção errada, os indígenas deixaram de acreditar nesses profetas que foram embora da terra dos índios. Contudo, se os nativos tiveram motivos para desacreditarem nos profetas cristãos, por conta da ineficácia da arma escolhida, os brancos não os tinham, pois fizeram a melhor escolha. Isso explica o início da separação entre brancos e índios e o domínio de Tupã entre os primeiros em oposição ao domínio de Jurupari entre os segundos.

Dessa forma, o tema da origem da guerra em d'Abbeville, como em Léry, se relaciona ao fim do domínio de Tupã entre os indígenas, já que é depois da partida dos profetas e o início do domínio de Jurupari que os indígenas começam a falar línguas diferentes, fato que gera desentendimentos que, por sua vez, dão origem às guerras e a antropofagia.

A relação entre a diversidade de línguas com a origem da guerra talvez tenha sido realizada durante as missões como um código negociado e construído pelos missionários e pelo grupo ao qual Japi-Açu pertencia, já que, segundo a doutrina cristã, o início da diferenciação da linguagem e das raças entre os homens é explicado pela narrativa bíblica sobre a Torre de Babel:

"Em toda a Terra, havia somente uma língua, e empregavam-se as mesmas palavras. Emigrando do Oriente, os homens encontraram uma planície na terra de Chinear e nela se fixaram. Disseram uns para os outros: «Vamos fazer tijolos, e cozamo-los ao fogo.» Utilizaram o tijolo em vez da pedra, e o betume serviu-lhes de argamassa. Depois disseram: «Vamos construir uma cidade e uma torre, cujo cimo atinja os

${ }^{261}$ D’ABBEVILLE, Claude. Op. Cit. p.60-1. 
céus. Assim, havemos de tornar-os famosos para evitar que nos dispersemos por toda a superfície da terra.»O SENHOR, porém, desceu, a fim de ver a cidade e a torre que os homens estavam a edificar. E o SENHOR disse: «Eles constituem apenas um povo e falam uma única língua. Se principiaram desta maneira, coisa nenhuma os impedirá, no futuro, de realizarem todos os seus projectos. Vamos, pois, descer e confundir de tal modo a linguagem deles que não consigam compreenderse uns aos outros.» E o SENHOR dispersou-os dali por toda a superfície da Terra, $e$ suspenderam a construção da cidade. Por isso, lhe foi dado o nome de Babel, visto ter sido lá que o SENHOR confundiu a linguagem de todos os habitantes da Terra, $e$ foi também dali que o SENHOR os dispersou por toda a Terra." 262

Tanto a narrativa bíblica, quanto a versão registrada por d'Abbeville, concebem a origem da diversidade lingüística (e, assim, das contendas entre os grupos sociais) como um castigo divino aos homens que desafiaram o poder de Deus ao pretenderem alcançar o céu - um plano não acessível ao homem durante a vida ou ao não acreditar nos profetas de Deus e, assim, optarem, conforme a dicotomia cristã, por obedecerem ao Diabo.

Já na Cosmographie, a origem das diferenças entre as etnias indígenas é explicada na narrativa sobre o segundo dilúvio. Segundo essa versão, a briga entre os filhos de Sumé, Tamendoré e Ariconte, causou um grande dilúvio, do qual só sobreviveram os dois irmãos e suas esposas. Assim, a briga ocorrida antes do dilúvio fundamenta a inimizade entre os descendentes de Tamendoré (os Tupinambá) e os descendentes de Ariconte (os Temiminó). Note-se que o motivo da briga foi a zombaria feita por Ariconte das habilidades bélicas de seu irmão: ele falou que Tamendoré não era corajoso nem valente o bastante na guerra ${ }^{263}$.

Comparando-se as versões registradas por Thevet e por d'Abbeville, podemos observar uma maior influência do código cristão no registro deste último: como vimos, em d'Abbeville, os desentendimentos entre as etnias indígenas aparecem como uma consequiência da diversificação lingüística (tema tratado na Bíblia no episódio sobre a construção da Torre de Babel) que ocorreu depois da partida dos

\footnotetext{
262 Gênesis 11:1-9.

263 THEVET, André. Cosmographie Universelle. Paris, 1575. apud: MÉTRAUX, Alfred. Op. Cit., p.200-1
} 
profetas cristãos, nos quais os indígenas deixaram de acreditar depois que escolheram a espada menos eficaz.

Por sua vez, o registro de Thevet parece coincidir com a proposta de Carneiro da Cunha e Viveiros de Castro para a questão da vingança e da temporalidade entre os Tupinambá ${ }^{264}$, já que segundo esse registro, a vingança é o tema da memória da fundação da guerra: os desentendimentos entre as etnias indígenas foram fundados pela primeira dissidência entre dois irmãos, ancestrais dos indígenas, sobre as habilidades guerreiras de um dos irmãos. Todavia, esse registro não está isento das influências do código cristão.

Como observou Pompa em sua análise da representação de Monan em Thevet, possivelmente, a semelhança de Monan com o Deus do Gênesis é um produto não somente da busca que o cosmógrafo fez de algo reconhecível nas "crenças" indígenas, mas também da incorporação das características do Deus cristão à mitologia nativa ${ }^{265}$. No entanto, como foi possível observar acima, a comparação entre os mitos registrados por Thevet em meados do século XVI e as narrativas registradas por d'Abbeville no início do século XVII, demonstra que entre esses registros existem diferenças que não podem ser desprezadas.

Tudo indica que essas diferenças, presentes tanto na narrativa do dilúvio, como na versão de cada um dos outros temas míticos proferidos por Japi-Açu, foram produzidas a partir de uma releitura nativa de uma realidade muito diferente daquela dos Tupinambá que Thevet conheceu, já que, como apontamos anteriormente, os nativos do Maranhão possivelmente conheceram bem de perto o processo colonizador e as missões. Nesse sentido, acreditamos que a proximidade dos fragmentos míticos registrados por d'Abbeville com algumas passagens da Bíblia, seja o resultado da negociação simbólica entre os Tupinambá e os padres jesuítas durante as missões, que construíram, desse modo, um código compartilhado, como sugeriu Montero ${ }^{266}$.

Ao concebermos o conjunto das narrativas que compõem o discurso de JapiAçu como códigos construídos não apenas para re-fundar a realidade, a partir da

\footnotetext{
${ }^{264}$ CUNHA, Manuela M. Carneiro da; CASTRO, Eduardo B. Viveiros de. Op. Cit.

${ }^{265}$ POMPA, Cristina. Op. Cit., p.182-3.

${ }^{266}$ MONTERO, Paula. Op. Cit.
} 
“mitologia" proferida pelos missionários jesuítas, mas também para a comunicação com o outro, podemos compreender a seleção dos temas míticos realizada por JapiAçu, por ocasião do seu discurso de aceitação da proposta francesa de aliança: do acervo mitológico nativo ele escolheu os temas que tratavam da separação entre brancos e índios, e entre as etnias indígenas, ou seja, foram selecionados os motivos míticos que poderiam fundamentar, naquele momento, a aliança proposta, na medida em que a separação entre os povos pressupõe que, originalmente, esses povos constituíam uma só "nação". Esse constitui um importante aspecto a se considerar na comparação das diferenças entre os registros de Thevet e de d'Abbeville dos temas míticos comuns em suas obras.

O tema da separação entre brancos e índios e entre as etnias indígenas, tal qual ele surge na narrativa proferida por Japi-Açu parece fundar a aliança entre os indígenas do Maranhão e os franceses, uma vez que essa narrativa retoma alguns motivos bíblicos difundidos pelos jesuítas no início da missão para legitimá-la tanto para os indígenas quanto para os europeus, a saber, as narrativas bíblicas do Gênesis que serviram para fundamentar uma origem comum entre americanos e europeus e para explicar a separação entre esses povos, além da passagem sobre a pregação apostólica por todo o mundo.

Os códigos criados e compartilhados entre jesuítas e indígenas a respeito dessas narrativas parece ter fornecido os elementos necessários tanto para a difusão da mensagem cristã quanto para a re-fundação da novidade representada pela presença européia no continente americano. Esses códigos, no contexto da proposta de aliança entre franceses e indígenas, parece ter fornecido a fundamentação necessária tanto para os indígenas quanto para os padres capuchinhos.

Do lado indígena, os temas da origem comum e da posterior separação entre brancos e índios fundamenta a aliança na medida em que aponta para o fato de que índios e brancos compunham uma só "nação" nos primórdios dos tempos. Do lado dos missionários capuchinhos, as narrativas bíblicas do Gênesis que tratam da queda da humanidade, junto com a narrativa sobre a pregação apostólica por todo o mundo, fundamenta a evangelização dos indígenas e, desse modo, sua inserção dentre os europeus pela via religiosa.

Portanto, essa aliança parece representar para os nativos o retorno aos tempos primordiais que, segundo o discurso de Japi-Açu, parece ter sido a "idade de ouro" dos indígenas já que, antes da partida dos "profetas de Deus" não havia sofrimentos 
entre os índios; ao mesmo tempo em que, para os missionários capuchinhos parece representar o fim dos tempos, por intermédio da conversão dos últimos gentios.

No contexto em que o discurso de Japi-Açu foi proferido e em relação às demais narrativas, a origem das guerras inter-tribais e da antropofagia são concebidas, então, como parte das "misérias" que ocorreram com os índios depois da partida dos profetas cristãos e, sucessivamente, dos seus seguidores. Dessa forma, essa narrativa difere da versão registrada por Thevet na medida em que não é a primeira ofensa ocorrida entre os indígenas que funda a guerra, mas a descrença indígena nos profetas cristãos.

Nesse sentido, é provável que o discurso jesuíta, - que condenava a guerra e a antropofagia - junto com as intervenções desses missionários no ritual antropofágico tenham servido de base para uma re-fundação da guerra indígena, tal como sugerimos para a narrativa sobre a origem da guerra registrada por Léry. Dessa forma, as mudanças impostas pelas missões - além daquelas impostas pela administração colonial - nos rituais que compunham a guerra nativa criaram a necessidade de se refundar miticamente os ritos de guerra que sofreram intervenção missionária, já que esta última não constituía um elemento previsto pelo mito.

Como apontou De Martino, nas sociedades tradicionais é a simbologia mítico-ritual que funda a presença atuante do homem no mundo, assim como protege essa presença do risco de "não ser mais no mundo",267. Esse risco se apresentaria por intermédio dos acontecimentos não previstos miticamente. Para solucionar a crise instaurada pelo não previsto, a historicidade seria suspensa e os mecanismos míticorituais seriam acionados, para uma re-fundação mítica da realidade ${ }^{268}$ que possibilitaria a inserção de novos elementos.

Nesse sentido, a narrativa proferida por Japi-Açu pode representar também uma re-fundação mítica da nova realidade. Sob esse ponto vista, a mudança no fundamento mitológico das guerras inter-tribais - da vingança re-memorada para a miséria advinda depois da descrença nativa em Tupã - pode ser vista também como uma mudança naquilo que foi denominado o núcleo da cultura tupinambá, ou seja, a vingança: esta última, sozinha, talvez não representasse mais, naquele período,

${ }^{267}$ DE MARTINO, Ernesto. Op. Cit. Apud: POMPA, Cristina. Memórias do fim do mundo: Para uma leitura do movimento sócio-reigioso de Pau de Colher. Dissertação de Mestrado. Campinas, Unicamp, 1995. p.54

${ }^{268}$ Ibidem, p.55. 
argumento suficiente para a guerra indígena, já que como vimos, as guerras intertribais sofreram mudanças desde os primeiros contatos com os europeus.

Dessa forma, tudo indica que os fundamentos mitológicos da guerra indígena precisaram ser repensados a partir do contato com a alteridade européia. No entanto, não é possível afirmar que a versão registrada por d'Abbeville represente o modo como os nativos pensavam a guerra no período em que essa versão foi registrada, uma vez que essa narrativa, como vimos, também constituía parte de um discurso de aceitação dos termos propostos pelos franceses para a concretização de uma aliança entre indígenas e franceses. 


\section{CONCLUSÃO}

As narrativas brevemente analisadas nesse trabalho só podem ser concebidas como narrativas míticas a partir da perspectiva segundo a qual estas foram um produto de uma "cultura" criada a partir do encontro entre europeus e americanos. Assim, os elementos cristãos nela inseridos podem ser interpretados não só como um produto de uma leitura "cristã" da realidade americana, mas também como algo construído por estrangeiros e indígenas durante o contato.

A forma de difusão do cristianismo entre os indígenas parece ter ocorrido de forma distinta no contexto dos dois registros estudados por esse trabalho. No caso da narrativa presente na obra de Jean de Léry ${ }^{269}$, possivelmente a mensagem cristã foi transmitida pelos intérpretes e pelos calvinistas que fugiram da colônia de Villegagnon. Já no caso da narrativa registrada por d'Abbeville ${ }^{270}$, tudo indica que o cristianismo foi ensinado pelos missionários com os quais os indígenas tiveram contato antes de migrarem para o Maranhão.

Como vimos, a mensagem cristã transmitida pelos missionários jesuítas, opôs o cristianismo à guerra por vingança e à antropofagia, apontando, dessa forma, este costume indígena como o principal obstáculo à conversão dos indígenas. Entretanto, os missionários não se restringiram a condenar verbalmente esses hábitos, mas passaram a intervir neles no sentido de tentar evitar ou pelo menos amenizar sua realização.

O posicionamento dos franceses em relação à guerra, no contexto das duas colônias francesas no Brasil, foram muito semelhantes: condenou-se verbalmente os seu motivo - a vingança - e tentou-se proibir um dos ritos finais dessas guerras, ou seja, a antropofagia. No entanto, não houve a proibição da continuidade dessas guerras, já que, conforme se pode deduzir a partir da análise de alguns estudos e das fontes, elas eram uma fonte de mão-de-obra para as duas colônias francesas. A proibição da antropofagia e o incentivo às guerras intertribais também foram feitos pela colônia portuguesa, para conseguir escravos e para conter o perigo representado pelo indígena inimigo.

Esses posicionamentos sobre a guerra e a antropofagia tupinambá estão presentes nas narrativas que aqui analisamos, certamente representando o ponto de

\footnotetext{
${ }^{269}$ LÉRY, Jean de. Op. Cit. p. 168.

${ }^{270}$ D’ABBEVILLE, Claude. Op. Cit. p.61.
} 
vista daqueles que transcreveram esses mitos, possivelmente representando a reflexão indígena a respeito dessas práticas, a partir dos novos elementos apresentados pelo encontro com os europeus.

No caso da narrativa registrada por Jean de Léry, como vimos, esse tema foi utilizado por esse autor para realizar uma crítica à própria sociedade, a partir da concepção que o autor tinha da crença cristã e de um ponto de vista compartilhado entre ele e a maior parte dos europeus sobre a guerra por vingança e a antropofagia, a saber: esta prática se explicava pelo domínio do Diabo entre os indígenas, que nos tempos primordiais haviam se recusado a obedecer ao Deus cristão.

Esse tema se repete na versão desse mito registrada por D'Abbeville: igualmente, segundo essa versão, a guerra e a antropofagia surgiram entre os índios depois dos profetas do Deus cristão terem abandonado os indígenas que se recusavam a obedecer-lhes. Depois da partida desses profetas, surgiu dentre os índios a diversidade lingüística, que primeiro causou os desentendimentos entre os índios, depois gerou a guerra.

A repetição desse tema pode ser explicada tanto pela circulação dos relatos e das idéias sobre os americanos na Europa, quanto pela oposição européia à antropofagia indígena: em ambos os casos, a antropofagia e a guerra por vingança foram condenadas a partir do código cristão.

Portanto, como indicamos no desenvolvimento desse trabalho, esses registros podem ser lidos também como uma re-fundação tupinambá da prática da guerra, a partir da perspectiva sobre a relação entre mito, rito e história fornecida pelo estudo de alguns autores, segundo a qual o contato teria trazido para as populações não européias - e que, portanto, não compartilham do ponto de vista histórico desenvolvido no Ocidente pelo cristianismo - novidades a serem assimiladas pelos mecanismos mítico-rituais dessas sociedades.

Nesse sentido, a opinião dos europeus (principalmente dos missionários) sobre a guerra e a antropofagia foi inserida nos mitos de fundação desses costumes, tanto a partir do conhecimento que os indígenas tinham dessa opinião quanto a partir da intervenção européia nos ritos que compunham o "ciclo da guerra".

Por fim, como apontou John Monteiro em sua análise do mito da espada de madeira, esses registros podem ser lidos também como uma resposta dada pelas lideranças indígenas às condições desfavoráveis impostas pela colonização, a partir de instrumentos dados pelos colonizadores, organizando-se assim, uma resistência 
que não se limitou ao apego às próprias tradições, mas que se fortalecia com a abertura às novidades trazidas pelo outro ${ }^{271}$.

${ }^{271}$ MONTEIRO, John M. A espada de madeira. In: PINTO, Zélio A. Cadernos Paulistas: histórias e personagens. São Paulo: SENAC; IMESP, 2002. p.29-30. 


\section{FONTES}

D’ABBEVILLE, Claude. História da missão dos padres capuchinhos na Ilha do Maranhão e terras circunvizinhas. Belo Horizonte: Itatiaia/ São Paulo: Edusp, 1975.

D'ÉVREUX, Yves. Viagem ao norte pelo padre Ivo d'Éverux. Rio de Janeiro: Freitas Bastos, 1929.

LEITE, Serafim (S.I.) Cartas dos primeiros jesuítas do Brasil, V.1. São Paulo:

Comissão do IV centenário da cidade de São Paulo. São Paulo: 1954.

LEITE, Serafim (S.I.) Cartas dos primeiros jesuítas do Brasil, V.2. São Paulo:

Comissão do IV centenário da cidade de São Paulo. São Paulo: 1954.

LEITE, Serafim (S.I.) Cartas dos primeiros jesuítas do Brasil, V.3. São Paulo:

Comissão do IV centenário da cidade de São Paulo. São Paulo: 1954.

LÉRY, Jean de. Viagem à terra do Brasil. Belo Horizonte: Itatiaia/ São Paulo: Edusp, 1980

THEVET, André (1502-1590). Singularidades da França Antarctica : a que outros chamam de América. São Paulo : Companhia Editora Nacional, 1944.

THEVET, André. Cosmographie Universelle. Paris: Guillaume Chaudiere, 1575.

VIEIRA, Antonio. Cartas do Brasil. São Paulo: Hedra, 2003. 


\section{REFERÊNCIAS BIBLIOGRÁFICAS}

AGNOLIN, Adone. "Jesuítas e selvagens no encontro catequético no século XVI". Revista de História. São Paulo, n.144, 2001. p.19-71

- O Sabor Antropofágico do Saber Antropológico: alteridade e identidade no caso Tupinambá. São Paulo: Associação Editorial Humanitas, 2005.

CARNEIRO DA CUNHA, Manuela L. História dos Índios do Brasil. São Paulo: Cia das Letras; Secretaria Municipal de Cultura; FAPESP, 1992.

CARNEIRO DA CUNHA, Manuela L.; VIVEIROS DE CASTRO, Eduardo B.; Vingança e temporalidade: os Tupinambá. Journal de la Societe des Americanistes. Paris, v.71, p.191-208, 1985.

CERTEAU, Michel de. A escrita da história. Rio de Janeiro: Forense Universitária, 2002.

CLASTRES, Hélène. Terra sem mal. O profetismo tupi-guarani. São Paulo: Brasilense, 1978.

FAUSTO, Carlos. Da inimizade. Forma e simbolismo da guerra indígena. In: NOVAES, Adauto (org.). A outra margem do ocidente. Brasília-DF: MINC-FUNARTE; São Paulo: Companhia das Letras, 1999, p.266.

FERNANDES, Florestan. "O mundo do índio e sua crise". In: A investigação etnológica no Brasil e outros ensaios. Petrópolis: Vozes, 1975.

A função social da guerra na sociedade tupinambá. São Paulo: Pioneira/ Edusp, 1970.

Notas sobre a educação na sociedade tupinambá. São Paulo:

CRPE, 1964.

- Organização social dos tupinambá. São Paulo: Hucitec; Brasília:

Ed. da UnB, 1989

GRUZINSKI, Serge; BERNAND, Carmem. De la idolatria: una arqueologia de las ciências religiosas. México: Fondo de Cultura Econômica, 1992.

HOLLANDA, Sérgio Buarque de; CAMPOS, Pedro Moacyr. História geral da civilização brasileira. T.1 v.1. A época colonial: do Descobrimento à expansão territorial São Paulo: Difusão Européia do Livro, 1960.

LESTRINGANT, Frank. Le Huguenot et le Sauvage. Paris: Aux Amateurs de Livres, 1990. . O canibal: grandeza e de cadência. Brasília : UnB, 1997. . Mitológicas: a invenção do Brasil. Revista USP A outra conquista: os huguenotes no Brasil. In: NOVAES, Adauto 
(org.) A descoberta do homem e do mundo. Brasília: MINC-FUNARTE; São Paulo: Companhia das Letras, 1998.

À espera do outro. Nota sobre a antropologia da Renascença. U desafio ao espírito de sistema. In: NOVAES, Adauto. A outra margem do Ocidente. Brasília-DF, MINC - FUNARTE, São Paulo: Companhia das Letras, 1999.

LÉVI-STRAUSS, Claude. Mito e significado. Lisboa: Edições 70, 1997. . O cru e o cozido. Mitológicas v.1. São Paulo: Cosac \& Naify, 2004. . Do mel às cinzas. Mitológicas, v.2. São Paulo: Cosac \& Naify, 2004. A origem dos modos à mesa. Mitológicas, v.3. São Paulo: Cosac \& Naify, 2004.

Editores, s.d.

MASSENZIO, M. História das religiões na cultura moderna. São Paulo: Hedra, 2005.

MAZZOLENI, Gilberto. O Planeta Cultural: Para uma antropologia histórica. São Paulo: Edusp, 1992.

MÉTRAUX, Alfred. A religião dos tupinambás. São Paulo: Ed.Nacional/ Edusp, 1979.

MONTEIRO, John. A espada de madeira. IN: PINTO, Zélio Alves (org.). Cadernos Paulistas: história e personagens. São Paulo: Imesp, 2002. p. 28-31.

MONTEIRO, John. Negros da terra: índios e bandeirantes nas origens de São Paulo. São Paulo: Companhia das Letras, 1994.

MONTERO, Paula (org.). Deus na aldeia: missionários, índios e mediação cultural. São Paulo: Globo, 2006.

PAGDEN, Anthony. The fall of natural man. The American Indian and the origins of comparative ethnology. Cambridge: Cambridge University Press, 1982.

PERRONE-MOISÉS, Beatriz. Relações Preciosas: franceses e ameríndios no século XVII. Tese. Orientadora: CUNHA, Manuela Carneiro da. Universidade de São Paulo, jul./1996.

PERRONE-MOISÉS, Leila. “Alegres Trópicos: Gonneville, Thevet e Léry. Revista USP, n.30, São Paulo: USP, jun.-ago. 1996.

POMPA, C. Religião como tradução: missionários, Tupi e Tapuia no Brasil colonial. Bauru, 2003.

POMPA, Cristina. Memórias do fim do mundo: Para uma leitura do movimento sócio 
religioso de Pau de Colher. Dissertação de Mestrado. Campinas, Unicamp, 1995. p.54.

RAMINELLI, Ronald. Imagens da colonização. A representação do índio de Caminha a Vieira. São Paulo: Edusp/ Fapesp; Rio de Janeiro: Jorge Zahar, 1996.

. Ilhas de História. Rio de Janeiro: Jorge Zahar ed., 1990.

SCHADEN, Egon. A mitologia heróica de tribos indígenas do Brasil. Rio de Janeiro: MEC, 1959.

Aculturação indígena. São Paulo: Livraria Pioneira Editora/ Edusp, 1969.

SOUZA, Laura de Mello e. Inferno Atlântico. Demonologia e colonização. São Paulo: Companhia das Letras, 1986.

VAINFAS, Ronaldo. A heresia dos índios. Catolicismo e rebeldia no Brasil colonial. São Paulo: Companhia das Letras, 1995.

VERNANT, Jean Pierre. Entre mito e política. São Paulo: Edusp, 2001.

. Mito e pensamento entre os gregos. Estudos de psicologia histórica. Rio de Janeiro: Paz e Terra, 1990.

VIVEIROS DE CASTRO, Eduardo B. A inconstância da alma selvagem e outros ensaios de antropologia. São Paulo: Cosac \& Naify, 2002. 